
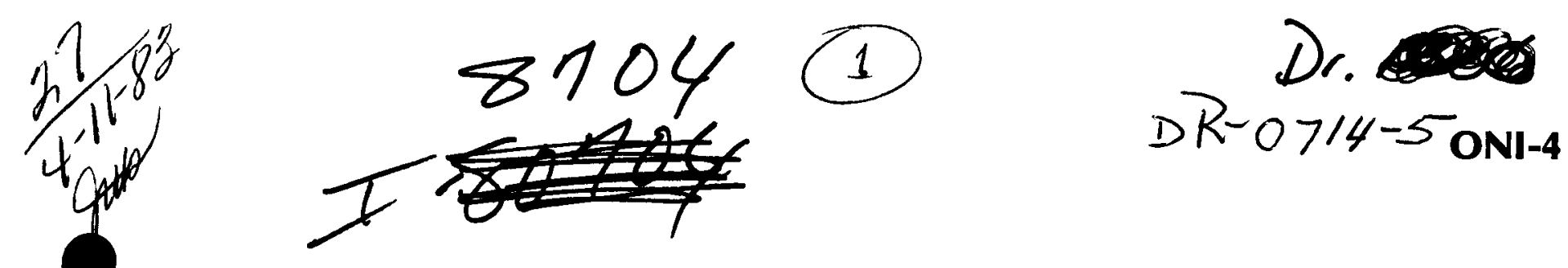

Limits on the Thermal Energy Release
From Radioactive Wastes in a Mined Geologic Repository

Technical Report

March 1983

Julia A. Scott

Office of NWTS Integration Battelle Memorial Institute Columbus, OH 43201 


\section{DISCLAIMER}

This report was prepared as an account of work sponsored by an agency of the United States Government. Neither the United States Government nor any agency Thereof, nor any of their employees, makes any warranty, express or implied, or assumes any legal liability or responsibility for the accuracy, completeness, or usefulness of any information, apparatus, product, or process disclosed, or represents that its use would not infringe privately owned rights. Reference herein to any specific commercial product, process, or service by trade name, trademark, manufacturer, or otherwise does not necessarily constitute or imply its endorsement, recommendation, or favoring by the United States Government or any agency thereof. The views and opinions of authors expressed herein do not necessarily state or reflect those of the United States Government or any agency thereof. 


\section{DISCLAIMER}

Portions of this document may be illegible in electronic image products. Images are produced from the best available original document. 


\section{BIBLIOGRAPHIC DATA}

Scott, Julia A., 1983. Limits on the Thermal Energy Release From Radioactive Wastes in a Mined Geologic Repository, ONI-4, Office of NWTS Integration, Battelle Memorial Institute, Columbus, $\mathrm{OH}$.

\section{NOTICE}

This report was prepared as an account of work sponsored by an agency of the United States Government. Neither the United States Government nor any agency thereof, nor any of their employees, makes any warranty, express or implied, or assumes any legal liability or responsibility for the accuracy, completeness, or usefulness of any information, apparatus, product, or process disclosed, or represents that its use would not infringe privately owned rights. Reference herein to any specific commercial product, process, or service by trade name, trademark, manufacturer, or otherwise, does not necessarily constitute or imply its endorsement, recommendation, or favoring by the United States Government or any agency thereof. The views and opinions of authors expressed herein do not necessarily state or reflect those of the United States Government or any agency thereof. 
ONI --4

DE83 009739

\title{
Limits on the Thermal Energy Release From Radioactive Wastes in a Mined Geologic Repository
}

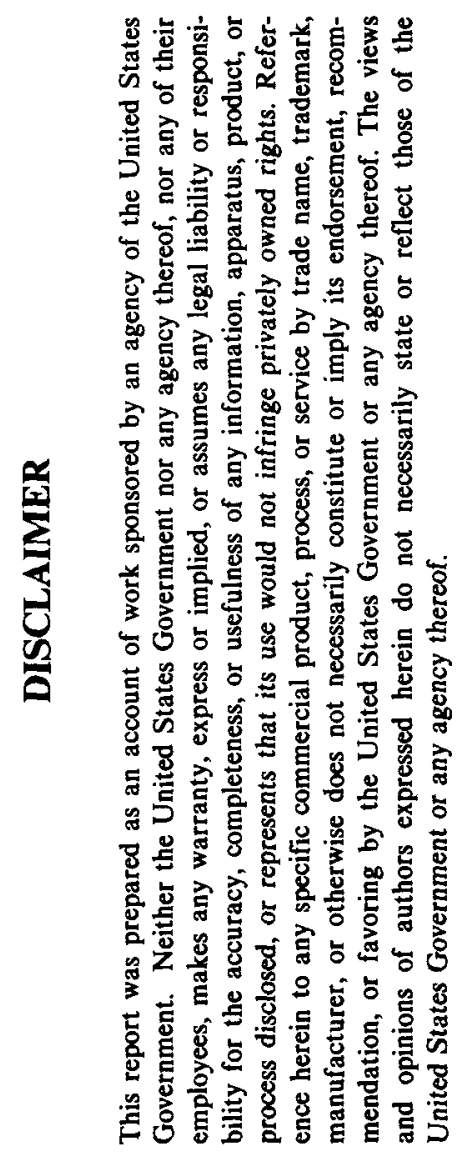

\author{
Technical Report
}

March 1983

Julia A. Scott

PORTIONS OF THIS RITCE

It has been reprodyced from the possible availability.

Office of NWTS

Battelle Memorial Institute

Columbus, OH 43201

The content of this report is effective as of June 1982. This report was prepared by Battelle Project Management Division, Office of NWTS Integration under Contract No. DE-AC06-76-RLO1830-ONI with the U.S. Department of Energy. 
ABSTRACT

The thermal-energy release of nuclear wastes is a major factor in the design of geologic repositories. Thermal limits need to be placed on various aspects of the geologic waste-disposal system to avoid or retard the degradation of repository performance because of increased temperatures. The thermal limits in current use today are summarized in this report. These limits are placed in a hierarchical structure of thermal criteria consistent with the failure mechanism they are trying to prevent.

The thermal-criteria hierarchy is used to evaluate the thermal performance of a sample repository design. The design consists of disassembled BWR spent fuel, aged 10 years, close packed in a carbon steel canister with $15 \mathrm{~cm}$ of crushed salt backfill. The medium is bedded salt. The most-restrictive temperature for this design is the spent-fuel centerline temperature limit of $300 \mathrm{C}$. A sensitivity study on the effects of additional cooling prior to disposal on repository thermal limits and design is performed. 
-

- 
Table of Contents

Page

Executive Summary. . . . . . . . . . . . . . 1

Chapter

1. Introduction ................ 21

1.1 The Need for Thermal Criteria......... 21

1.2 The Mined Geologic Disposal System. . . . . . 24

1.3 Waste Types and Sources . . . . . . . . 30

1.4 Report Organization . . . . . . . . 34

2. Literature Review. . . . . . . . . . . . 35

2.1 Very Near Field............... 35

2.2 Near Field. . . . . . . . . . . 44

2.3 Far field . . . . . . . . . . . 50

3. A Hierarchy of Thermal Criteria. . . . . . . . 59

3.1 An Overview ............. 59

3.2 Description of the Thermal Criteria

Hierarchy . . . . . . . . . . . 66

3.2.1 Waste Package System . . . . . . . . 73

3.2.2 Repository System. . . . . ..... 96

3.2.3 Site System. ............. 105

4. Application and Impacts of the Thermal Criteria

Hierarchy. . . . . . . . . . . . . . . . 119

4.1 Application of the Thermal Criteria

Hierarchy ................. 119

4.2 Impacts of Various Alternatives ........ 130

5. Conclusion and Recommendations . . . . . . . . 145 


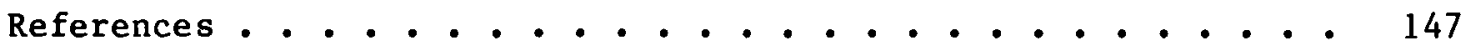

Appendices

Appendix A . . . . . . . . . . . . . . . . . . . 153

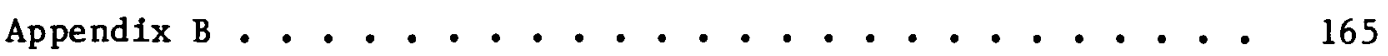


List of Tables

Table

Page

ES-1. Summary of Thermal Criteria and Limits for the Disposal of Radioactive Waste in Geologic Repositories . . . . . 9

ES-2. Repository Characteristics. . . . . . . . . 16

ES-3. A Partial Set of Restrictive Temperatures for the Repository Configuration Shown in Table ES-2. . . . . 18

2-1. Recommended Maximum Temperatures for the Waste Form. . . . . . . . . . . . 37

2-2. Recommended Maximum Canister Temperatures . . . . . . 42

2-3. Recommended Maximum Backfill Temperatures ....... 43

2-4. Recommended Maximum Media Temperatures. ........ 45

2-5. Recommended Permissible Amounts of Room Closure in Salt . . . . . . . . . . . . 46

2-6. Recommended Maximum Media Strength-to-Stress (s/s) Ratios................ 47

2-7. Recommended Average Waste Emplacement Density, kW/acre . . . . . . . . . . . . . 4 48

2-8. Recommended Maximum Working Temperature . . . . . . 49

2-9. Recommended Maximum Strength-to-Stress Ratio. . . . . 50

2-10. Recommended Maximum Vertical Displacement . . . . . 52

2-11. Recommended Shaft and Borehole Constraints. . . . . . 54

2-12. Recommended Maximum Surface Temperature Rise. . . . . 54

2-13. Recommended Hydrologic Constraints. . . . . . . 56

2-14. Recommended Maximum Media Temperatures for Geochemical Stability .............. 57 
2-15. Recommended Average Waste Emplacement Density, kW/acre. .

3-1. Recommended Maximum Waste Form Temperatures

Based on Chemical Composition, C. . . . . . . . . . .

3-2. Recommended Maximum Waste Form Temperature

Based on Volatilization ............ 77

3-3. Recommended Maximum Waste Form Temperatures

Based on Physical Integrity, C. . . . . . . . 77

3-4. Recommended Maximum Canister Temperatures

Based on Physical Integrity, C. . . . . . . . . 89

3-5. Recommended Maximum Backfill Temperatures

Based on Physical and Chemical Integrity, C . . . . .

3-6. Recommended Maximum Waste Form Temperature

Based on Internal Pressurization, C . . . . . . . .

3-7. Recommended Maximum Air Temperature

Based on Safe Working Conditions, C . . . . . . . . 97

3-8. Recommended Maximum Rock Surface Temperature, C . . . . 97

3-9. Recommended Strength-to-Stress Ratios

Based on Room Stability . . . . . . . . . . 97

3-10. Recommended Percentage of Room Closure

Based on Room Stability . . . . . . . . . . 97

3-11. Recommended Strength-to-Stress Ratios

Based on Pillar Stability . . . . . . . . . . 97

3-12. Recommended Maximum Media Temperatures

Based on Retrievability . . . . . . . . . . . . .

3-13. Recommended Minimum Strength-to-Stress Ratios

Based on Physical Integrity . . . . . . . . . . 107

3-14. Recommended Maximum Vertical Displacement, m. . . . . 107

3-15. Recommended Maximum Extent of Perturbed

Fissure Zone. . . . . . . . . ..... 107

3-16. Recommended Temperature Rise at the Surface

Based on Environmental Concerns . . . . . . . . 107

3-17. Recommended Temperature Rise in Neighboring

Aquifers Based on Environmental Concerns. . . . . . . 
3-18. Recommended Maximum Media Temperatures

Based on Geochemical Stability, C . . . . . . . .

3-19. Recommended Maximum Temperatures

Based on Sorption Properties, C . . . . . . . . .

4-1. Comparison of Thermal - Thermomechanical Limits Chosen by the Management of Commercially Generated Radioactive Waste (U.S. Department of Energy, 1980), the Westinghouse Engineered Waste Package Design Studies (Westinghouse, 1983), and the Areal Thermal Loading Recommendations for Nuclear Waste Repositories in Salt (Russe11, 1977). . .

4-2. Repository Characteristics. . . . . . . . .

4-3. A Partial Set of Restrictive Temperatures for the Repository Configuration Shown in Table 4-2......

4-4. Assumed Thermal Conductivities, Emissivities, and Heat Capacities . . . . . . . . . . . .

4-5. Repository Characteristics. . . . . . . . .

4-6. Canister Load and Spacing Variations in the Repository Configuration of Table 4-2 . . . . . . 
List of Figures

Figure

Page

ES-1. Hierarchy of a Mined Geologic Disposal System . . . . . 3

ES-2. Hierarchy of Geologic System Limits . . . . . . . 7

ES-3. Results of the Thermal Analysis of the Example

Repository Configuration. . . . . . . . . . 19

1-1. Artist's Concept of a Geologic Repository and its Support Facilities.............. 25

1-2. Schematic Design of a Waste Package for Spent Fuel. . . 26

1-3. Geologic Formations Being Investigated as Possible Host Media . . . . . . . . . . . . 28

1-4. Regions of Interest for Terminal Storage of Nuclear Waste... . . . . . . . 29

1-5. Typical PWR Fuel Rod................. 31

1-6. PWR Fuel Assembly ................ 32

2-1. Schematic Cross Section of a Repository in Grantic Rock Showing Zones of Potential Fracturing. . . . . . 51

3-1. Hierarchy of Objectives, Requirements, Criteria, and Specifications..................

3-2. A Plausible Hierarchical Structure of the Geologic Repository According to 10 CFR Part 60. . . . . .

3-3. Conceptual Structure of the Nuclear Waste Disposal system . . . . . . . . . . . 65

3-4. A Hierarchy of a Mined Geologic Disposal System . . . . 69

3-5. A Hierarchy of Functions for a Mined Geologic Disposal System. . . . . . . . . . . 
3-6. Hierarchy of Waste Form Limits. . . . . . . . . 77

3-7. Maximum Allowable Temperature to Avoid Rupture

of Fuel Rod Clad by Internal Pressure . . . . . . . . 82

3-8. Maximum Allowable Temperature for Spent

Fuel Storage at Constant Temperature. . . . . . . . 84

3-9. Decay Heat and Fuel Cladding Temperature as

a Function of Storage Time. . . . . . . . . . 85

3-10. Accumulation of Creep Damage for Various

Starting Temperatures . . . . . . . . . . 86

3-11. Hierarchy of Containment System Limits. . . . . . . 89

3-12. The Estimated Temperature Dependency of

Nickel Alloy Corrosion in Oxic Brine and

Anoxic Seawater . . . . . . . . . . . . 94

3-13. Temperature Dependency of Commercially Pure Titanium

Corrosion in Oxic Brine and Anoxic Seawater . . . . . 95

3-14. Hierarchy of Waste Handling System Limits . . . . . . 97

3-15. Comparison of Peak Floor Temperatures . . . . . . 100

3-16. Hierarchy of Sealing System Limits. . . . . . . . 104

3-17. Hierarchy of Geologic System Limits . . . . . . . 107

3-18. Hierarchy of Hydrologic System Limits . . . . . . . 111

3-19. Migration Speeds per Unit Temperature Gradient

3-20. Hierarchy of Geochemical System Limits. . . . . . . 116

4-1. Canister Configuration Used in ARRAYF . . . . . . . 124

4-2. Room and Pillar Geometry. ............ 126

4-3. Radial Temperature Distribution of

4-4. Variation of Spent Fuel Centerline Temperature

4-5. Radial Temperature Distribution of Spent

Fuel Waste Package. . . . . . . . . . . . . . 
4-6. An Hour-Glass View of the Interaction of the Thermal Criteria and the Design Options . . . . . .

4-7. Variation of Spent Fuel Centerline Temperature With Time for the Repository Configuration in

Table 4-2 . . . . . . . . . . . . . . .

4-8. Effect of Spent Fuel Age on Repository Capacities for the Once-Through Cycle and 2,000-Acre Repositories. . .

4-9. Radial Temperature Distribution of Spent Fuel Waste Package . . . . . . . . . . . . . .

4-10. Variation of Spent Fuel Centerline Temperature With Time After Emplacement . . . . . . . . . 140

4-11. Maximum Amount of BWR Spent Fuel, Cooled 10 Years, That Can Be Placed in a Waste Package Without Violating the Spent Fuel Centerline Temperature Limit . . . . .

4-12. Maximum Amount of BWR Spent Fuel, Cooled 100 Years, That Can Be Placed in a Waste Package Without Violating the Spent Fuel Centerline Temperature Limit . . . . .

B-1 Canister Layouts for Geologic Dry Well and Subseabed Repositories. . . . . . . . . . . 168

B-2 Vertical Finite Concentric Waste Cylinders Filled With an Annular Heat Source, Buried a Finite Distance From the Earth's Surface in the $x=0$ Plane. .

B-3 Vertical Finite Cylindrical Heat Sources Buried a Finite Distance From the Earth's Surface in Triangular or Square Arrays. . . . . . . . . . . . . . . 
EXECUTIVE SUMMARY

\section{Background}

Many of the technical uncertainties associated with the disposal of nuclear waste in mined geologic repositories are related to the thermal energy released by the emplaced waste and its effect on the repository system. As the heat generated by the emplaced waste migrates from the waste form through the canister and emplacement area into the host formation and through the overlying rock, it will have definite impacts on the integrity and the potential retrievability of the waste packages, the stability of the rooms and pillars, the integrity of the host rock, surrounding rock, and any overlying aquifers, the long term uplift and subsidence of the overlying rock, and ultimately the habitability of the biosphere.

Because of these effects, quite a few thermal 1imits have been suggested for the various aspects of the geologic disposal system, such as the waste form, canister, and host formation. Unfortunately, these thermal limits are currently scattered through the 1iterature and there is a need for centralizing this information.

To help alleviate this problem, a survey of the literature was undertaken to determine the thermal limits in current use. In reviewing the literature, the potential ways in which a repository could fail 
because of increased temperatures were identified. Thermal limits have been suggested for a subset of these fallure mechanisms in order to prevent their occurrence. These thermal limits were also identified in the literature review.

Thermal Criteria Hierarchy

By identifying the various ways in which thermal energy released by nuclear waste can cause a repository to fail, a set of thermal criteria can be developed. It is then possible to arrange the thermal criteria into a hierarchical structure in order to provide a systematic approach to understanding the effects of thermal energy on the overall waste disposal system.

The first step in this process is to define the mined geologic disposal system. Figure ES-1 shows the components of the mined geologic disposal system, their definitions and functions, as they relate to the thermal energy released by the emplaced waste. As can be seen from Figure ES-1, and inferred from the above statement, not all aspects of a geologic disposal system are shown. Those which are not significantly affected by increased temperatures, such as the rock handling system, were not included.

In order for any part of the mined geologic system shown in Figure ES-1 to operate successfully, the systems in the lower levels must successfully complete their assigned functions. The functions required by a higher order system, therefore, will appear as constraints on the lower order systems. Knowing the functions each part of the waste disposal system must perform, it is possible to place constraints on them 


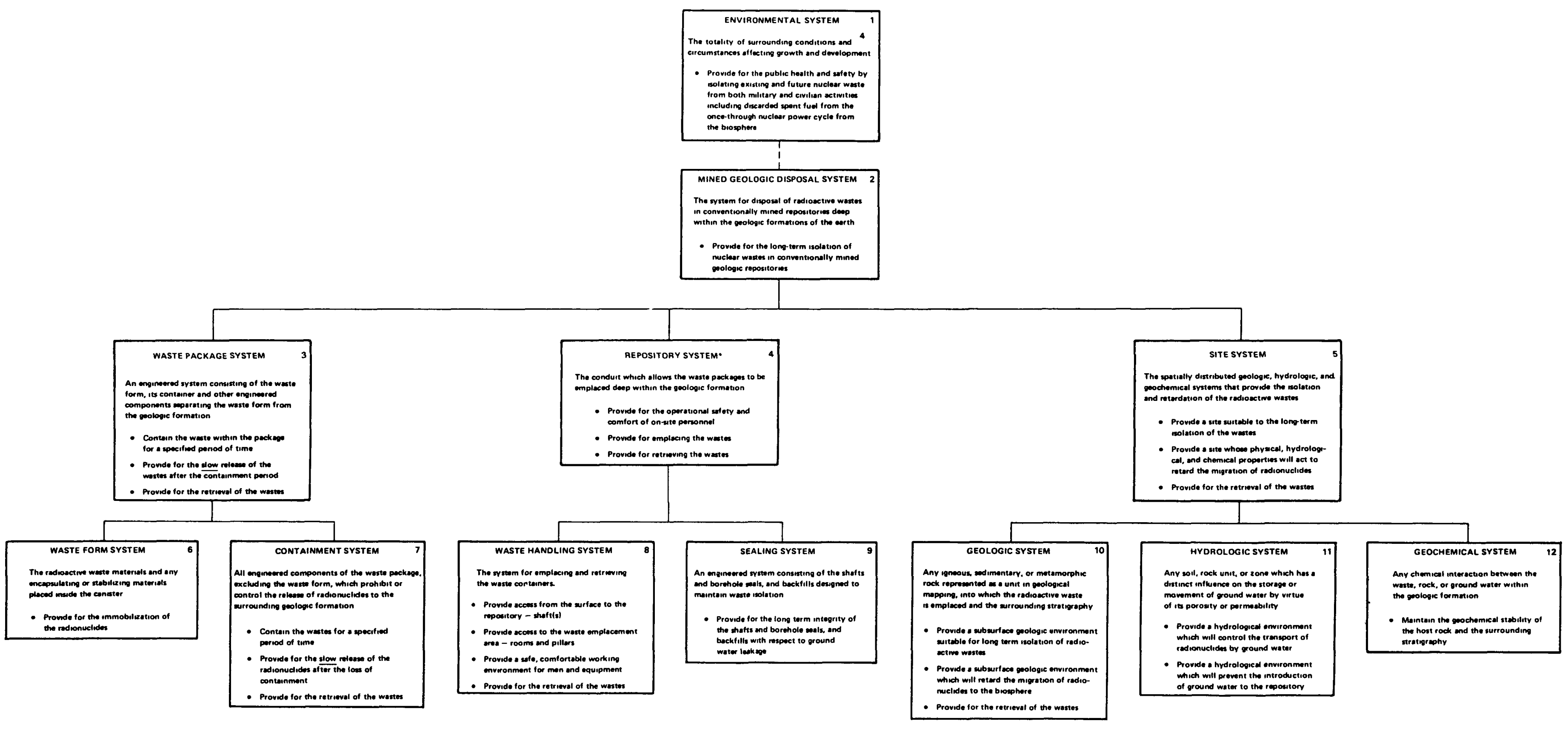

FIGURE ES-1. HIERARCHY OF A MINED GEOLOGIC DISPOSAL SYSTEM

*Not all repository subsystems are shown. 
with regard to their tolerance to the heat generated by the emplaced waste. Each of the lowest order systems in Figure ES-1, i.e., Items 6 through 12, can be further expanded to include the thermal criteria, and the thermal limits which apply to each system.

\section{Geologic System Hierarchy}

As an example of how Items 6 through 12 of Figure ES-1 can be expanded, Figure ES-2 shows the geologic system, Item 10 of Figure ES-1, in more detail and the thermal criteria that apply to it. The uppermost entry in Figure ES-2 specifies the component of the geologic disposal system under consideration. The second level in the hierarchy, Items 2 through 4 of Figure ES-2, 1ists the thermal criteria, as developed from the possible ways this particular component of the waste disposal system could fail because of the thermal energy release. The last layer in the hierarchy lists the thermal limits which have been recommended to satisfy the thermal criteria.

In the geologic system, Figure ES-2, four potentially adverse effects of the thermal energy release were identified. These are the loss of physical integrity through shear failure in the rock mass because of thermally induced changes in its state of stress, excessive vertical deformations on the surface resulting from the thermal expansion of the rock mass, the creation of an excessive perturbed fissure zone (also due to the thermal expansion of the rock mass), and an excessive ground surface temperature rise. The first three potential failure modes in the geologic system have the capability to directly alter the performance of the geologic system, while the last failure 
mode, an excessive ground surface temperature rise, may be environmentally unacceptable. The thermal criterion for each of these fallure modes is shown in the second level of the hierarchy in Figure ES-2.

The thermal limits suggested for each thermal criterion are shown in the last level of the geologic system hierarchy. Only the limit on the ground surface temperature rise is actually expressed as a temperature. The remaining thermal limits for the geologic system are derived from the thermomechanical effects of the thermal energy release on the rock mass.

Summary of the Thermal Criteria and Limits

A summary of the thermal criteria and limits that apply to the mined geologic disposal of radioactive waste is presented in Table ES-1. These thermal criteria and limits correspond to the lower two levels in the waste form system, containment system, waste handling system, sealing system, geologic system, hydrologic system, and geochemical system hierarchies.

Reading Table ES-1 from left to right, the first column identifies the system to which the thermal criteria and limits apply. These systems are the same as those shown in the lowest level in Figure ES-1, i.e., the waste form, containment, waste handling, sealing, geologic, hydrologic, and geochemical systems. The second column lists the thermal criteria that have been developed for that particular system. In any system there may be a series of alternatives, such as bedded salt or basalt in the geologic system. These alternatives appear in the third column. Finally, the last column identifies the precise manner in 


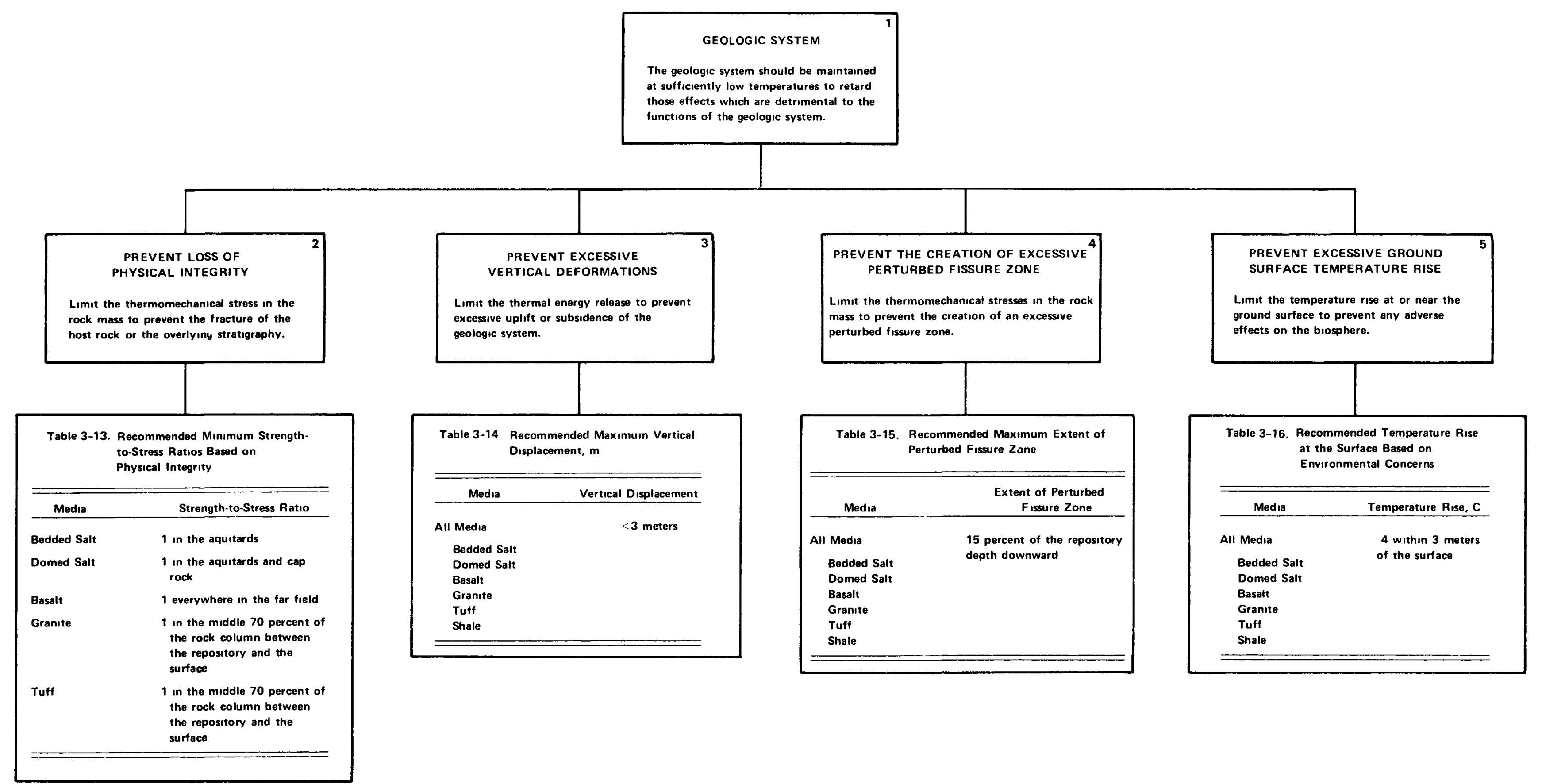

FIGURE ES-2. HIERARCHY OF GEOLOGIC SYSTEM LIMITS 
TABLE ES-1. SUMMARY OF THERMAL CRITERIA AND LIMITS FOR THE DISPOSAL OF RADIOACTIVE WASTES IN GEOLOGIC REPOSITORIES

\begin{tabular}{|c|c|c|c|c|}
\hline $\begin{array}{l}\text { Applicable } \\
\text { System }\end{array}$ & Thermal Criterıa & Alternative & Limit & Failure Mechanism \\
\hline \multirow{5}{*}{ 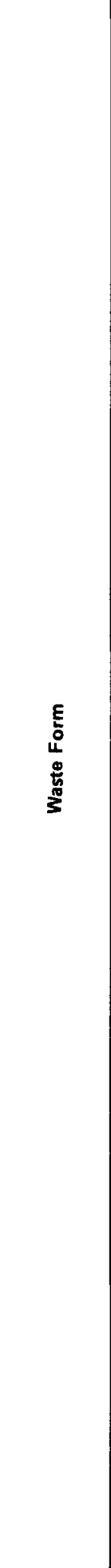 } & $\begin{array}{l}\text { PREVENT ALTERATION OF } \\
\text { CHEMICAL COMPOSITION } \\
\text { Limit the temperature of the waste form to } \\
\text { less than that required to cause changes in } \\
\text { the chemical composition of the waste form }\end{array}$ & $\begin{array}{l}\text { Spent fuel } \\
\text { Spent fuel } \\
\text { Borosilicate } \\
\text { glass HLW } \\
\text { Borosilicate } \\
\text { glass HLW } \\
\text { Thermosetting or } \\
\text { urea } \\
\text { formaldehyde } \\
\text { resins TRU }\end{array}$ & 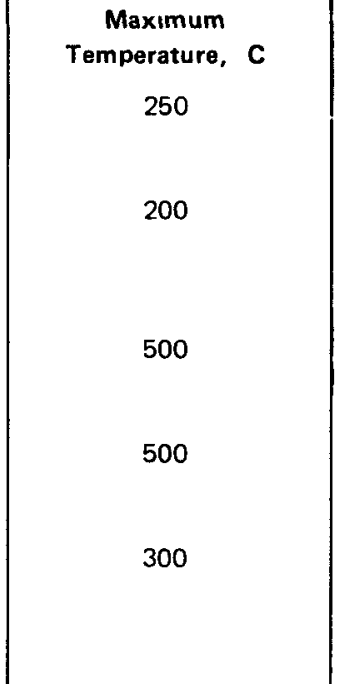 & $\begin{array}{l}\text { Oxidation of ceramic } \\
\text { fuel } \mathrm{UO}_{2} \mathrm{U}_{3} \mathrm{O}_{8} \\
\text { Degradation of protective } \\
\text { oxide film on } \\
\text { Zircaloy clad } \\
\text { Softening of glass } \\
\text { Transition } \\
\text { Decomposition of } \\
\text { waste form }\end{array}$ \\
\hline & $\begin{array}{l}\text { PREVENT COMBUSTION } \\
\text { Limit the temperature of the waste form to } \\
\text { less than that required for combustion of } \\
\text { the waste form }\end{array}$ & & & Combustion \\
\hline & $\begin{array}{l}\text { PREVENT LOSS OF } \\
\text { PHYSICAL INTEGRITY } \\
\text { Limit the temperature of the waste form to } \\
\text { less than that required to cause structural } \\
\text { changes in the waste form }\end{array}$ & $\begin{array}{l}\text { Spent fuel } \\
\text { Spent fuel } \\
\text { Spent fuel } \\
\text { Borosilicate } \\
\text { glass HLW } \\
\text { Borosilicate } \\
\text { glass HLW } \\
\text { Cement TRU }\end{array}$ & $\begin{array}{c}\text { Maxımum Temperature, c| } \\
390 \\
380 \\
300 \\
500 \\
375 \\
500-800 \\
150\end{array}$ & $\begin{array}{l}\text { Rupture of clad by } \\
\text { Internal pressure } \\
\text { Stress-rupture of the } \\
\text { clad } \\
\text { Stress-corrosion } \\
\text { cracking of clad } \\
\text { Devitrification } \\
\text { Cracking of } \\
\text { waste glass } \\
\text { Microcracking }\end{array}$ \\
\hline & $\begin{array}{l}\text { PREVENT VOLATILIZATION } \\
\text { Limit the temperature of the waste form to } \\
\text { less than that required for volatilization of } \\
\text { the waste form The resulting accumulation } \\
\text { of gases could lead to explosive conditions }\end{array}$ & Calcıne HLW & $\begin{array}{c}\text { Maxımum Temperature, c } \\
700\end{array}$ & Cesium volatility \\
\hline & $\begin{array}{l}\text { PREVENT SPONTANEOUS } \\
\text { IGNITION OF GASES } \\
\text { Limit the temperature to less than that } \\
\text { required for spontaneous ignition of } \\
\text { generated gases }\end{array}$ & & & $\begin{array}{l}\text { Spontaneous ignition of } \\
\text { gases }\end{array}$ \\
\hline
\end{tabular}

Use of Table Reads left to right, example The waste form can fall through changes in its original composition which for spent fuel can occur above $250 \mathrm{C}$ due to the oxidation of the ceramic fuel from $\mathrm{UO}_{2}$ to $\mathrm{U}_{3} \mathrm{O}_{8}$ 
TABLE ES-1. (Continued)

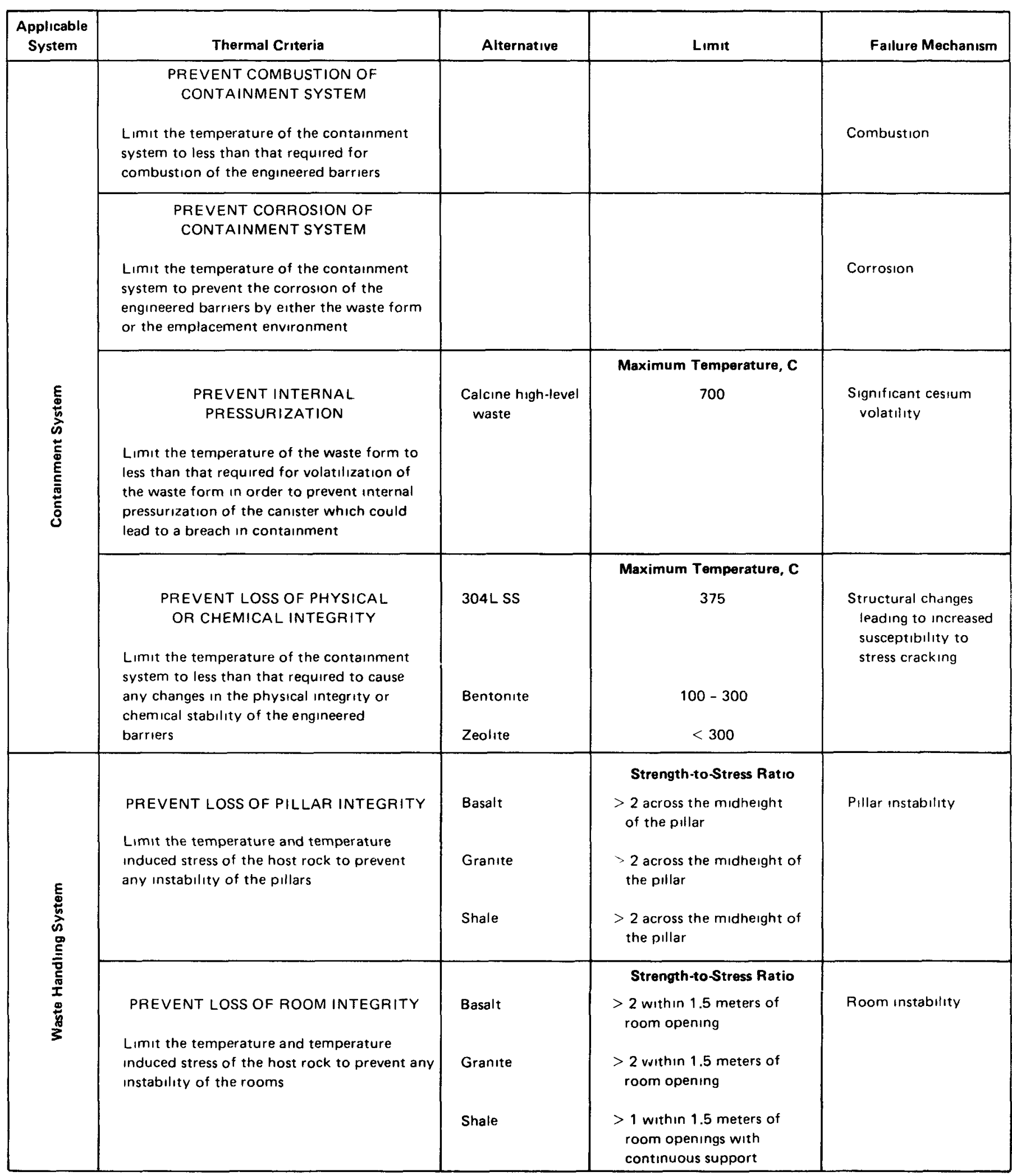


TABLE ES-1. (Continued)

\begin{tabular}{|c|c|c|c|c|}
\hline $\begin{array}{l}\text { Applicable } \\
\text { System }\end{array}$ & Thermal Criteria & Alternative & Limit & Fallure Mechanism \\
\hline \multirow{6}{*}{ 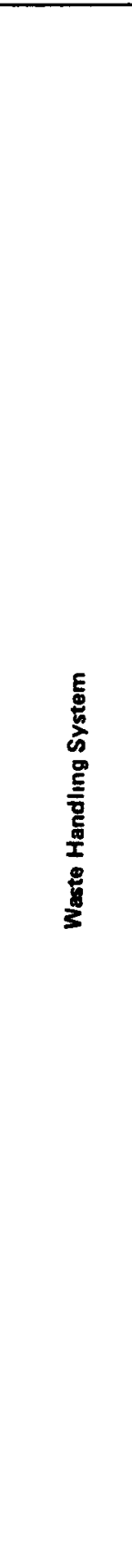 } & & $\begin{array}{l}\text { Bedded salt } \\
\text { Domed salt }\end{array}$ & $\begin{array}{c}\text { Percantage of } \\
\text { Room Closure } \\
10-15 \\
10-15\end{array}$ & Room instability \\
\hline & $\begin{array}{l}\text { PREVENT LOSS OF RETRIEVABILITY } \\
\text { Limit the temperature of the host rock in the } \\
\text { Immediate vicinity of the waste package to } \\
\text { prevent any structural changes which could } \\
\text { prohibit the retrievability of the waste }\end{array}$ & $\begin{array}{l}\text { Salt } \\
\text { Granite } \\
\text { Basalt } \\
\text { Shale }\end{array}$ & $\begin{array}{c}\text { Maximum Temperature, } \mathbf{C} \\
250 \\
350 \\
350 \\
250\end{array}$ & $\begin{array}{l}\text { Decrepitation } \\
\text { Fracture } \\
\text { Fracture } \\
\text { Fracture }\end{array}$ \\
\hline & $\begin{array}{l}\text { PREVENT LOSS OF SAFE } \\
\text { WORKING CONDITIONS } \\
\text { Limit the air temperature in the repository } \\
\text { to provide a safe, comfortable working } \\
\text { environment for personnel }\end{array}$ & $\begin{array}{l}\text { Open rooms } \\
\text { Retrieval opera } \\
\text { tions in previously } \\
\text { sealed rooms }\end{array}$ & $\begin{array}{c}\text { Maxımum Temperature, } \mathrm{C} \\
50 \\
28\end{array}$ & $\begin{array}{l}\text { Excessive air } \\
\text { temperature }\end{array}$ \\
\hline & $\begin{array}{l}\text { PREVENT EXCESSIVE WALL AND } \\
\text { FLOOR SURFACE TEMPERATURES } \\
\text { Limit the temperature of the walls, floors, } \\
\text { etc, of the repository with which men, } \\
\text { equipment, or materials may come in } \\
\text { contact }\end{array}$ & $\begin{array}{l}\text { Retrieval } \\
\text { operatıons }\end{array}$ & $\begin{array}{c}\text { Maxımum Temperature, } C \\
49\end{array}$ & Excessive temperature \\
\hline & $\begin{array}{l}\text { PREVENT LOSS OF SHAFT INTEGRITY } \\
\text { LImit the temperature of the rock mass such } \\
\text { that the shaft and its components undergo } \\
\text { no fracturing due to the induced thermo } \\
\text { mechanical stresses and experience no signifi- } \\
\text { cant ground water leakage }\end{array}$ & & & $\begin{array}{l}\text { Fracturıng and ground } \\
\text { water leakage }\end{array}$ \\
\hline & $\begin{array}{l}\text { PREVENT LOSS OF SHAFT WASTE } \\
\text { HANDLING CAPABILITY } \\
\text { Limit the temperature of the rock mass such } \\
\text { that any deformations of the shafts or shaft } \\
\text { liners will be sufficiently small to allow for } \\
\text { routine operations without major remedial work. }\end{array}$ & & & Shaft instability \\
\hline 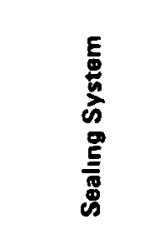 & $\begin{array}{l}\text { PREVENT LOSS OF } \\
\text { HYDROLOGIC INTEGRITY } \\
\text { Limit the temperatures of the repository so } \\
\text { that any adverse changes in the permeability } \\
\text { of the shaft and borehole seals, or backfills } \\
\text { is prohibited }\end{array}$ & & & Increased permeability \\
\hline
\end{tabular}


TABLE ES-1. (Continued)

\begin{tabular}{|c|c|c|c|c|}
\hline $\begin{array}{c}\text { Applicable } \\
\text { System }\end{array}$ & Thermal Criteria & Alternative & Limit & Failure Mechanism \\
\hline 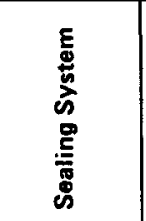 & $\begin{array}{l}\text { PREVENT LOSS OF } \\
\text { PHYSICAL INTEGRITY } \\
\text { Limit the temperatures of the repository to } \\
\text { prevent any adverse structural changes in } \\
\text { the shaft and borehole seals, or the backfills. }\end{array}$ & & & Structural changes \\
\hline \multirow{4}{*}{ 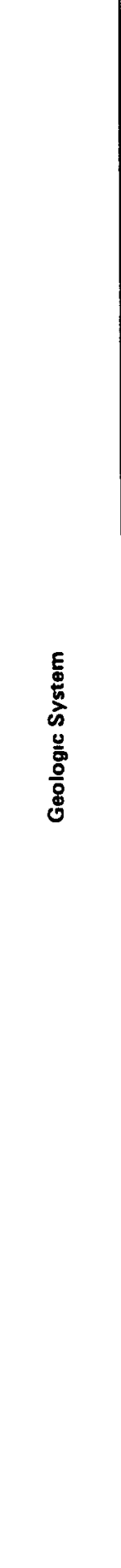 } & $\begin{array}{l}\text { PREVENT EXCESSIVE GROUND } \\
\text { SURFACE TEMPERATURE RISE } \\
\text { Limit the temperature rise at or near the } \\
\text { ground surface to prevent any adverse } \\
\text { effects on the biosphere. }\end{array}$ & $\begin{array}{l}\text { All Media } \\
\text { Bedded salt } \\
\text { Domed salt } \\
\text { Basalt } \\
\text { Granite } \\
\text { Tuff } \\
\text { Shale }\end{array}$ & $\begin{array}{l}\text { Temperature Rise, } \mathrm{C} \\
<4 \text { within } 3 \text { meters of the } \\
\text { surface }\end{array}$ & $\begin{array}{l}\text { Excessive temperature } \\
\text { Increase }\end{array}$ \\
\hline & $\begin{array}{l}\text { PREVENT THE CREATION OF } \\
\text { EXCESSIVE PERTURBED FISSURE } \\
\text { ZONE } \\
\text { Limit the thermomechanical stresses in the } \\
\text { rock mass to prevent the creation of an } \\
\text { excessive perturbed fissure zone. }\end{array}$ & $\begin{array}{l}\text { All Media } \\
\text { Bedded salt } \\
\text { Domed salt } \\
\text { Basalt } \\
\text { Granite } \\
\text { Tuff } \\
\text { Shale }\end{array}$ & $\begin{array}{l}\text { Extent of Perturbed } \\
\text { Fissure Zone } \\
<15 \text { percent of the repository } \\
\text { depth downward }\end{array}$ & Fracture \\
\hline & $\begin{array}{l}\text { PREVENT LOSS OF } \\
\text { PHYSICAL INTEGRITY } \\
\text { LImit the thermomechanical stress in the } \\
\text { rock mass to prevent the fracture of the } \\
\text { host rock or the overlying stratigraphy. }\end{array}$ & $\begin{array}{l}\text { Bedded salt } \\
\text { Dorned salt } \\
\text { Basalt } \\
\text { Granite } \\
\text { Tuff }\end{array}$ & $\begin{array}{l}\text { Strength-to-Stross Ratio } \\
1 \text { in the aquitards } \\
1 \text { in the aquitards and cap } \\
\text { rock } \\
1 \text { everywhere in the far field } \\
1 \text { in the middle } 70 \text { percent of } \\
\text { the rock column between } \\
\text { the repository and the } \\
\text { surface } \\
1 \text { in the middle } 70 \text { percent of } \\
\text { the rock column between } \\
\text { the repository and the } \\
\text { surface }\end{array}$ & Shear fallure \\
\hline & $\begin{array}{l}\text { PREVENT EXCESSIVE } \\
\text { VERTICAL DEFORMATIONS } \\
\text { Limit the thermal energy release to prevent } \\
\text { excessive uplift or subsidence of the } \\
\text { geologic system }\end{array}$ & $\begin{array}{l}\text { All Media } \\
\text { Bedded salt } \\
\text { Domed salt } \\
\text { Basalt } \\
\text { Granite } \\
\text { Tuff } \\
\text { Shale }\end{array}$ & $\begin{array}{l}\text { Vertical Displacement } \\
<3 \text { meters }\end{array}$ & $\begin{array}{l}\text { Uplift and/or } \\
\text { subsıdence }\end{array}$ \\
\hline
\end{tabular}


TABLE ES-1. (Contınued)

\begin{tabular}{|c|c|c|c|c|}
\hline $\begin{array}{l}\text { Applicable } \\
\text { System }\end{array}$ & Thermal Criterıa & Alternative & Limit & Fallure Mechan ism \\
\hline \multirow{4}{*}{ 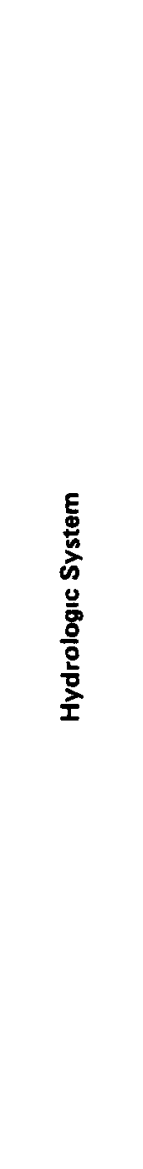 } & $\begin{array}{l}\text { PREVENT CREATION OF } \\
\text { CONVECTION CELLS } \\
\text { Limit the temperature of the rock mass to } \\
\text { prevent the creation of convection cells } \\
\text { which could increase the velocity of the } \\
\text { flow system, or decrease the effective path } \\
\text { length to the surface for radionuclide } \\
\text { migration }\end{array}$ & & & Convection cells \\
\hline & $\begin{array}{l}\text { PREVENT GROUND WATER } \\
\text { MIGRATION TOWARD HEAT SOURCES } \\
\text { Limit the temperature gradients in the rock } \\
\text { mass to prevent the migration of ground } \\
\text { water toward the heat sources }\end{array}$ & & & Brıne migratıon \\
\hline & $\begin{array}{l}\text { PREVENT HYDROTHERMAL } \\
\text { REACTIONS } \\
\text { Limit the temperature of the waste form } \\
\text { to prevent hydrothermal reactions (after } \\
\text { containment) }\end{array}$ & & & Hydrothermal reactions \\
\hline & $\begin{array}{l}\text { PREVENT EXCESSIVE TEMPERATURE } \\
\text { RISE IN NEIGHBORING AQUIFERS } \\
\text { Limit the temperature rise in the neighboring } \\
\text { aquifers to prevent any adverse effects on the } \\
\text { biosphere }\end{array}$ & $\begin{array}{l}\text { All Media } \\
\text { Bedded salt } \\
\text { Domed salt } \\
\text { Basalt } \\
\text { Granite } \\
\text { Tuff } \\
\text { Shale }\end{array}$ & $\begin{array}{l}\text { Temperature Rise, C } \\
<6 \text { in stagnant } \\
\text { aquifers }\end{array}$ & $\begin{array}{l}\text { Excessive aquifer temper } \\
\text { ature rise }\end{array}$ \\
\hline \multirow[t]{2}{*}{ 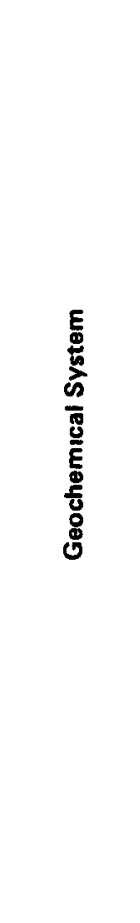 } & $\begin{array}{l}\text { PREVENT LOSS OF } \\
\text { GEOCHEMICAL INTEGRITY } \\
\text { Limit the temperature of the rock mass to } \\
\text { prevent any adverse changes in the chemical } \\
\text { composition of the rock mass which could } \\
\text { affect its capability to retard the migration } \\
\text { of radionuclidies }\end{array}$ & $\begin{array}{l}\text { Granite } \\
\text { Bedded salt } \\
\text { Domed salt } \\
\text { Basalt } \\
\text { Tuff }\end{array}$ & $\begin{array}{l}\text { Maximum } \\
\text { Temperature, } C \\
125 \text { from the near field } \\
\text { outward to a distance } \\
\text { equal to } 15 \text { persent of } \\
\text { the repository depth } \\
100 \text { outside the region } \\
\text { defined above } \\
100 \text { from the near field } \\
\text { outward to a distance } \\
\text { equal to } 15 \text { percent of } \\
\text { the repository depth } \\
75 \text { outside the region } \\
\text { defined above }\end{array}$ & $\begin{array}{l}\text { Chemical changes in } \\
\text { rock mass }\end{array}$ \\
\hline & $\begin{array}{l}\text { PREVENT ADVERSE GEOLOGY/ } \\
\text { CONTAINMENT/WASTE FORM } \\
\text { INTERACTIONS } \\
\text { Limit the temperatures of the geochemical } \\
\text { system to prevent any adverse chemical } \\
\text { reactions between the rock mass, engineered } \\
\text { barriers, or waste form }\end{array}$ & & & $\begin{array}{l}\text { Adverse geology/ } \\
\text { containment/waste form } \\
\text { interactions }\end{array}$ \\
\hline
\end{tabular}


TABLE ES-1. (Continued)

\begin{tabular}{|c|c|c|c|c|}
\hline $\begin{array}{l}\text { Applicable } \\
\text { System }\end{array}$ & Thermal Criteria & Alternative & Limit & Failure Mechanism \\
\hline 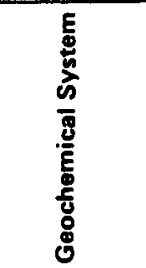 & $\begin{array}{l}\text { PREVENT LOSS OF } \\
\text { SORPTION PROPERTIES } \\
\text { Limit the temperatures of the rock mass and } \\
\text { engineered barriers to prevent the loss of any } \\
\text { sorption properties they may have. }\end{array}$ & Zeolites & $\begin{array}{c}\text { Maximum Temperature, } \mathbf{C} \\
<300\end{array}$ & Loss of sorption properties \\
\hline
\end{tabular}


which the system alternative can fail. As an example, the waste form system can fail through changes in 1ts original composition, which for spent fuel can occur above approximately $250 \mathrm{C}$ due to the oxidation of the ceramic fuel from $\mathrm{UO}_{2}$ to $\mathrm{U}_{3} \mathrm{O}_{8}$.

As can be seen from Table ES-1, not all of the thermal criteria developed from the literature survey could be assigned thermal limits. These missing thermal limits include such items as the effect of increased temperatures on canister corrosion, the volatility of the wastes, the migration of ground water towards heat sources, and mediacanister-waste form interactions. These gaps in the table occur because thermal limits for the corresponding thermal criteria were not found in the literature reviewed. Also, in some instances, more than one documented thermal limit was found for a thermal criterion.

\section{Applications}

The primary purpose of the thermal criteria hierarchy is the identification of those aspects of the waste disposal system which are adversely affected by the thermal energy released by the nuclear waste and the interrelationships among these areas. This approach will help to evaluate the thermal acceptability of a given repository design in a systematic fashion.

To illustrate how the thermal criteria hierarchy could thus be used, the thermal acceptability of a simple repository design was evaluated. Table ES-2 describes the repository configuration chosen for this purpose, a spent fuel BWR repository in salt. A set of maximum permissible temperatures for this repository design was then obtained 
Table ES-2. Repository Characteristics

Characteristics

Specifications

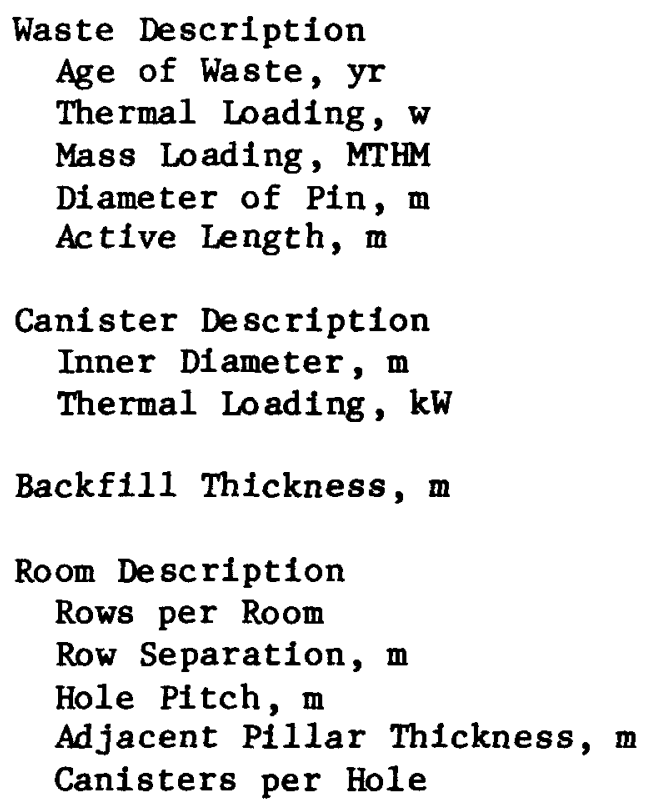

Repository Depth, m

Materials

Waste

Canister

Backfill

Medium
10

2.86

0.0029

0.0062

4.0

0.23

2.6

0.15

2

10.67

25.65

22.97

1

600

BWR Spent Fuel PIns

Carbon Stee1

Crushed Salt

Bedded Salt 
from the thermal criteria hierarchy. These are listed in Table ES-3. Where temperature limits were not available, such as the corrosion $11 \mathrm{mit}$ for the canister, they were not included.

The results of the thermal analysis of this repository design are shown in Figure ES-3. As can be seen from the radial temperature distribution of the spent fuel canister, the containment waste form, canister, and salt emplacement temperatures are all below their maximum values. At a distance of 0.86 meters from the centerline, the temperature of the salt is well below $75 \mathrm{C}$ and declining, thereby assuring that the near-field and far-field limits will be met. At 100 years after disposal, the spent fue 1 centerline temperature is below $100 \mathrm{C}$ and declining, as can be seen by examining the variation of the spent fuel centerline temperature with time. Assuming a required containment period in excess of 100 years, the postcontainment spent fuel temperature limit will thus be met.

Based strictly on temperature considerations, the chosen repository design is acceptable. A thorough analysis, however, would have required the evaluation of a complete set of thermal limits. Any missing thermal limits, therefore, would need to be determined, and the analysis would need to include not only temperature calculations, but also thermomechanical and hydrological calculations.

\section{$\underline{\text { Recommendations }}$}

The thermal criteria hierarchy developed here should be periodically reviewed to incorporate other failure mechanisms and the 
Table ES-3. A Partial Set of Restrictive Temperatures for the Repository Configuration Shown in Table ES-2(a)

Waste Form/Canister/Medium

Maximum Temperature, C

Spent Fue1

during containment period

300

after containment period

100

Carbon Steel Canister

375

Salt

emplacement area

250

near field

100

far field

75

(a) Where temperature limits were not available for the failure mechanisms developed in Chapter 3, they were not included. 


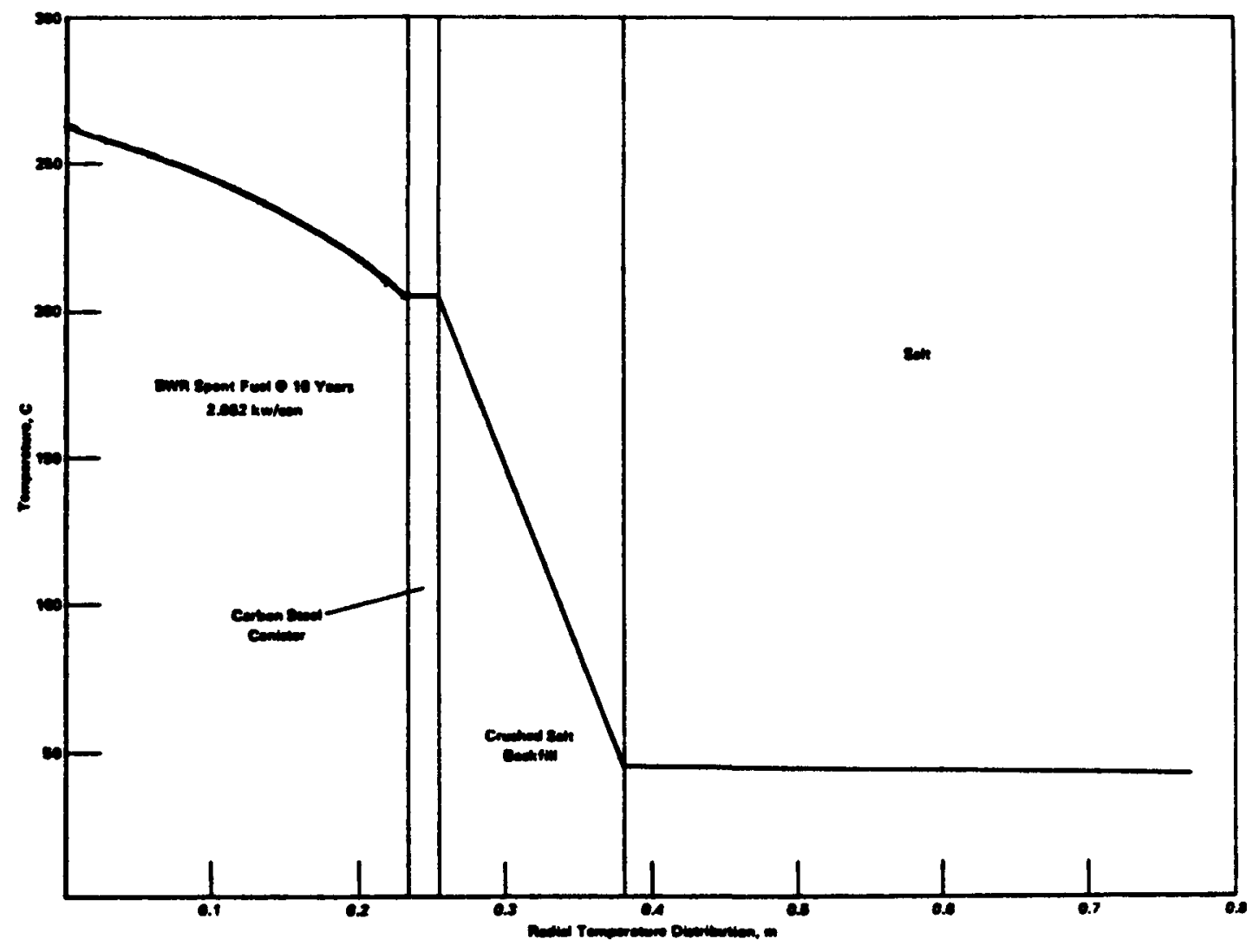

RADIAL TEMPERATURE DISTRIBUTION OF SPENT FUEL WASTE PACKAGE

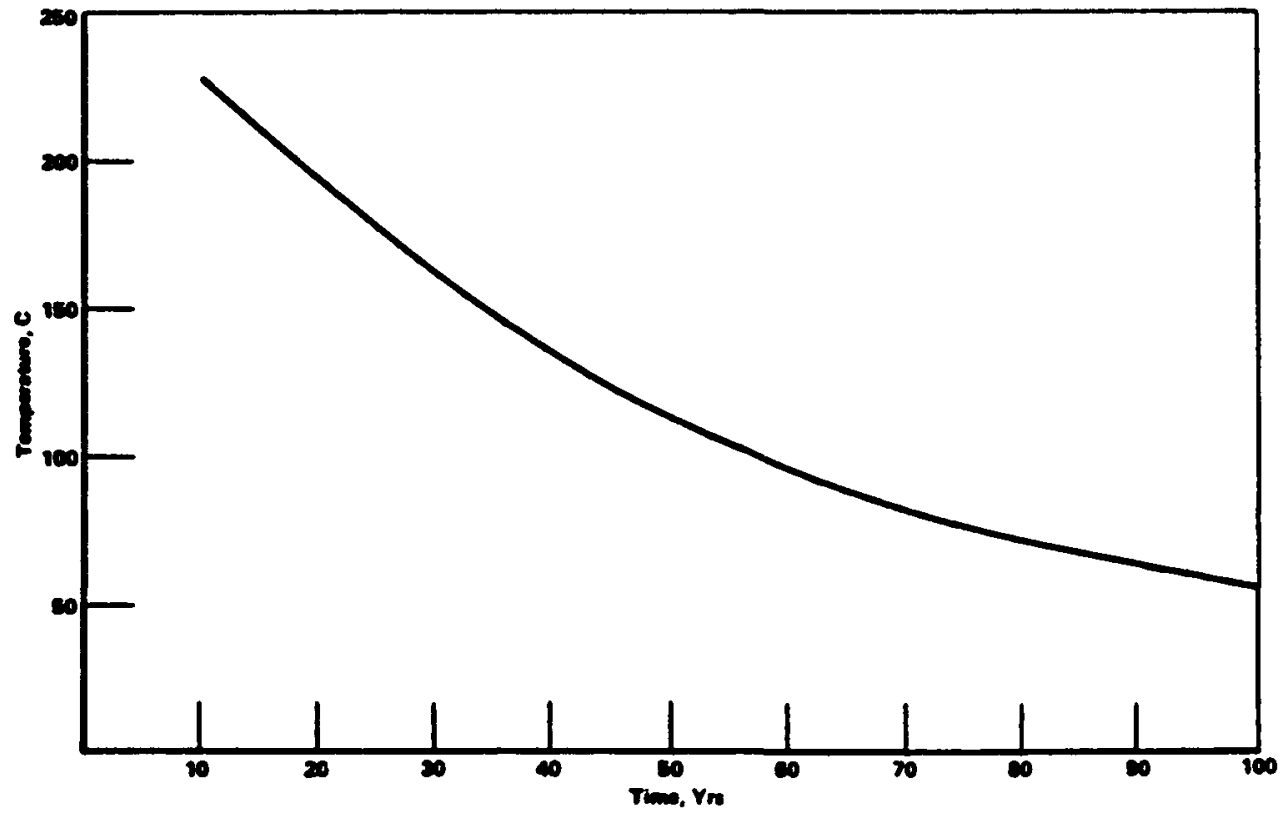

VARIATION OF SPENT FUEL CENTERLINE TEMPERATURE WITH TIME

FIGURE ES-3. RESULTS OF THE THERMAL ANALYSIS OF THE EXAMPLE REPOSITORY CONFIGURATION 
missing thermal limits. Care should be taken in updating the hierarchy and determining the missing thermal $11 \mathrm{mits}$ in order to maintain internal consistency. 
1 INTRODUCTION

The purpose of this paper is first to provide a summary of all the available thermal criteria for nuclear waste isolation in geologic repositories and their bases in current use, and second to identify those areas where either the criteria do not exist or the existing criteria are inadequate. To accomplish this, a hierarchy of thermal criteria will be developed. Analyses will then be conducted to demonstrate the interrelationships of thermal criteria in the hierarchy. In this first chapter a discussion of why thermal criteria need to be developed will be presented. Following this, a brief description of the mined geologic system, and the waste types and their sources is given. The last section of this chapter will outline the organization of the rest of this report.

\subsection{THE NEED FOR THERMAL CRITERIA}

One of the major factors to be considered in the isolation of nuclear waste is the heat generated by the waste. Many of the technical uncertainties associated with the disposal of nuclear wastes in mined geologic repositories are related to this thermal energy release, the resulting thermal environment, and the impact this thermal environment has on the waste disposal system. The heat generated by the nuclear wastes w111 eventually flow from the waste form, through the canister and emplacement area, into the host formation, through the 
surrounding and overlying rock to the surface and then out into the atmosphere. This migration of thermal energy will have impacts on:

- The integrity and the potential retrievability of the waste packages

- Mine room and pillar stability

- The integrity of the host rock and surrounding rock

- Any overlying aquifers or ground water flow

- The long-term uplift and subsidence of the overlying rock, and

- The biosphere.

Physical and chemical changes in the waste form or canister resulting from increased temperatures could jeopardize the integrity of the waste package if they were not controlled. As the surface temperature of the canister increases so does its susceptibility to corrosion. Should corrosion progress to the point where the canister is breached, the waste form will then be exposed to an environment which might contain ground water. Ground water provides the primary mechanism by which radionuclides can be transported to the environment. Any physical or chemical changes that may have occurred in the waste form are therefore important, as such changes will usually tend to decrease the waste form's leach resistance and generally increase the mobility of the waste. Leach rates for waste glasses, as an example, have been found to increase by approximately a factor of 10 for an increase of $100 \mathrm{C}$ in temperature (U.S. Department of Energy, 1979). Stressrupture of spent fuel pin cladding may occur at temperatures greater than $380 \mathrm{C}$, thereby decreasing the spent fuel's leach resistance.

As the heat generated by the wastes is transferred to the host formation the question of mine stability and integrity of the host rock 
and surrounding medium becomes important. An added concern for repositories in salt is the decrepitation of the salt. The introduction of heat into this system will induce stresses in the host rock and the surrounding formation. These thermally induced stresses must be considered in the design of a repository to insure its structural stability. If the structural integrity of the host rock is lost, the possibility of ground water intrusion is increased. If the loss of structural integrity occurs in the near term, the ability to emplace and retrieve the nuclear wastes may also be endangered. In the stratigraphy overlying the repository, the heat generated by the emplaced wastes will cause the rock mass to expand, thus inducing positive vertical surface displacement. Then, as the heat-generation rate decreases, negative vertical surface displacements will occur. This deformation of the overlying strata may cause fracturing in the rock, thereby causing perturbations in the natural hydrological flow. Again, this could provide a path for the transport of radionuclides to the environment .

To assure that the energy generated by the emplaced wastes will not have a detrimental effect on a repository, a systematic determination of repository thermal design is required. This includes the establishment of limits for conditions affected by heat and, from these, the determination of acceptable thermal loads that will not violate safety, engineering, and operational requirements. These design limits can be specified in terms of temperature; thermomechanical, thermohydrological, and thermochemical criteria; and performance constraints or limits. 
Currently, it is not clear which part of the waste disposal system will have the most restrictive temperature limit. This limiting temperature could be the maximum waste form temperature, the waste form surface temperature, the container surface temperature, the temperature of the undisturbed rock immediately surrounding the container, or the temperature at some point in the surrounding geology (the near or far field). Also, the location of this limiting temperature will probably be different for each potential site.

\subsection{THE MINED GEOLOGIC DISPOSAL SYSTEM}

The concept of a mined geologic repository for the disposal of nuclear wastes is briefly summarized in this section. Figure 1-1 shows an artist's conception of a geologic repository and its support facilities. Surface facilities at the site provide for unloading the waste from trucks and/or rafl cars, preparation of the waste for emplacement, and transfer of the waste to the underground workings. Excavated rock storage, general maintenance, administrative, and support areas are also located at the surface. The surface facilities will be connected by several shafts to the underground system.

The repository will provide for the receipt, preparation, transfer underground, and the emplacement and containment after closure of the radioactive wastes. In addition, the repository will provide the capability to monitor and, if necessary, retrieve the wastes.

A key element in the mined geologic disposal concept is the waste package. Figure 1-2 shows a possible schematic waste package and emplacement configuration for a spent fuel assembly. The function of the waste package is to provide for handling and emplacement and to 


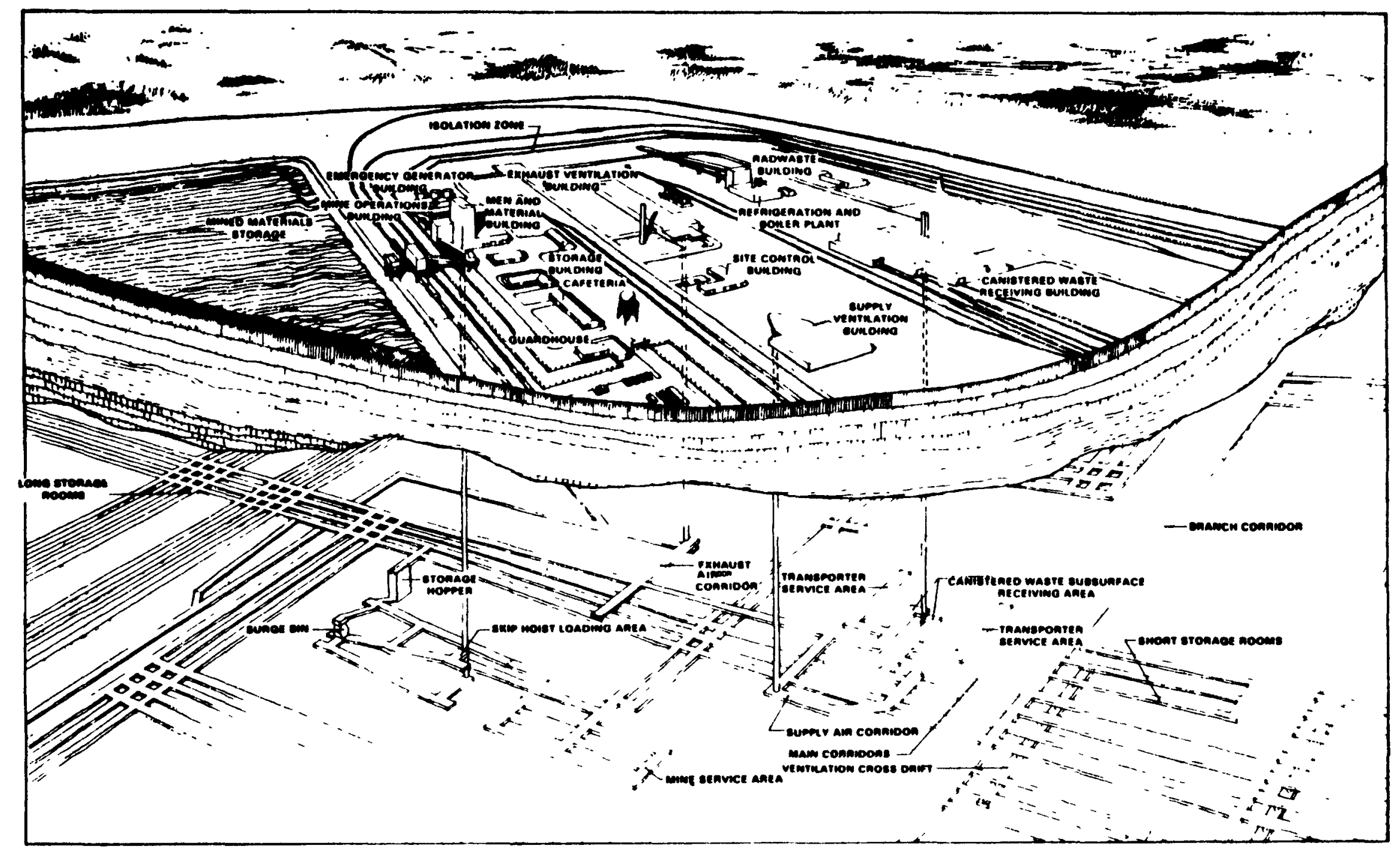

FIGURE 1-1. ARTIST'S CONCEPT OF A GEOLOGIC REPOSITORY AND ITS SUPPORT FACILITIES (U.S. DEPARTMENT OF ENERGY, 1980) 


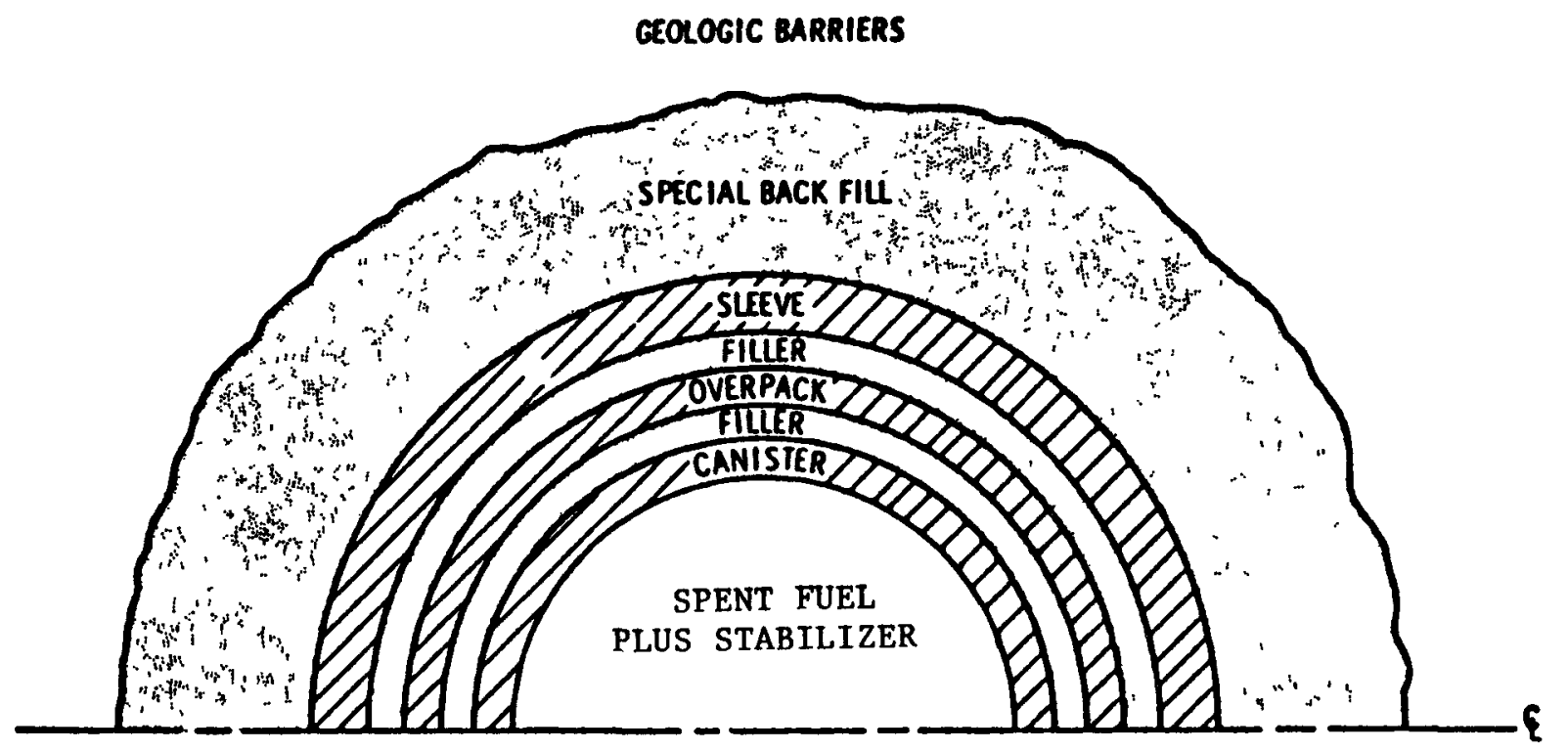

FIGURE 1-2. SCHEMATIC DESIGN OF A WASTE PACKAGE FOR SPENT FUEL (U.S. DEPARTMENT OF ENERGY, 1980) 
insure retrievability of the wastes. During the thermal period the package must also provide for containment.

The primary purpose of the waste disposal system is to contain and isolate the radioactive waste. This goal is achieved by containing the waste for a specified period of time and controlling the release of the radionuclides after the containment period. The concept is to provide a series of independent barriers to the release of radionuclides to the biosphere. The multiple barriers that form this system fall into two categories :

- Geologic or natural barriers, and

- Engineered barriers.

Geologic barriers provide effective, long-term, naturally occurring barriers which isolate nuclear waste from man and the biosphere. Engineered barriers contain the waste by delaying the time of release and retarding the rate of release of radionuclides to the geologic environment. These man-made barriers must also be designed to withstand the more severe thermal conditions encountered initially. The nature of the host rock is basic to the determination of the other barriers in the multibarrier system, and several media types are being considered. Properly chosen rock structures provide physical and chemical properties that contribute to repository strength. Sufficient repository depth and lateral extent of the rock mass contribute to the isolation capability of the repository. Geologic formations currently being investigated include bedded salt deposits and salt domes, basalt, and crystalline rocks such as granite, shale, and tuff. Figure 1-3 shows the locations of these geologic formations in the continental United States. Some regions of interest are shown in Figure 1-4. 


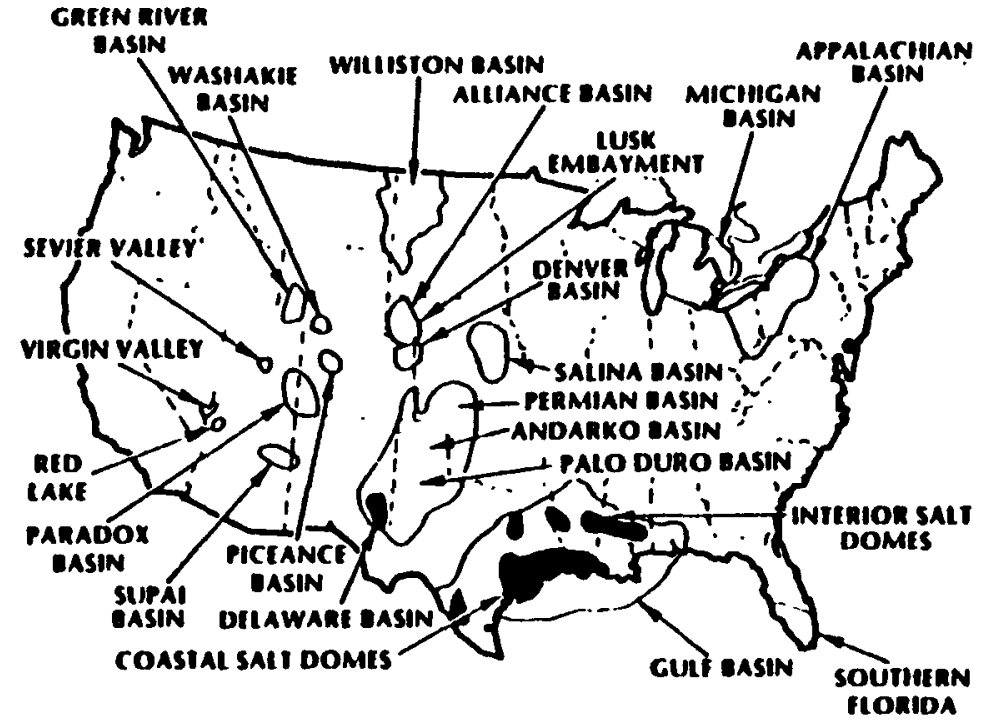

ROCK SALT DEPOSITS

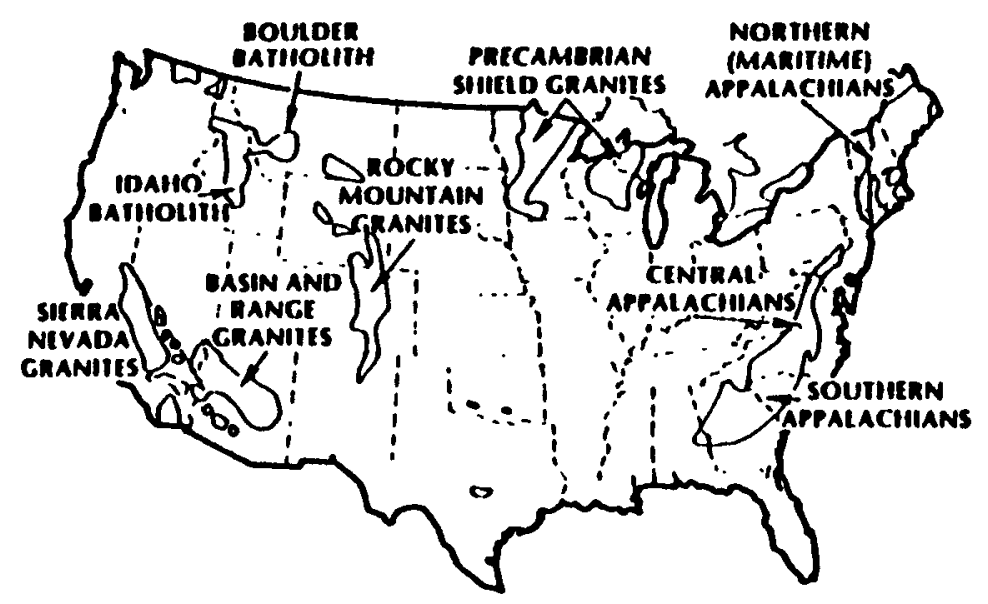

GRANITIC TORMATIONS

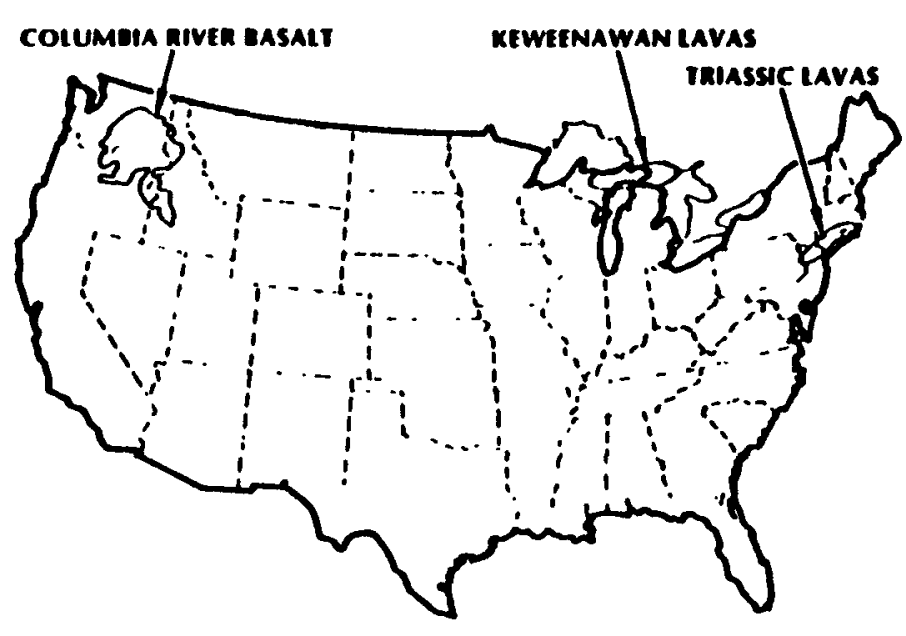

BASALTS

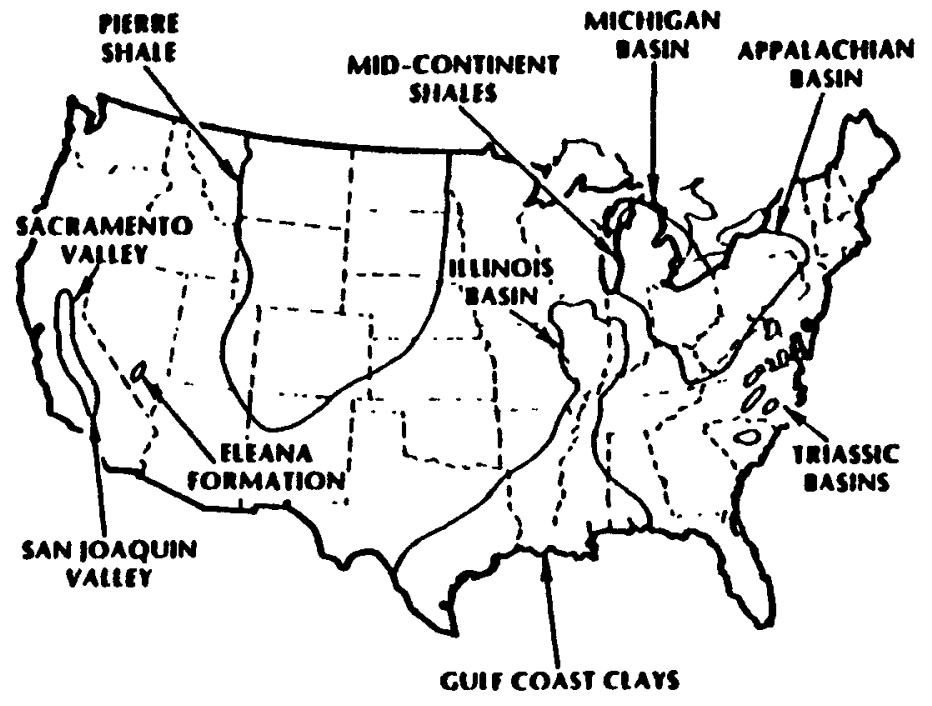

ARGILLACEOUS FORMATIONS

FIGURE 1-3. GEOLOGIC FORMATIONS BEING INVESTIGATED AS POSSIBLE HOST MEDIA 


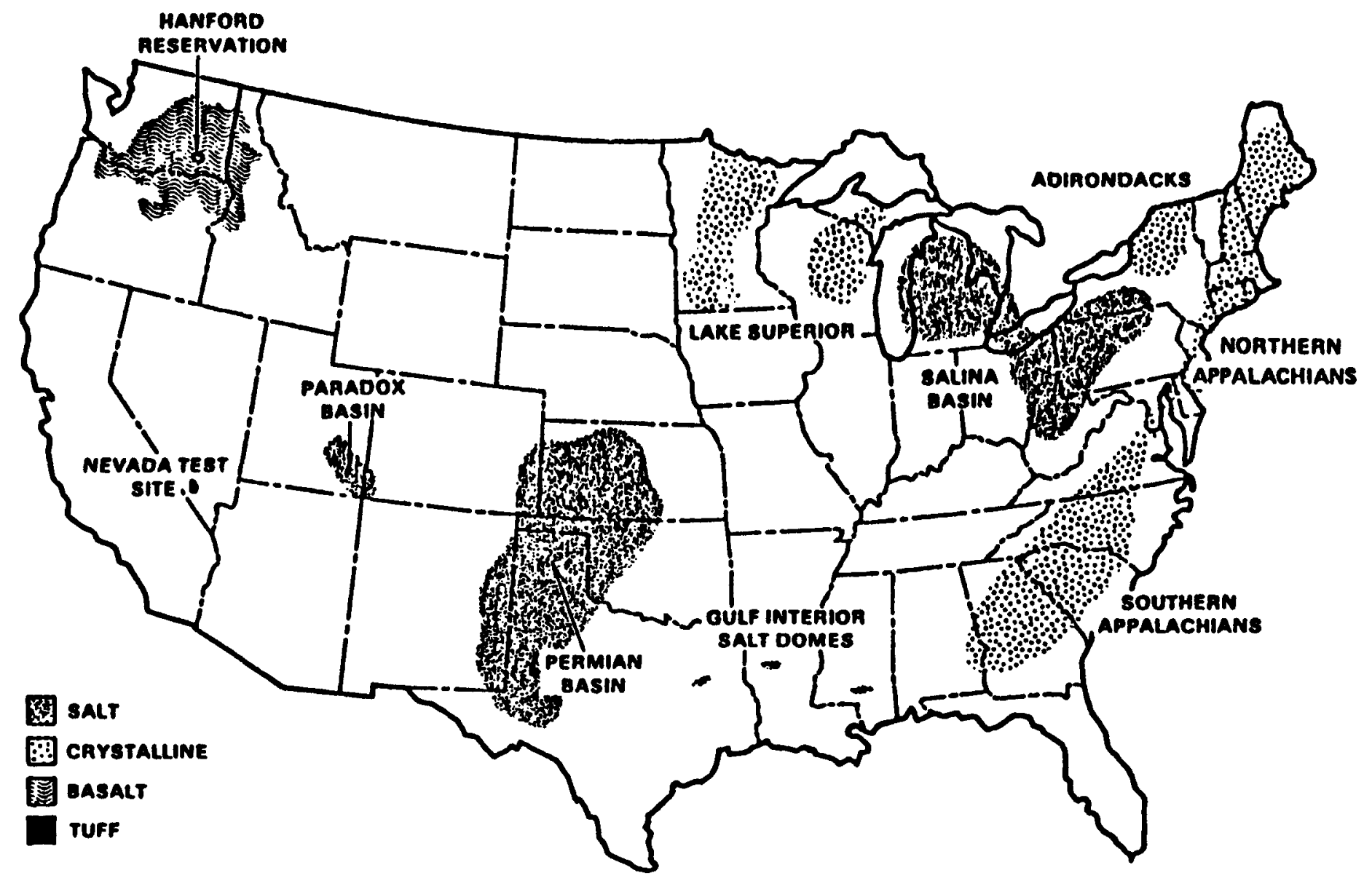

FIGURE 1-4. REGIONS OF INTEREST FOR TERMINAL STORAGE OF NUCLEAR WASTE 


\subsection{WASTE TYPES AND SOURCES}

Sources of nuclear waste originate not only from electrical power generation but also from military, medical, industrial, and agricultural activities. Nuclear waste can be divided into six major categories depending on their origin, level of radioactivity, and potential hazard. These are spent (unreprocessed) fuel, commercial and defense high-level waste, transuranic wastes, cladding and hardware wastes, low-level wastes, and tailings.

Spent fuel is that fuel discharged from light water reactors (LWRs). Fuel for LWRs is enriched uranium dioxide $\left(\mathrm{UO}_{2}\right)$. The uranium dioxide is then sintered into the form of right circular cylinders approximately 1.5 centimeters in length and between 0.75 and 1.25 centimeters in diameter, depending on the reactor design. These pellets are then placed into long narrow tubes of 366 to 376 centimeters in length to form the fuel rods. A typical fuel rod is shown in Figure 1-5. The fuel rods are then arranged in a square array held together by spacer grids, end nozzles, and other structural materials to form a fuel assembly. The physical dimensions vary according to LWR type (pressurized water reactors, PWRs, or the boiling water reactors, BWRs), the four reactor suppliers and the many different reactor designs. Figure 1-6 shows a typical PWR fuel assembly.

High-level wastes originate when spent fuel, either from commercial or defense reactors, is reprocessed to recover uranium and plutonium. These wastes are characterized by high energy radiation. High-level waste consists of 99 percent fission products and actinides, approximately 0.1 percent lodine and bromine, and 0.5 percent uranium 


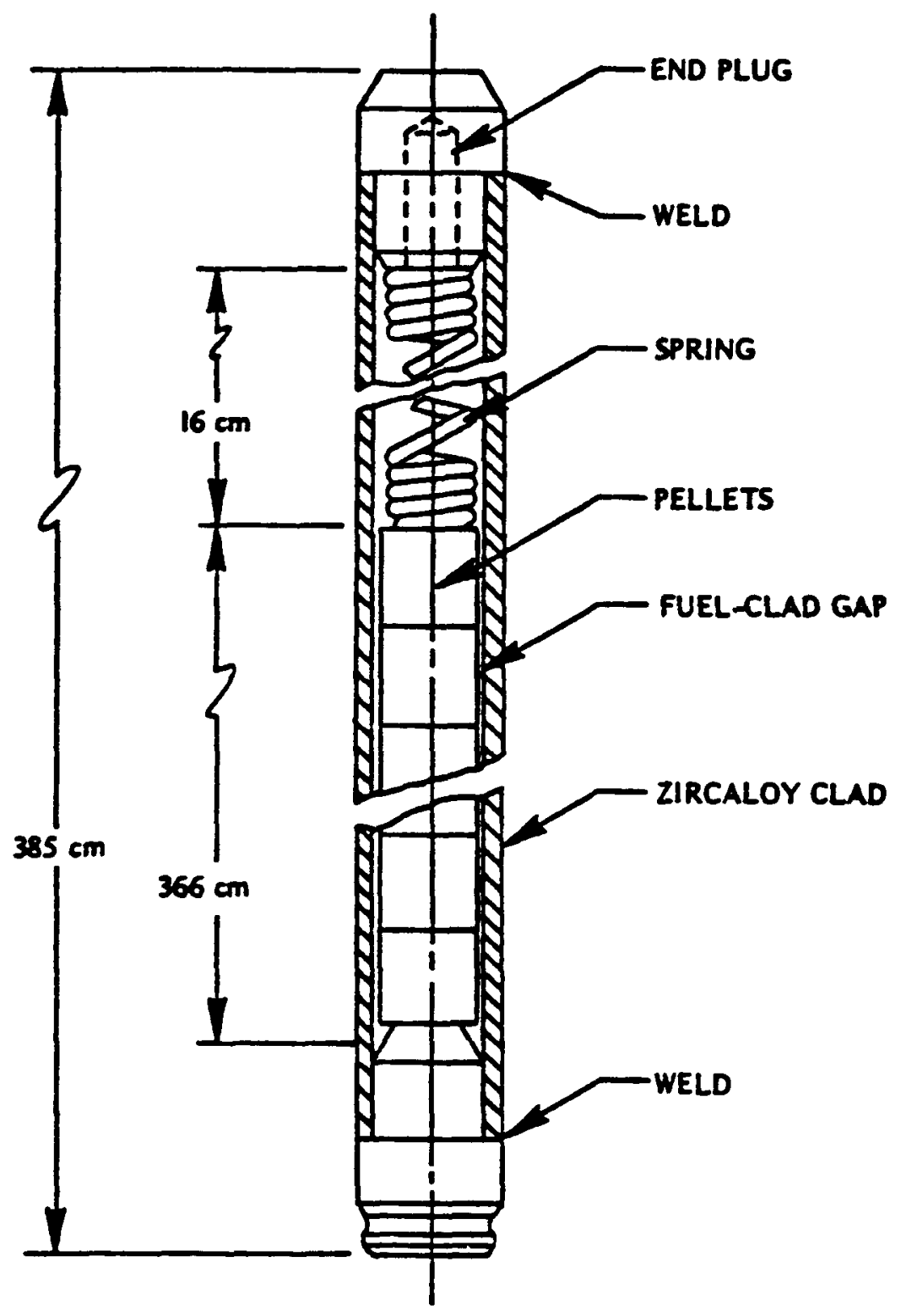

FIGURE 1-5. TYPICAL PWR FUEL ROD (O'HARA ET AL, 1979) 


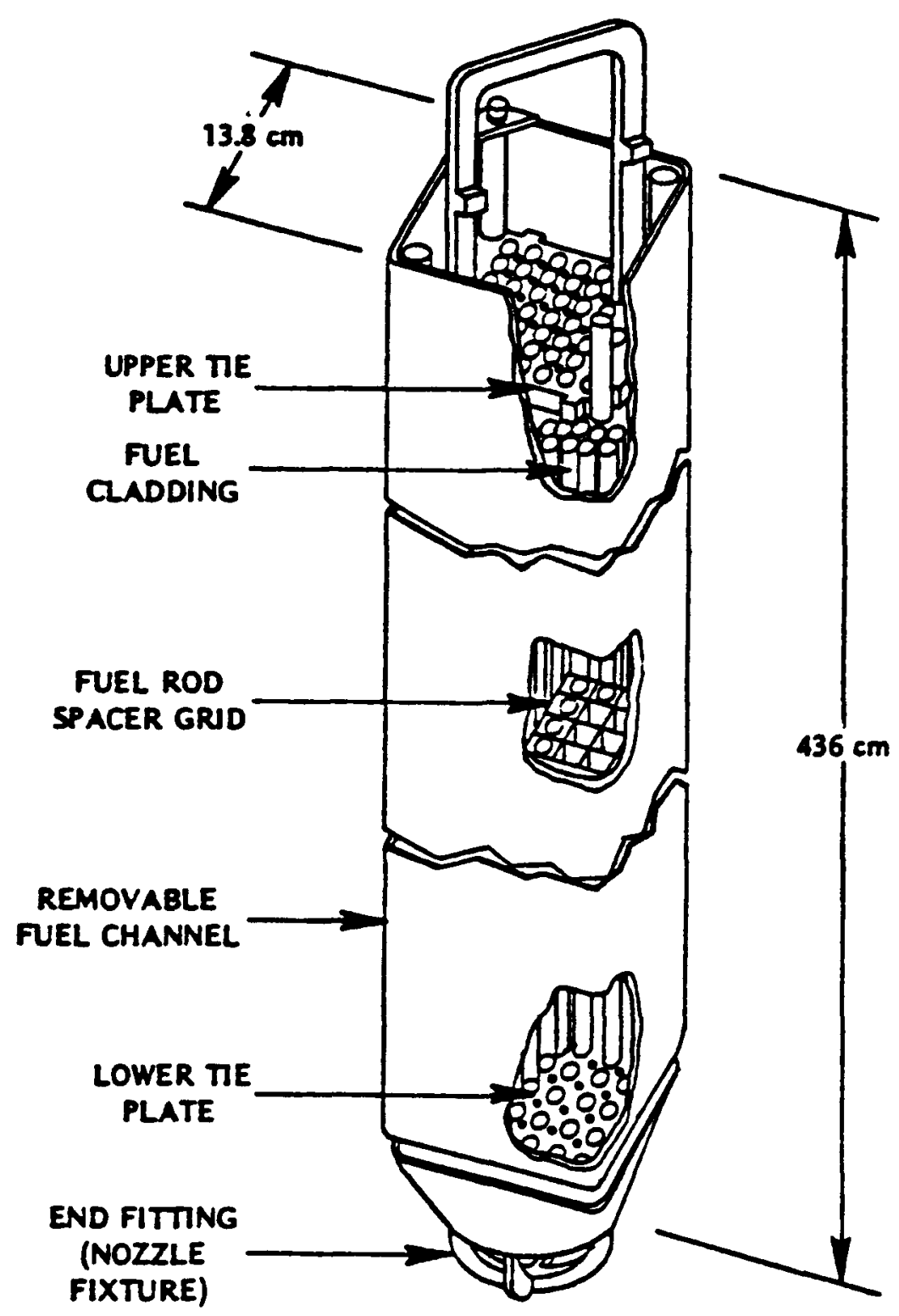

FIGURE 1-6. PWR FUEL ASSEMBLY (O'HARA ET AL, 1979) 
and plutonium. In the uranium-only recycle option, however, the plutoniun content could be significantly higher. Present regulations require that all-1iquid high-level waste be converted to a dry solid within five years after reprocessing.

As with high-level wastes, most transuranic wastes result from reprocessing. They consist of materials contaminated with elements heavier than uranium. Transuranic waste is characterized by medium to low energy radiation. Transuranic elements are often very long-1ived. Cladding and hardware wastes also originate with reprocessing. They consist of leached hulls, support rods, control rod drives, end fittings, support grids, and assorted springs and spacers. The major concern in cladding and hardware waste disposal is the capability of the materials to spontaneously ignite in air or other environs.

Low-level wastes are those radioactive wastes not classified as high-level radioactive waste, transuranic waste, spent nuclear fuel, or by-product material. These wastes typically consist of small amounts of radioactive material in large volumes. Similarly, tallings are the by-products of the uranium mining and milling and consist of large volumes of rock and soil that have residual natural radioactivity. Neither of these waste types requires disposal in mined geologic repositories.

The temperatures which result with the disposal of these various waste types will not be the same in all cases. They will vary due to the differences in thermal output and activity decay among the waste types. With spent fuel the heat generation rates of discharged PWR and BWR fuel assemblies vary with burnup, specific power, and the composition of the assemblies when put into the reactor. The specific power 
level affects the short-term heat generation rate, while the burnup affects the long-term heat generation of the assemblies. Heat generation rates for high-level wastes will vary with the reactor type (PWR or $\mathrm{BWR})$, fuel type $\left(\mathrm{UO}_{2}\right.$ or mixed oxide fuel), and the reprocessing cycle.

\subsection{REPORT ORGANIZATION}

Following the introduction, Chapter 2 will identify the existing thermal criteria and their sources. Chapter 2 groups the thermal criteria as they apply to the very-near-field, near-field, and farfield regions of the repository. The development of the thermal criteria hierarchy is presented in Chapter 3. After a general discussion of the thermal criteria hierarchy, detailed discussions of each of the geologic disposal subsystems and their thermal criteria are given. Chapter 4 outlines some possible uses of the thermal criteria hierarchy and presents an example. The interrelationships among the criteria are also discussed. Chapter 5 provides recommendations for further work. 


\section{LITERATURE REVIEW}

For purposes of analysis, the repository has been divided into three overlapping regions, the very near field, the near field, and the far field. The very near field consists of the waste form and its associated canister and emplacement area. The near field consists of the actual excavation area--the rooms and pillars. The far field consists of the formation and overlying stratigraphy at distances far removed from the repository. Without exception the existing thermal criteria have been defined with respect to these regions. For the purposes of this report the same repository divisions will also be used. The thermal constraints which apply to the very near field, near field, and far field are discussed in Sections 2.1, 2.2, and 2.3, respectively.

\subsection{VERY NEAR FIELD}

In the very near field the major concern is the maximum temperature of the waste form, canister, sleeve, overpack, and backfill. The influencing factors include:

- The canister and canister well design

- The very-near-field thermal properties

- The short-term thermal decay rates of the waste

- The individual canister thermal load, and

- The average canister spacing.

Peak temperatures are usually reached in the first five to ten years. 
Table 2-1 lists the recommended peak temperatures for the waste forms that are under consideration. The predominant source of information for waste form temperatures is G. H. Jenks (1977). For the case of high-level waste, Jenks did not make the distinction between defense and commercial sources. The supporting arguments for the temperature limits are presented in the succeeding paragraphs.

For typical borosilicate waste glasses Jenks (1977) chose a temperature limit of $500 \mathrm{C}$ based upon the following. The transition temperature for typical borosilicate waste glasses is approximately $500 \mathrm{C}$, with a slightly higher softening temperature. Significant increases in cracking and leach rates have been observed in test glasses that were heated for periods of a few months in the temperature range 500 to $800 \mathrm{C}$ (Jenks, 1977). And, the migration of heavy, separable phases in the glass might take place above the softening temperature. Later work by Turcotte and Wald (1978) concerning the effects of temperature on the rate of devitrification of the waste glass during retrievable geologic storage has prompted Jenks to suggest the $500 \mathrm{C} 1$ imit be reduced to $375 \mathrm{C}$ during retrievable geologic storage. Turcotte and Wald (1978) have shown that considerable devitrification will occur at times less than one year at a temperature of $500 \mathrm{C}$.

Devitrification is the transition of the molecular structure of glass from the unordered or amorphous state to an ordered or crystalIine state (O'Hara et al, 1979). There is a concern that when waste glasses devitrify the impurities in the glass may end up in the intergranular boundary areas where they may be easily leached. Devitrification has been observed to increase the leach rate of glass by a factor of two or three (Mendel, 1978). 
Table 2-1. Recommended Maximum Temperatures for the Waste Form

\begin{tabular}{|c|c|c|}
\hline Waste Form & & Laximum Temperature, $\mathrm{C}$ \\
\hline $\begin{array}{l}\text { Borosilicate Glass High- } \\
\text { Level Waste }\end{array}$ & $\begin{array}{l}500 \\
375\end{array}$ & $\begin{array}{l}\text { (Jenks, 1977) } \\
\text { (Turcotte and Wald, 1978) }\end{array}$ \\
\hline Calcine High-Level Waste & 700 & (Jenks, 1977) \\
\hline $\begin{array}{l}\text { Sintered Glass Ceramic } \\
\text { High-Leve1 Waste }\end{array}$ & 800 & (Jenks, 1977) \\
\hline Spent Fuel & $\begin{array}{l}200 \\
370\end{array}$ & $\begin{array}{l}\text { (Jenks, 1977) } \\
\text { (Blackburn, 1978) }\end{array}$ \\
\hline $\mathrm{UO}_{2}$ & 250 & (Cordf unke, 1969) \\
\hline Glass Transuranic Waste & 500 & (Jenks, 1977) \\
\hline Cement Transuranic Waste & $\begin{array}{l}110 \\
150\end{array}$ & $\begin{array}{l}\text { (Jenks, 1977) } \\
\text { (Lokken, } 1978 \text { and the } \\
\text { American Society for Test- } \\
\text { ing and Materials, 1978) }\end{array}$ \\
\hline Bitumen Transuranic Waste & 80 & (Burns, 1971)(a) \\
\hline $\begin{array}{l}\text { Thermosetting Resin } \\
\text { Transuranic Waste }\end{array}$ & 300 & (Gilmore, 1977) \\
\hline $\begin{array}{l}\text { Urea-Formaldehyde Resin } \\
\text { Transuranic Waste }\end{array}$ & 300 & (Columbo and Neilson) \\
\hline $\begin{array}{l}\text { Slagging Pyrolysis Incinerator } \\
\text { Transuranic Waste }\end{array}$ & (b) & $\begin{array}{l}\text { (U.S. Department of } \\
\text { Energy, 1979) }\end{array}$ \\
\hline $\begin{array}{l}\text { Fused Cladding and Hardware } \\
\text { Waste }\end{array}$ & 400 & (Jenks, 1977) \\
\hline $\begin{array}{l}\text { Compressed Cladding and } \\
\text { Hardware Waste }\end{array}$ & 200 & (Jenks, 1977) \\
\hline $\mathrm{PuO}_{2}$ & 500 & (Jenks, 1977) \\
\hline Gaseous Fission Product Waste & (c) & (Miller and Wurm, 1980) \\
\hline
\end{tabular}


Table 2-1. (Continued)

(a) The maximum allowable temperature for bitumen is very dependent on the waste type and quantity of waste incorporated in it. For bitumen containing salts from reactor water cleanup, a temperature 1 imit of $80 \mathrm{C}$ is recommended to avold the separation of any incorporated salts.

(b) A temperature limit for the waste form from the slagging pyrolysis incinerator has not yet been reported. The temperature limit could be quite high, however, since the processing temperature of the incinerator is $1650 \mathrm{C}$.

(c) Solid waste forms for gaseous fission products are silver zeolite, calcium carbonate, metal matrices, and polymer matrices. Temperature limits for these waste forms have not yet been established.

Jenks (1977) specifies a temperature limit of $700 \mathrm{C}$ for calcine waste since significant cesium volatility occurs at temperatures greater than $750 \mathrm{C}$. Calcine is a granular substance consisting of the simple oxides of waste nuclides formed by heating high-level liquid waste in air to high temperatures.

Preliminary evidence has shown sintered glass ceramic high-level waste to be stable to at least $800 \mathrm{C}$ (Jenks, 1977). Glass ceramics are formed by a controlled devitrification, thereby eliminating the potentially detrimental effects caused by uncontrolled devitrification. The final product consists of small crystals held together with a glassy phase.

Several temperature limits have been suggested for spent fuel, all with the same intent -- maintaining the integrity of the fuel. Jenks (1977) has reported that at a temperature of about $200 \mathrm{C}$ the protective oxide film of the Zircaloy cladding will degrade in the absence of an oxidant. Blackburn et al (1978) have suggested that 
stress-rupture of spent fuel pins will occur at a temperature of $380 \mathrm{C}$ in PWR fuel assemblies and at a slightly higher temperature in BWR fuel assemblies. As a result of this, Blackburn et al (1978) recommended a maximum spent fuel temperature of $370 \mathrm{C}$. The Management of Commercially Generated Radioactive Wastes (U.S. Department of Energy, 1980), using Blackburn's work as a data source, chose a maximum spent fuel temperature of $300 \mathrm{C}$ because of some residual uncertainty concerning possible stress-corrosion cracking.

In the presence of oxygen and high temperatures, $\mathrm{UO}_{2}$ can be oxidized to $\mathrm{U}_{3} 0_{7}$ or $\mathrm{U}_{3} 0_{8}$. Up to $250 \mathrm{C}$, U0 2 can be oxidized to $\mathrm{U}_{3} \mathrm{O}_{7}$ with little change in volume. Above $250 \mathrm{C}$ oxidiation to $\mathrm{U}_{3} \mathrm{O}_{8}$ results in a large volume expansion which crumbles the uranium oxide to powder and could split the Zircaloy cladding (Cordfunke, 1969).

Jenks (1977) chose the same maximum temperature, $500 \mathrm{C}$, for transuranic waste glass as he did for borosilicate high-level waste glass. Jenks, however, also noted that transuranic waste would probably have a relatively low thermal power and as a result the actual maximum temperature would be less than $500 \mathrm{C}$.

For cement transuranic waste the immobilization of the waste occurs by mixing aqueous solutions, slurries, and dry particulates with cement. The optimum proportions of cement and waste will vary and the water content must be carefully controlled to assure concretization without creating excess free water. Jenks (1977) has suggested a maximum temperature of $110 \mathrm{C}$ for cement, which is the Atlantic Richfield et al (1977) maximum temperature for normal conditions in structural concrete in 1ong-term, 1,000 years, surface storage of 
high-level waste. Lokken (1978) and the American Society for Testing and Materials (1978) have recommended a temperature limit of $150 \mathrm{C}$ for cement to avoid dehydration and thermal stresses which lead to microcracking and a reduction in structural properties.

Bitumen transuranic waste is created by mixing wet and solid wastes with bitumen at elevated temperatures to evaporate the water. The bitumen waste mixture is then usually discharged into drums. Depending on the type of bitumen, the softening point varies from 34 to 65 C (International Atomic Energy Agency, 1970). At the softening point several effects may occur: phase separation will occur near the softening temperature; mixing of tetraborates, iron, and aluminum salts causes hardening of the bitumen; and heating above the softening point can cause emission of gas or aerosols. The maximum temperature for bitumen is also very dependent on the waste type and loading. For example, $80 \mathrm{C}$ is the recommended maximum temperature for bitumen containing salts from reactor water cleanup to avoid the separation of any incorporated salts (Burns, 1971).

The principle of the thermosetting resin process is to disperse the radioactive material in a polyester resin dissolved in styrene, obtain a homogeneous mixture, and then induce polymerization. A maximum temperature of $300 \mathrm{C}$ has been recommended for thermosetting resins to avoid any decomposition of the material (Gilmore, 1977).

Liquid and dry transuranic waste is mixed with urea-formaldehyde resin and the reaction is catalyzed by homogeneous additions of $\mathrm{NaHSO}_{4} \cdot$ Urea-formaldehyde polymerizes and traps the waste in a solid structure with little heat or volume expanston. Columbo and Neilson 
(1977) have recommended a maximum temperature of about $300 \mathrm{C}$ to avoid decomposition of the polymer.

A temperature limit for the waste form from the slagging pyrolysis incinerator at the Idaho National Engineering Laboratory has not yet been reported. The maximum temperature could be quite high, however, as the processing temperature of the incinerator is $1,650 \mathrm{C}$.

Jenks (1977) has recommended a maximum temperature limit of $400 \mathrm{C}$ for fused cladding and hardware wastes based on an observed increase in surface reaction rates at high temperatures.

As with fused cladding and hardware wastes, the surfaces of the Zircaloy hulls may become very reactive in the compressed cladding and hardware waste form as a result of the degradation of the protective oxide film. However, as the area-to-volume ratio of these wastes will be much larger than for the fused wastes, and accordingly, the possibilities for rapid surface reactions will be greater, Jenks (1977) suggests a temperature 1imit of $200 \mathrm{C}$.

Jenks (1977) has noted that high-fired, $1,000 \mathrm{C}, \mathrm{PuO}_{2}$ is very refractory and is difficult to dissolve by normal techniques. Also, its vapor pressure is very low, $\ll 10^{-10} \mathrm{~atm}$ at $500 \mathrm{C}$. Accordingly, he has recommended a temperature constraint of $500 \mathrm{C}$.

Some of the solid waste forms developed for gaseous fission products are silver zeolite, calcium carbonate, metal matrices, and polymer matrices. Temperature limits for these waste forms, however, have not yet been estab11shed (Mi11er and Wurm, 1980).

Table 2-2 lists the recommended maximum canister temperatures. Jenks (1977) gives the only source of maximum canister temperatures based on actual structural changes. Other sources recommend maximum 
Table 2-2. Recommended Maximum Canister

Temperatures

\begin{tabular}{lrl}
\hline Canister & Maximum Temperature, C \\
\hline 304L Stainless Steel & $375 \quad$ (Jenks, 1977) \\
Carbon Stee1 & $375 \quad$ (Jenks, 1977) \\
\hline
\end{tabular}

canister temperatures, usually 300 to $500 \mathrm{C}$, designed to limit the corrosion rate of the canister should it come in contact with ground water.

Using austenitic stainless steel, probably $304 \mathrm{~L}$, as his canister material, Jenks (1977) noted that it underwent structural changes during long-term exposure in air at temperatures in the range of 400 to $900 \mathrm{C}$. The observed effect is an increased susceptibility to stress cracking when the steel is subsequently exposed to aqueous solutions. Jenks also noted that carbon steel is probably less susceptible to significant changes in structure and corrosion during long-term heating at temperatures greater than $400 \mathrm{C}(1977)$. Not having any information to confirm this, however, he chose the same temperature limit for carbon steel as for austenitic stainless steel, $375 \mathrm{C}$ for five year retrievable geologic storage.

Table 2-3 1ists some recommended maximum backfill temperatures. In the multibarrier system the backfill has two major functions:

- To minimize contact between the waste package and the host rock

- To control the release of radionuclides into the host environment in the event of containment failure by the previous barriers. 
The first function of the backfill can be further divided into two areas. First, the backfill is required to minimize contact between the waste package and the ground water to prevent any corrosion. Second, the backfill must protect the waste package from the impact of falling rock and from undue stress resulting from minor bedrock movement. The important backfill properties are permeability, bearing capacity, shear strength, plasticity, and sorption.

Table 2-3. Recommended Maximum Backfil1 Temperatures

\begin{tabular}{lll}
\hline Backfill Material & Maximum Temperature, C \\
\hline Bentonite & $100 \quad$ (Smith, 1980) \\
$300 \quad$ (Miller and Wurm, 1980) \\
Zeolite & $300 \quad$ (U.S. Department of Energy, 1979) \\
\hline
\end{tabular}

Bentonite has been extensively studied by Swedish scientists as a potential backfill material. However, they have expressed concern over the physical and chemical stability of pure bentonite in a repository environment at temperatures over $100 \mathrm{C}$ (Ahlstrom, 1979). Miller and Wurm (1980), on the other hand, report that bentonite retains its properties to at least $300 \mathrm{C}$. Zeolites have also been proposed as a backfill material primarily because of their high-cation-exchange capabilities. Unfortunately, zeolites lose their water and therefore their cation-exchange capacity at temperatures well below $300 \mathrm{C}$ (Miller and Wurm, 1980). 


\subsection{NEAR FIELD}

The primary concern in the near field is the stability of the rooms and pillars as judged by the media temperatures and the rock strength-to-stress ratios. For a repository in salt this usually translates into an acceptable amount of creep, whereas in nonsalt repositories this usually corresponds to minimizing the possibility of failure by rock fracturing. The influencing factors include:

- The average waste emplacement density

- The time-dependent heat generation rate

- The average depth of the heat sources relative to the storage room floor

- The host rock thermal and mechanical properties, and

- The in situ stresses in the formation due to the geologic structures .

The above parameters and ventilation conditions also determine the personnel working conditions.

Table 2-4 1ists the recommended peak media temperatures for salt, granite, basalt, and shale. A recommended maximum temperature for tuff was not found.

Cheverton and Turner (1972), in a study where the repository medium was bedded salt, specified a thermal constraint on the basis of a unit cell. They stated that no more than 1 percent of the salt volume in this unit cell should be at a temperature above $250 \mathrm{C}$. This limit was based upon experimentally observed decrepitation (fracturing) of the salt above $250 \mathrm{C}$. Jacobsson (1977) concluded from laboratory tests done on several unconfined rock samples from several locations 
Table 2-4. Recommended Maximum Media Temperatures

\begin{tabular}{lll}
\multicolumn{1}{c|}{ Medium } & Maximum Temperature, C \\
\hline Salt, bedded or domed & $250 \begin{array}{l}\text { (U.S. Department of Energy, } \\
1980)\end{array}$ \\
Granite & $350 \begin{array}{l}\text { (U.S. Department of Energy, } \\
1980)\end{array}$ \\
Basalt & $350 \begin{array}{l}\text { (U.S. Department of Energy, } \\
1980)\end{array}$ \\
Shale & $250 \begin{array}{l}\text { (U.S. Department of Energy, } \\
1980)\end{array}$ \\
\hline
\end{tabular}

that the decrepitation temperature of salt was between 260 and $320 \mathrm{C}$. Samples from other locations, however, did not show any decrepitation when heated to $400 \mathrm{C}$. Jacobsson (1977) has also recommended a limit of $350 \mathrm{C}$ for granite and basalt, although a good basis for determining the maximum permissible temperature for hard rocks has not yet been established. For shale, a maximum of $250 \mathrm{C}$ may be reasonable although, as with hard rocks, a good basis for determining the maximum permissible temperature has not been established.

J. E. Russell (1977), studying salt as a possible repository medium, defined a constraint based on stress and mine geometry parameters. From this thermomechanical analysis, Russe11, using as his criterion the amount of room closure that would still allow access to the rooms at the end of the retrievability period, set a limit on the room closure of 10 to 15 percent of the original room height (see Table 2-5). An earlier work by Cheverton and Turner (1972), also studying bedded salt, defined a near-field constraint based on a unit 
Table 2-5. Recommended Permissible Amounts of Room Closure in Salt

\begin{tabular}{cr}
\hline Medium & Permissible Amount of Room Closure, \% \\
\hline Bedded Salt & $10-15 \% \quad$ (Russe11, 1977) \\
Domed Salt & $10-15 \% \quad$ (Russe11, 1977) \\
\hline
\end{tabular}

cell. They stated that no more than 25 percent of the salt volume in the unt cell should exceed $200 \mathrm{C}$.

Near-field constraints have also been given in terms of strengthto-stress ratios for the rooms and pillars by Dames and Moore (1978) (see Table 2-6). Strength-to-stress ratios are a way of determining rock stability. If the strength-to-stress ratio is less than one, then there is a potential for fracture fallure according to the Mohr-Coulomb failure criteria. Should the strength-to-stress ratio be greater than one, however, then the rock mass should be mechanically stable. Dames and Moore considered three media types: granite, basalt, and shale. For a room in granite or basalt, they set a required strength-to-stress ratio of 2 within 1.5 meter of the opening to the room. Whereas for a room in shale, with continuous support, they set a required strengthto-stress ratio of 1 within 1.5 meters of the room opening. Dames and Moore also required a strength-to-stress ratio of 2 across the midheight of the pillars for pillar stability in granite, basalt, and shale.

The strength-to-stress ratios, shown in Table 2-6, and the permissible amounts of creep for salt, shown in Table 2-5, can be translated Into a recommended allowable waste emplacement density for a specified 
Table 2-6. Recommended Maximum Media Strengthto-Stress (s/s) Ratios

\footnotetext{
Medium

Strength-to-Stress Ratio

Granite

2 within $1.5 \mathrm{~m}$ of opening (Dames and Moore, 1978) and 2 across the pillar mid-height

Basalt

2 within $1.5 \mathrm{~m}$ of opening (Dames and Moore, 1978) and 2 across the pillar mid-height

Shale

1 with continuous support (Dames and Moore, 1978) within $1.5 \mathrm{~m}$ of opening and 2 across the pillar mid-height

medium and waste type, as shown in Table 2-7. J. E. Russe11 (1977) developed the suggested waste emplacement density for salt. The waste emplacement densities for basalt and shale by Science Applications, Inc. (1976), are actually two-thirds of their calculated density. The Management of Commercially Generated Radioactive Waste (U.S. Department of Energy, 1980) also suggests allowable waste emplacement densities for the various media and waste types. In calculating the emplacement densities shown in Table 2-7, the following assumptions were made:

- Waste emplaced 10 years after removal from reactor

- The repository is loaded simultaneously and instantaneously

- Effects of stress upon thermal properties were not included

- Presence of water was neglected in the thermal analysis

- Only simplified horizontal stratigraphies were assumed.
} 
Table 2-7. Recommended Average Waste Emplacement Density, $\mathrm{kW} / \mathrm{ac} r e$

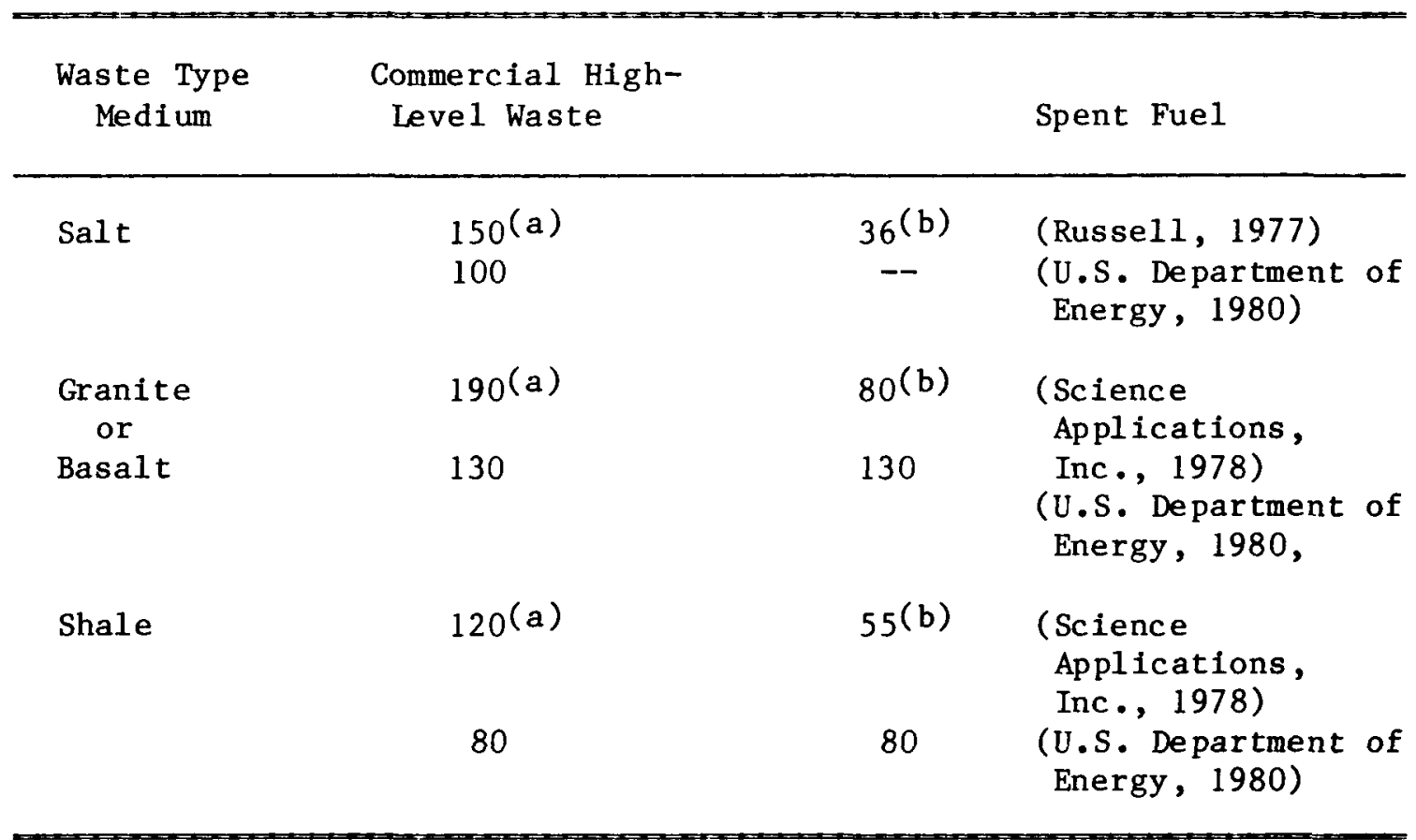

(a) Average waste emplacement density for 5-year retrievability.

(b) Average waste emplacement density for 25-year retrievability.

During waste emplacement and retrieval operations the working conditions of the personnel will be of concern. Kaiser Engineers (1980) recommends a maximum air temperature of $50 \mathrm{C}$ for retrieval operations in unsealed rooms. For retrieval operations in rooms that have already been backfilled, however, they recommend a maximum air temperature of $28 \mathrm{C}$, see Table 2-8. The National Institute for Occupational Safety and Health (NIOSH) (1972), recommends a WBGT (wet-bulb globe temperature) of $26 \mathrm{C}$ be maintained in the repository room during the retrieval operations. The WBGT is a physiological heat stress index adopted by NIOSH which reflects the combination of air temperature, humidity, radiation, and wind speed. A rock temperature of $49 \mathrm{C}$ has been suggested as the highest desirable temperature for the safe operation 
Table 2-8. Recommended Maximum Working Temperature

\begin{tabular}{lll}
\hline \multicolumn{1}{c}{ Working Conditions } & Maximum Temperature, C \\
\hline $\begin{array}{l}\text { Retrieval operations in } \\
\text { unsealed rooms }\end{array}$ & $50 \quad$ (Kaiser Engineers, Inc, 1980) \\
$\begin{array}{l}\text { Retrieval operations in } \\
\text { rooms from which backfill } \\
\text { has been removed }\end{array}$ & $28 \quad \begin{array}{l}\text { (Kaiser Engineers, Inc., 1980) } \\
\end{array}$ \\
\hline
\end{tabular}

of retrieval equipment by the Mine Design Study Working Group (MIDES-WG) of Sandia National Laboratories in its 1980 activity work package on blast cooling and continuous cooling.

\subsection{FAR FIELD}

The primary concern in the far field is to maintain the physical, chemical, and hydrologic integrity of the host rock and the overlying stratigraphy. Another major concern is to limit the temperature rise in the aquifers and at the surface of the earth. The influencing factors for this region include:

- The average waste emplacement density

- The long-term time dependence of the heat generation rate, and

- The average far-field thermal properties.

By assuring the integrity of the formation a long-term barrier between man and the environment and the radioactive waste is provided.

By defining the minimum strength-to-stress ratio required to maintain the stability of the far-field rock the physical integrity of the formation can be assured. Table 2-9 1ists the currently recommended strength-to-stress ratios for domed salt, bedded salt, granite, basalt, 
Table 2-9. Recommended Maximum Strengthto-Stress Ratio

\begin{tabular}{|c|c|}
\hline Medium & $\begin{aligned} \text { Strength-to-Stress Ratio - } & \text { NWTS Working } \\
& \text { Group } \\
& \text { on Far-Field } \\
& \text { Performance } \\
& \text { Constraints }\end{aligned}$ \\
\hline Bedded Salt & $>1$ in the aquitards \\
\hline Domed Salt & $>1$ in the aquitards or caprock \\
\hline $\begin{array}{l}\text { Granite } \\
\text { Tuff }\end{array}$ & $\begin{array}{l}>1 \text { in the middle } 70 \% \text { of the rock column } \\
\text { lying between the repository horizon } \\
\text { and ground surface }\end{array}$ \\
\hline Basalt & $>1$ everywhere in the far field \\
\hline
\end{tabular}

and tuff developed by the NWTS Working Group on Far-Field Performance Constraints in its draft on repository performance constraints in the far-field domain. To determine the strength-to-stress ratios in Table 2-9, the in situ stress, mechanical properties, constitutive law, and initial temperature gradient in the formation must be known.

In general, the changes in stress in a formation caused by repository excavation and the thermal energy release, are compressive in nature. Therefore, there is a potential for shear failure in those regions where the rock mass shear strength is exceeded. For granite and tuff it has been suggested that the strength-to-stress ratio be greater than one in the middle 70 percent of the rock mass between the repository and the surface, see Figure 2-1 from the NWTS Working Group on Far-Field Performance Constraints draft. For basalt it has been recommended that the strength-to-stress ratio be greater than one everywhere in the far-field region. This is to ensure that the repository basalt flow remains intact. For bedded and domed salt it 


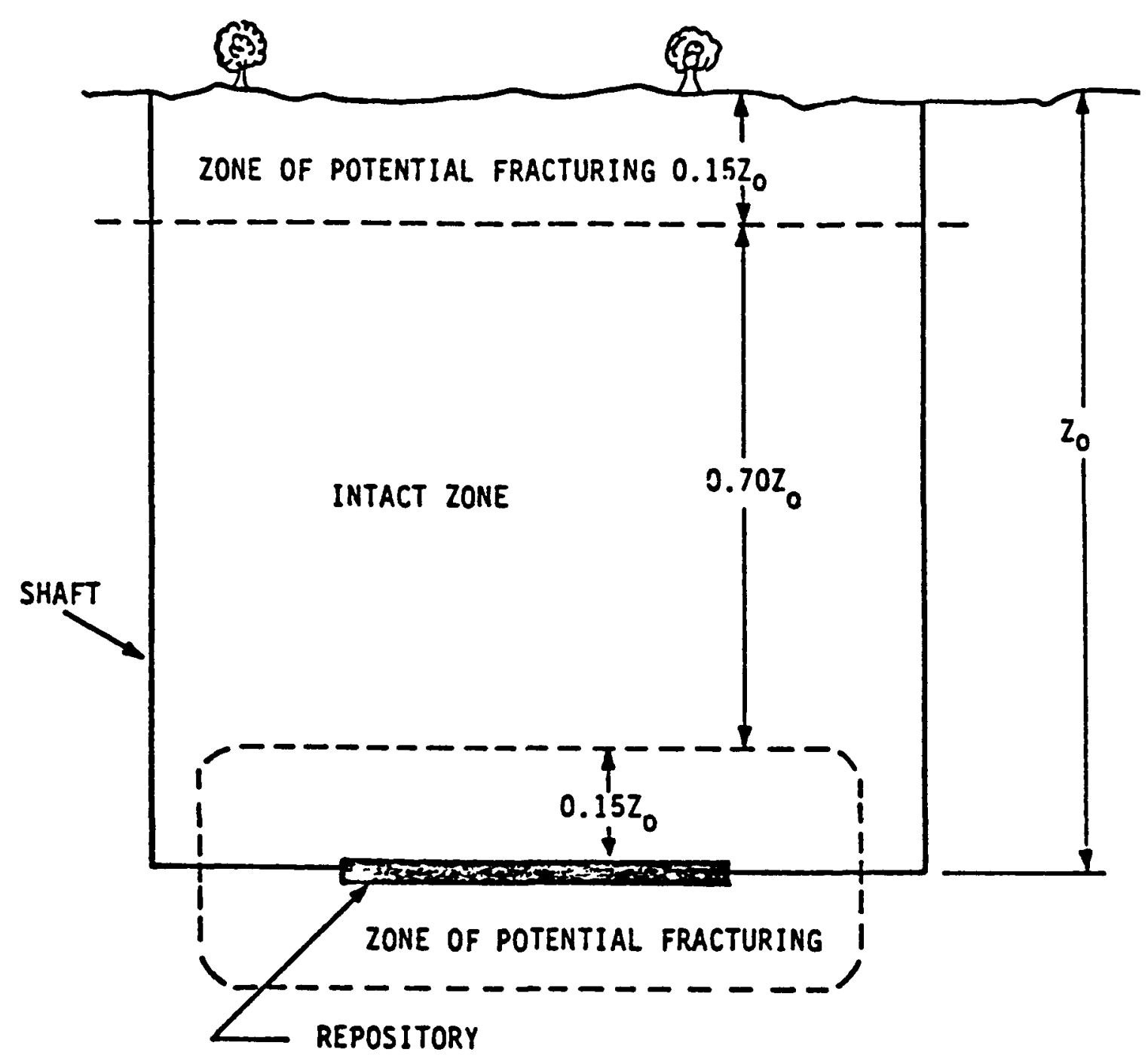

FIGURE 2-1. SCHEMATIC CROSS SECTION OF A REPOSITORY IN GRANITIC ROCK SHOWING ZONES OF POTENTIAL FRACTURING (NWTS WORKING GROUP ON FAR-FIELD PERFORMANCE CONSTRAINTS) 
has been recommended that the strength-to-stress ratio be greater than one in the aquitards or caprock.

A related parameter, known as the perturbed fissure zone, also has been defined by the NWTS Working Group on Far-Field Performance Constraints. As the rock mass undergoes thermal expansion, horizontal tensile stresses may be established in a zone near the surface. These tensile forces have the potential for opening vertical fractures, hence the name--the perturbed fissure zone. Consequently, it has been recommended that the maximum vertical extent of the perturbed fissure zone should not extend downward from the surface more than 15 percent of the repository depth in any medium.

Another parameter used to gage the far-field rock stability is the amount of vertical displacement, uplift, or subsidence experienced by the ground surface during the thermal period. Table 2-10 lists two recommendations for the maximum permissible vertical displacement. It should be noted that it is possible to meet the maximum vertical displacement limit and still fracture an underlying layer.

Table 2-10. Recommended Maximum Vertical Displacement

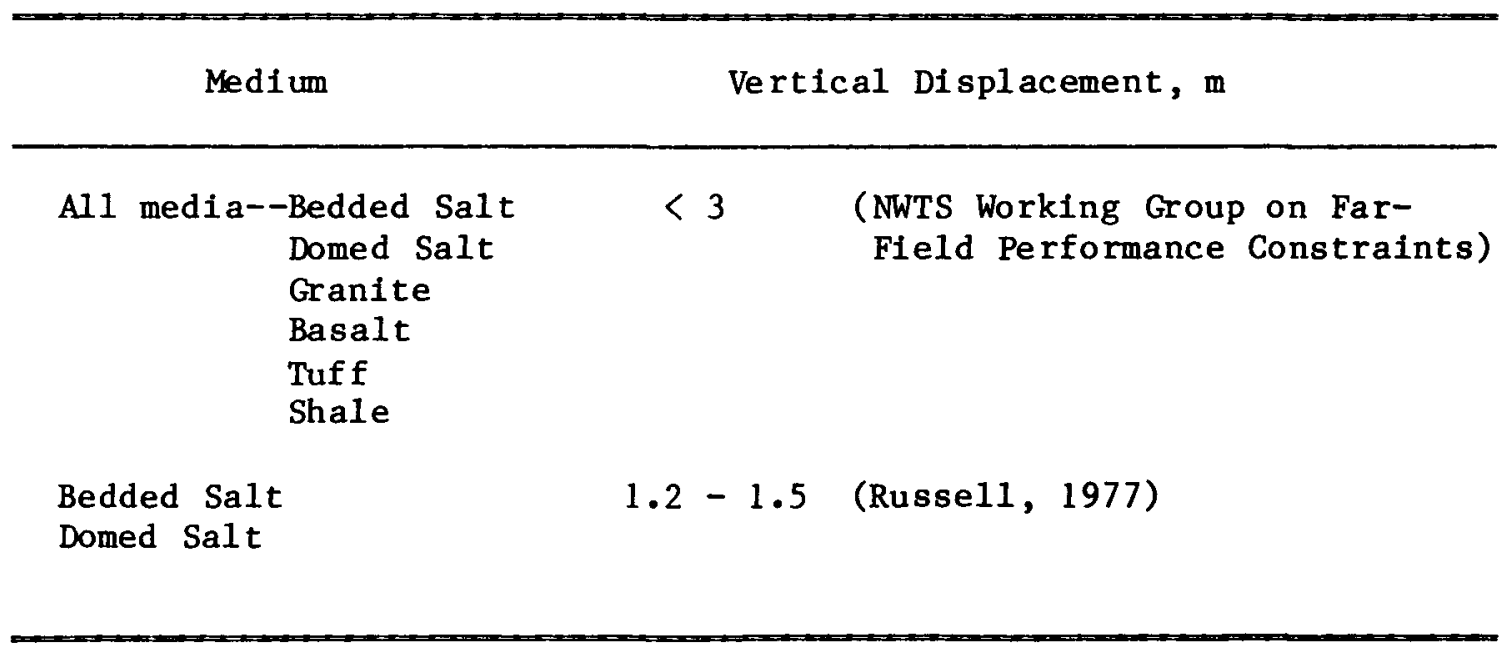


The NWTS Working Group on Far-Field Performance Constraints, in its draft on repository constraints on the far-field doma1n, recommends a maximum vertical displacement of less than 3 meters. They required the maximum vertical displacement to be less than those variations which occur by natural processes such as glacial rebound and erosion. Also, the vertical displacement must take place in a relatively smooth fashion.

J. E. Russe11 (1977) recommended a tentative range of 1.2 to 1.5 meters for the maximum permissible uplift over a repository. The 1.2 to 1.5 meter 1 imit was based upon the assumption that rock-mass movements due to uplift would not be any worse than movements caused by subsidence over mines in sedimentary rocks, which are sometimes twice the suggested limit.

Because of the key role the shafts play in the operation of a repository, it is important that they maintain their integrity and suffer no deformations. After repository closure the main concern will be the long-term integrity of the shafts and borehole seals with regard to ground-water leakage. Table 2-11 1ists some possible shaft and borehole constraints which are related to the thermal energy release of the emplaced wastes.

In order to preserve the natural flora and in general protect the biosphere some attempts have been made to determine the maximum permissible temperature rise at or near the ground surface, see Table 2-12. Science Applications, Inc. (1978) has recommended a maximum temperature rise of $0.5 \mathrm{C}$ at the surface. The NWTS Working Group on Far-Field Performance Constraints also has suggested the maximum temperature increase within 3 meters of the ground surface be less than $4 \mathrm{C}$. 
Table 2-11. Recommended Shaft and Borehole Constraints

\begin{tabular}{|c|c|}
\hline Medium & $\begin{aligned} \text { Constraint - } & \text { NWTS Working Group on Far- } \\
& \text { Field Performance } \\
& \text { Constraints }\end{aligned}$ \\
\hline $\begin{array}{l}\text { Al1 media-- } \text { Bedded Salt } \\
\text { Domed Salt } \\
\text { Granite } \\
\text { Basalt } \\
\text { Tuff } \\
\text { Shale }\end{array}$ & $\begin{array}{l}\text { 1) The shaft and its components undergo } \\
\text { no fracturing due to thermo- } \\
\text { mechanical stresses and no signifi- } \\
\text { cant water leakage. } \\
\text { 2) Deformation of shafts and shaft } \\
\text { liners be small enough not to } \\
\text { interfere with operations or require } \\
\text { remedial repair work. }\end{array}$ \\
\hline $\begin{array}{l}\text { Basalt } \\
\text { Bedded Salt } \\
\text { Domed Salt }\end{array}$ & $\begin{array}{l}\text { During postclosure the permeability of } \\
\text { sealed shafts and boreholes be the same } \\
\text { as the aquitards in zones where } \\
\text { aquitards are intersected. }\end{array}$ \\
\hline $\begin{array}{l}\text { Granite } \\
\text { Tuff }\end{array}$ & $\begin{array}{l}\text { During postclosure the effective } \\
\text { permeability of sealed shafts and } \\
\text { boreholes be approximately the same } \\
\text { as the host rock permeability for } 70 \% \\
\text { of the vertical column between the } \\
\text { repository and the surface. }\end{array}$ \\
\hline
\end{tabular}

Table 2-12. Recommended Maximum Surface Temperature Rise

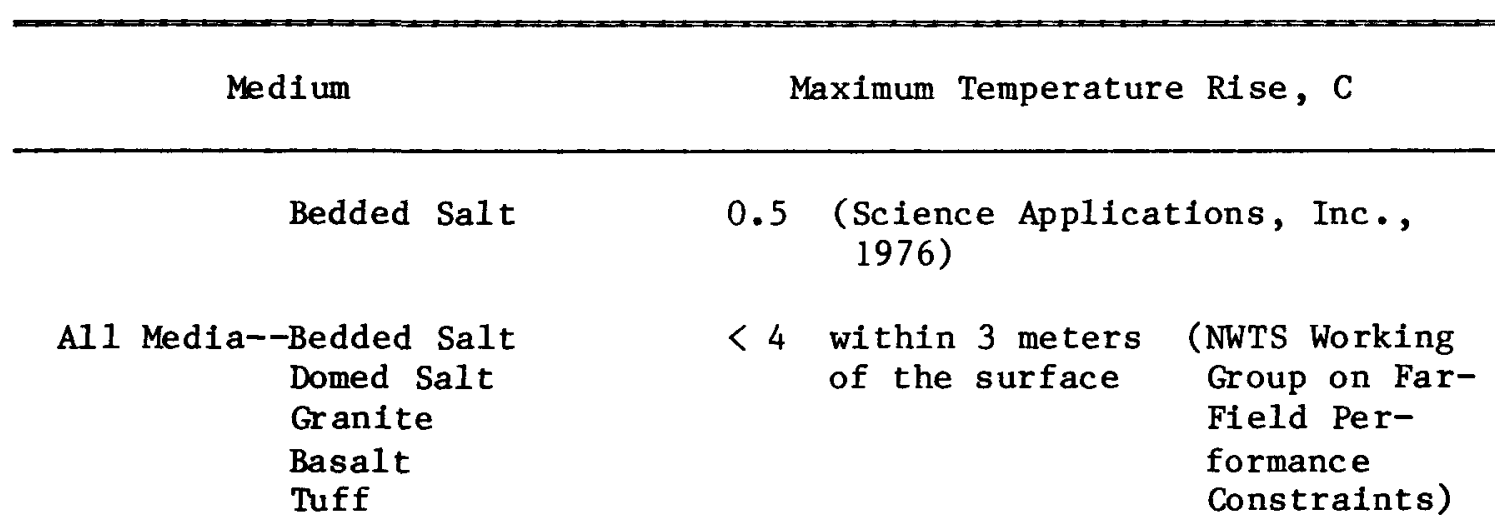


This limit was derived from comparison to a natural analogue, the Marysville geothermal area. From limited environmental studies, it appears that the region has not suffered any environmental damage as a result of the higher heat flux there. Both recommended temperatures are well within the daily, seasonal, and geographical temperature variations in the United States.

Temperature rise in aquifers is also a concern because the flow velocity could concelvably carry the higher temperature water outside the repository area. Also, temperature rises and temperature gradients can influence ground-water flow patterns which could provide a transport mechanism for the radionuclides. Table 2-13 1ists some recommended hydrologic constraints.

Science Applications, Inc. (1978), suggested a maximum temperature rise of $6 \mathrm{C}$ in the aquifers. The NWTS Working Group on Far-Field Performance Constraints, in its draft on repository performance constraints in the far-field domain, approached the problem on an overall basis by determining two ways in which the ground-water regime could be perturbed by the thermal energy release of the emplaced wastes. First, convection cells could be established, giving rise to an increase in the flow velocity and/or the development of a vertical component to the flow. Second, the thermomechanical stresses could alter the effective permeability of the rock mass. Consequently, the NWTS Working Group recommended that (1) no significant thermally induced convection cells contact the salt formation (bedded or domed) in which a repository is located; and (2) for granite, basalt, and tuff the transit time for ground water to travel from the repository to the surface as a consequence of thermal convective forces be greater than 1,000 years. 
Table 2-13. Recommended Hydrologic

\section{Constraints}

Medium

Constraint

All media--Bedded Salt

Domed Salt

Granite

6 C maximum temperature (Science

rise in aquifers

Applications,

Inc., 1976)

Basalt

Tuff

Shale

Bedded Sa1t

Domed Salt

Basalt

Granite

Tuff
No significant thermally induced convection cells contact the salt formation in which the repository is located

The transit time for ground water to trave 1 from the repository to the surface as a consequence of thermal convective forces is greater than 1,000 years
(NWTS Working Group on FarField Performance Constraints)

(NWTS Working Group on FarField Performance Constraints)

Increased temperatures may also lead to chemical effects. Minerals may become unstable, and reactions may occur which reduce the volume or the radionuclide retention capability of the minerals. For nuclear waste disposal in salt the primary concern is the dissolution of the salt formation. For granitic rocks the micas can become unstable at as low as $350 \mathrm{C}$ (NWTS Working Group on Far-Field Performance Constraints). Clay minerals, occurring as clay seams in salt strata and as secondary minerals in igneous rocks, can undergo dehydration and other changes at temperatures as low as 100 to $200 \mathrm{C}$. Table 2-14 1ists some recommended media temperatures for geochemical stability. 
Table 2-14. Recommended Maximum Media Temperatures for Geochemical Stability

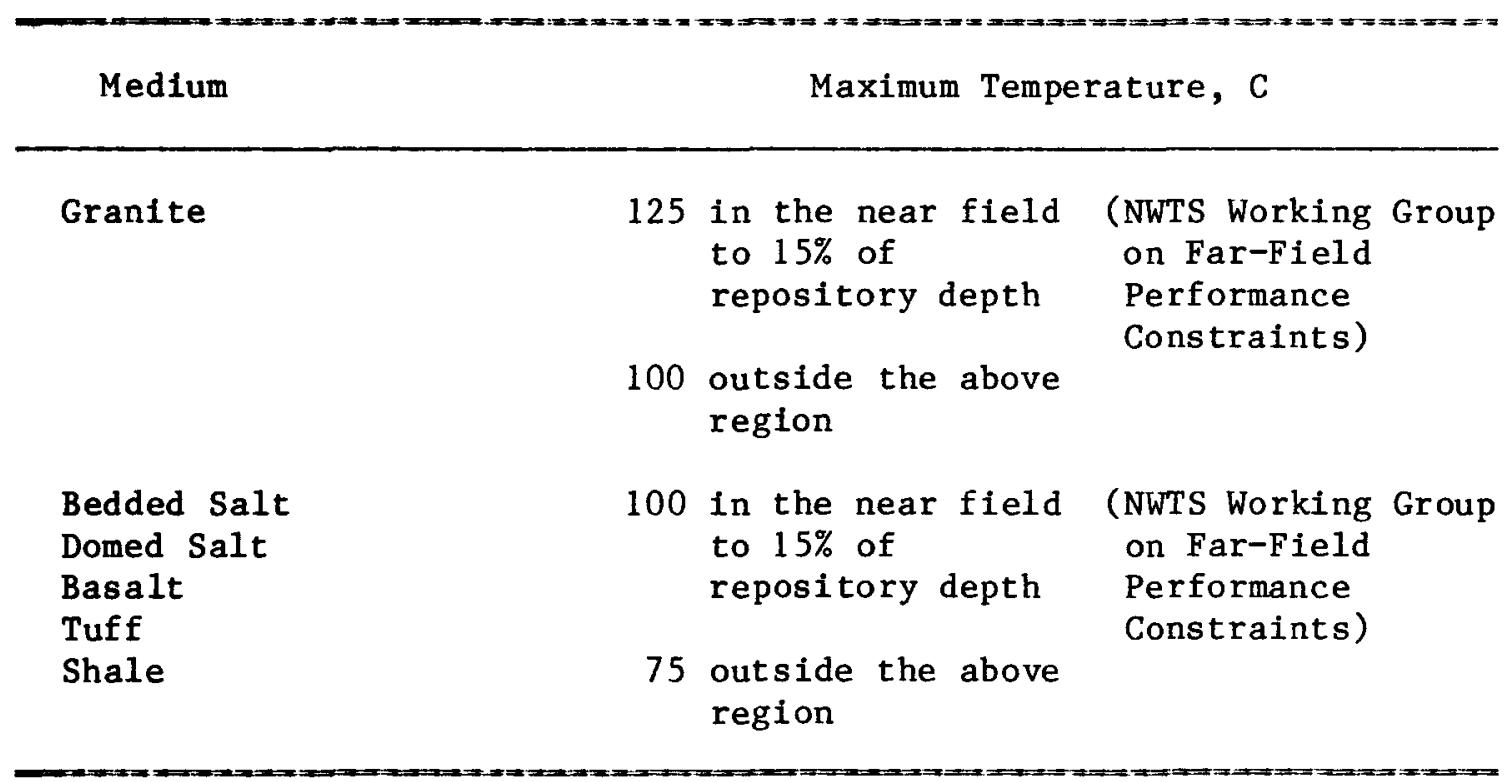

Based on the above constraints, waste emplacement densities for a spectfied waste type and medium can be determined (see Table 2-15). The following assumptions were made in calculating the emplacement densities:

- Repository is loaded simultaneously and instantaneously

- Effects of stress upon thermal properties were not included

- Presence of water was neglected in the thermal analysis

- Only simplified horizontal stratigraphies were assumed. 
Table 2-15. Recommended Average Waste Emplacement Density, $\mathrm{kW} / \mathrm{acre}$

\begin{tabular}{|c|c|c|c|c|c|c|}
\hline \multirow{2}{*}{ Medium } & \multirow{2}{*}{$\begin{array}{l}\text { Waste Type } \\
\text { Spent fuel }\end{array}$} & \multirow{2}{*}{$\begin{array}{c}\begin{array}{c}\text { Age of Waste } \\
\text { at Emplacement, } \\
\text { yr }\end{array} \\
5\end{array}$} & Emplacement & Density, & \multicolumn{2}{|c|}{$\mathrm{kW} / \mathrm{acre}$} \\
\hline & & & 67 & $\begin{array}{l}\text { (U.S. Department } \\
1980 \text { ) }\end{array}$ & of & Energy, \\
\hline & & 10 & 60 & (Russe11, 1977), & & \\
\hline & & & 40 & $\begin{array}{l}\text { (U.S. Department } \\
\text { 1980) }\end{array}$ & of & Energy, \\
\hline & & 50 & 20 & $\begin{array}{l}\text { (U.S. De partment } \\
\text { 1980) }\end{array}$ & of & Energy, \\
\hline & $\begin{array}{l}\text { High-level } \\
\text { waste }\end{array}$ & 50 & 54 & $\begin{array}{l}\text { (U.S. Department } \\
\text { 1980) }\end{array}$ & of & Energy, \\
\hline Shale & Spent fuel & 50 & 42 & $\begin{array}{l}\text { (U.S. De partment } \\
1980)\end{array}$ & of & Energy, \\
\hline
\end{tabular}




\section{A HIERARCHY OF THERMAL CRITERIA}

\subsection{AN OVERVIEW}

In order to understand the interrelationships among the various thermal criteria and to identify dominant criteria, a hierarchy of interaction was developed. The DOE/NWTS-33 series of documents (U.S. Department of Energy, 1981; 1982a, b, c) and the U.S. Nuclear Regulatory Commission (NRC) (1981) Proposed Rulemaking, 10 CFR Part 60, were used as a starting point in structuring the thermal criteria hierarchy. The DOE/NWTS-33 documents provide guidance to the National Waste Terminal Storage (NWTS) program in the form of "program objectives, functional requirements, performance criteria, and specifications intended to ensure that the program is consistent with national policy and that it results in the safe and environmentally acceptable disposal of radioactive waste". The NRC (1981) 10 CFR Part 60 specifies technical criteria for disposal of high-level radioactive wastes in geologic repositories.

The DOE/NWTS -33 criteria documents divide the mined geologic disposal system into three subsystems; the site, the repository, and the waste package. DOE/NWTS-33(1) addresses program objectives and criteria for the system as a whole. DOE/NWTS-33(2), (3), and (4) present the site, repository, and waste package performance criteria, respectively. The program objectives, as outlined in DOE/NWTS-33(1), are: 
- Effective waste isolation

- Institutional and societal acceptability

- Technical conservatism

- Multiple regional repositories

- Waste accommodation

- Effective resource utilization, and

- Use of near-term technology.

The criteria presented in DOE/NWTS-33(1) cover the system and subsystem functions and system performance. These criteria are summarized below.

- The system must provide for waste receipt and emplacement and must provide containment and isolation adequate to ensure no releases occur that might result in unacceptable doses to the public.

- The site must provide natural barriers to contain and isolate the waste and assist in keeping man away from the waste.

- The repository must provide for waste handling, emplacement, and retrievability; and contribute to long-term containment and isolation by enhancing the natural system through engineered barriers, providing monitoring, and providing measures to protect against human intrusion.

- The waste package must provide waste containment for a specified period and a long-term barrier to waste release into the geologic environment beyond that period.

- The system must satisfy NRC and EPA requirements for public health and safety and preserve the quality of the environment. 
Figure 3-1 shows the hierarchy of NWTS objectives, functional requirements, criteria, and specifications. Functional requirements establish the capabilities that the mined geologic disposal system must provide to achieve the program objectives. Performance criteria are designed to measure the performance of the disposal system and ensure that the functional requirements are met. Specifications will further define the performance for a particular site or design option.

As stated previously, the NRC's Proposed Rulemaking 10 CFR Part 60 specifies the disposal of high-level radioactive wastes in geologic repositories. It addresses the siting, design, and performance of a geologic repository, and the design and performance of the waste package. As with the DOE/NWTS-33 documents, the concept of multiple barriers is used to promote technical conservatism. The primary function of the waste package and underground facility is to control the release of radionuclides into the geologic environment. The present public draft criteria would require the engineered system to be designed so that the waste is contained within the waste package for the first 1,000 years following emplacement. After 1,000 years, the site must provide the primary barrier for the isolation of wastes from the environment. Figure 3-2 depicts a plausible pictorial representation of a geologic repository according to 10 CFR Part 60.

Both the DOE/NWTS-33 documents and the NRC's Proposed Rulemaking 10 CFR Part 60 follow the general guidelines of the Environmental Protection Agency (EPA). The current guidelines of the EPA call for the prompt disposal of radioactive wastes once adequate methods are available. Because they must be effective for so long, the EPA 


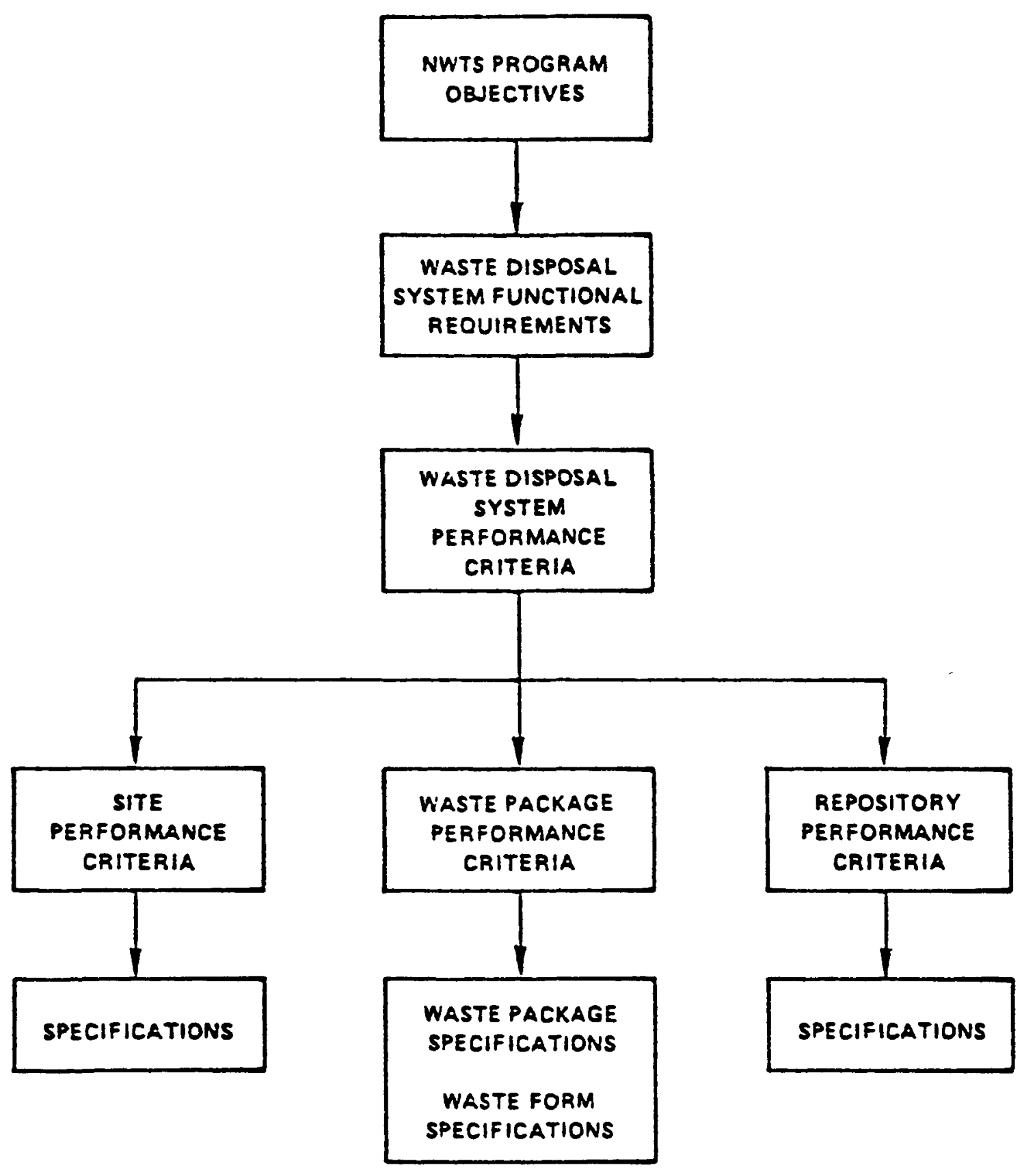

FIGURE 3-1. HIERARCHY OF OBJECTIVES, REQUIREMENTS, CRITERIA, AND SPECIFICATIONS (U.S. DEPARTMENT OF ENERGY, 1981; 1982a, b, c) 


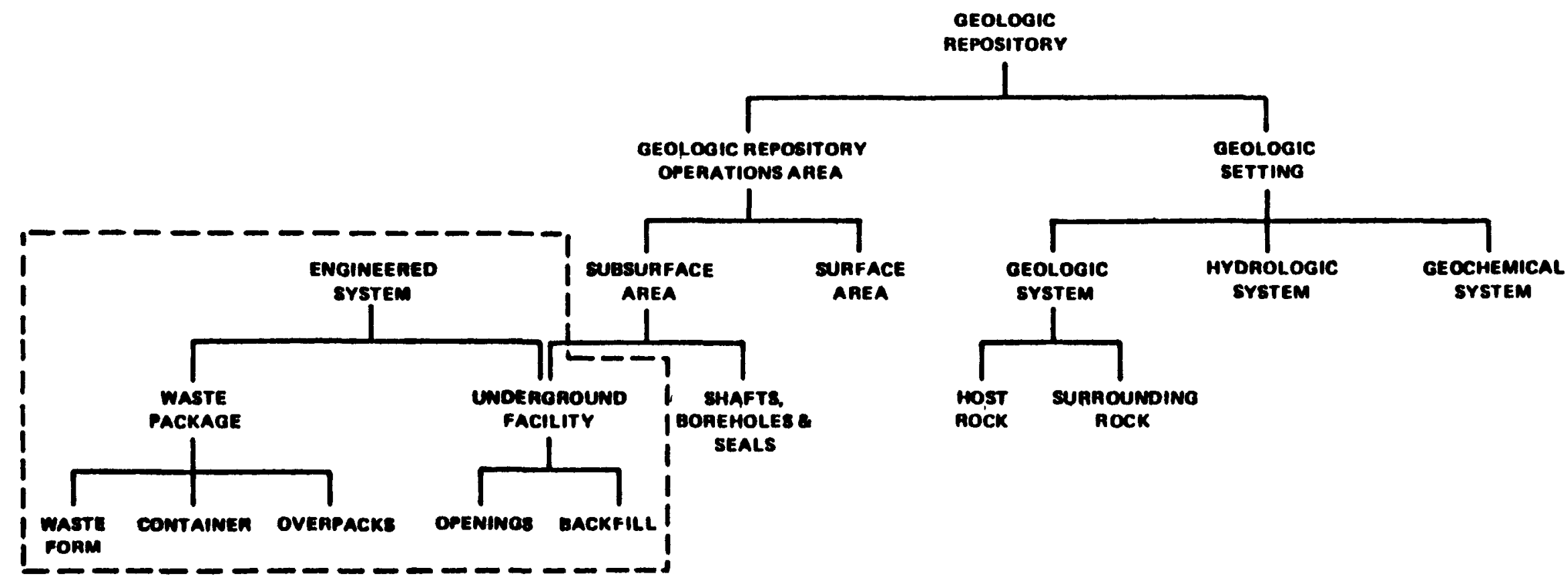

FIGURE 3-2. A PLAUSIBLE HIERARCHICAL STRUCTURE OF THE GEOLOGIC REPOSITORY ACCORDING TO 10 CFR PART 60 (U.S. NUCLEAR REGULATORY COMMISSION, 1981) 
requires disposal systems to offer as much protection as is reascnably achievable. Also, disposal systems should reduce the consequences of possible mistakes in selection, design, or construction by using several different types of barriers, both engineered and natural. Active institutional controls, while useful, should not be expected to last more than 100 years after disposal. The EPA guidelines are designed to cover radionuclide releases to the accessible environment for a period of 10,000 years after disposal.

To achieve the guidelines outlined in the DOE/NWTS-33 series of documents, the NRC's Proposed Rulemaking 10 CFR Part 60, and the EPA, an organized approach to analyzing the complex mined geologic disposal system is necessary. The draft document, "Nuclear Waste Disposal--A Description", which is still in preparation, is a first step toward realizing this need. It describes the development of a relevance tree for the nuclear waste disposal system. Relevance trees are simple graphical representations between a basic function and its subfunctions. These hierarchical structures are constructed by placing the highest order functions at the top of the tree and all visualized ways of accomplishing this basic function at the next level of the tree.

In the actual development of a relevance tree for the nuclear waste disposal systems, the draft document "Nuclear Waste Disposal--A Description" found it more meaningful to display the results in terms of wel1-known subsystems concepts. Nevertheless, the hierarchy was developed and arranged according to a logical decomposition of the system's functional requirements. Figure 3-3 shows how the primary 


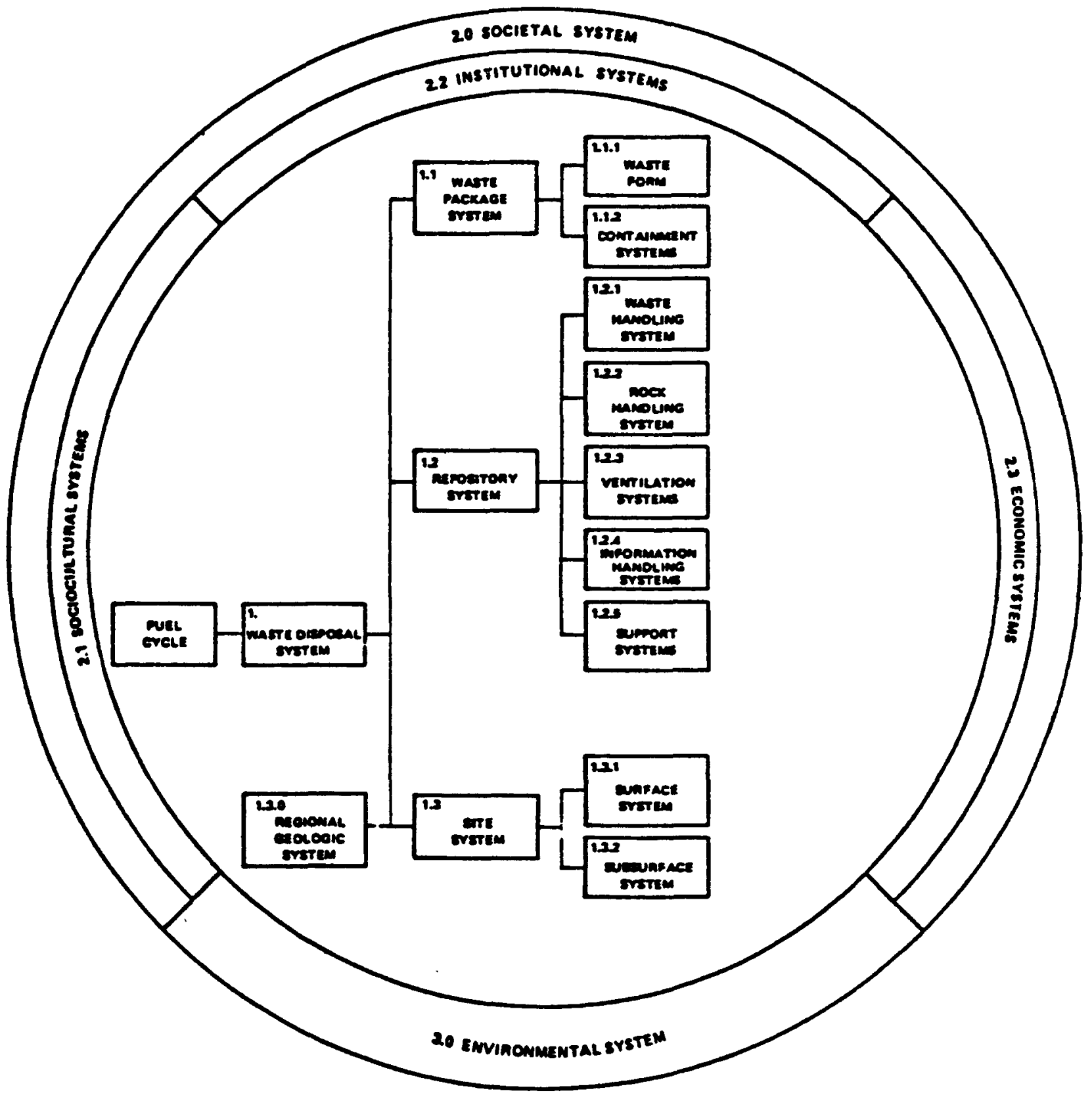

FIGURE 3-3. CONCEPTUAL STRUCTURE OF THE NUCLEAR WASTE DISPOSAL SYSTEM 
objective of the NWTS program, the long-term isolation of nuclear waste from the biosphere, can be broken down into the more specific functional requirements that must be provided by the subsystems of the nuclear waste disposal system.

In the draft paper, "Nuclear Waste Disposal--A Description", functional requirements are seen as simple statements of what the subsystem must do. They are derived from the next higher level system by specifying how the higher order function can be accomplished. A specific variable or parameter, known as a performance measure, is then used as an indication of how well the function is being performed. Closely tied to performance measures are performance criteria which explicitly define how well a subsystem must perform.

\subsection{DESCRIPTION OF THE THERMAL CRITERIA HIERARCHY}

A system is defined as a functionally related group of elements, whereas a hierarchy is a body of entities arranged in a graded series. Thus, for a system at any level in a hierarchy to function properly, all lower levels must function properly. Also, the functions required by a higher order system will appear as conditions or constraints on operation of lower order systems. Different system configurations at any leve1 will also influence the functions which the lower level must provide. Therefore, the hierarchy will become more and more specialized as different design options are chosen at each level. As can be seen from the DOE/NWTS-33 documents, the NRC's Proposed Rulemaking 10 CFR Part 60, the EPA guidelines, and the "Nuclear Waste Disposa1--A Description" draft working paper, there are several 
plausible hierarchical structures for a geologic repository. This situation exists because of the inconsistent use of many terms when discussing geologic disposal of radioactive wastes and especially when talking about system descriptions and hierarchies. To avoid any ambiguities in this paper a glossary of terms has been included in Appendix A. Some terms, however, are critical to understanding the following sections. They and their definitions follow:

- hierarchy - a body of entities arranged in a graded series

- system - a functionally related group of elements

- function - an assigned duty or activity

- criterion - a standard or rule on which a judgment or decision can be based

- constraint - something that restricts, limits, or regulates

- performance - the way in which something functions.

In order to determine the appropriate thermal criteria for the geologic disposal of radioactive waste, the impact of their thermal energy release on the disposal system must be evaluated. But to evaluate the possible problems, the geologic disposal system itself must be understood. Figure 3-4 defines the broad aspects of a mined geologic repository. The tasks of receiving, inspecting, and emplacing the waste are not included.

The first element in the hierarchy is the environmental system. This primary system includes man, his current and future activities, and the biosphere of which he is a part. It is this system which the mined geologic disposal system is designed to protect, although the actual linkage between the two is unclear, as represented by the dashed Iine. 
The mined geologic disposal system is a passive system with respect to the environmental system. The environmental system is controlled, to a limited extent, through institutional controls. These, however, will lose their effectiveness with time. The mined geologic disposal system, however, does have a direct influence on the lower systems in the hierarchy. By defining the geologic repository, constraints are immediately placed on any lower levels. This is true for any level in the hierarchy.

At each level in the hierarchy the lower systems are designed to allow the higher order systems to successfully complete their functions. Of necessity this responsibility to the higher order systems specifies the functions the lower order systems must perform. Figure 3-5 shows the nuclear disposal system in terms of the functions each element must fulfill.

The environmental system's primary function is to assure public health and safety by isolating existing and future nuclear waste, derived from both military and civilian activities, from the biosphere. The currently perferred method of accomplishing this goal is the concept of a mined geologic repository. As a result, the primary function of the mined geologic disposal system is the long-term isolation and containment of radioactive wastes in mined geologic repositories. The functions of all lower levels are thus generally defined, with the definition becoming more narrowed with each succeeding level.

As can be seen from Figures $3-4$ and 3-5 the mined geologic disposal system can be divided into three subsystems: the waste package system, the repository system, and the site system. The waste package 


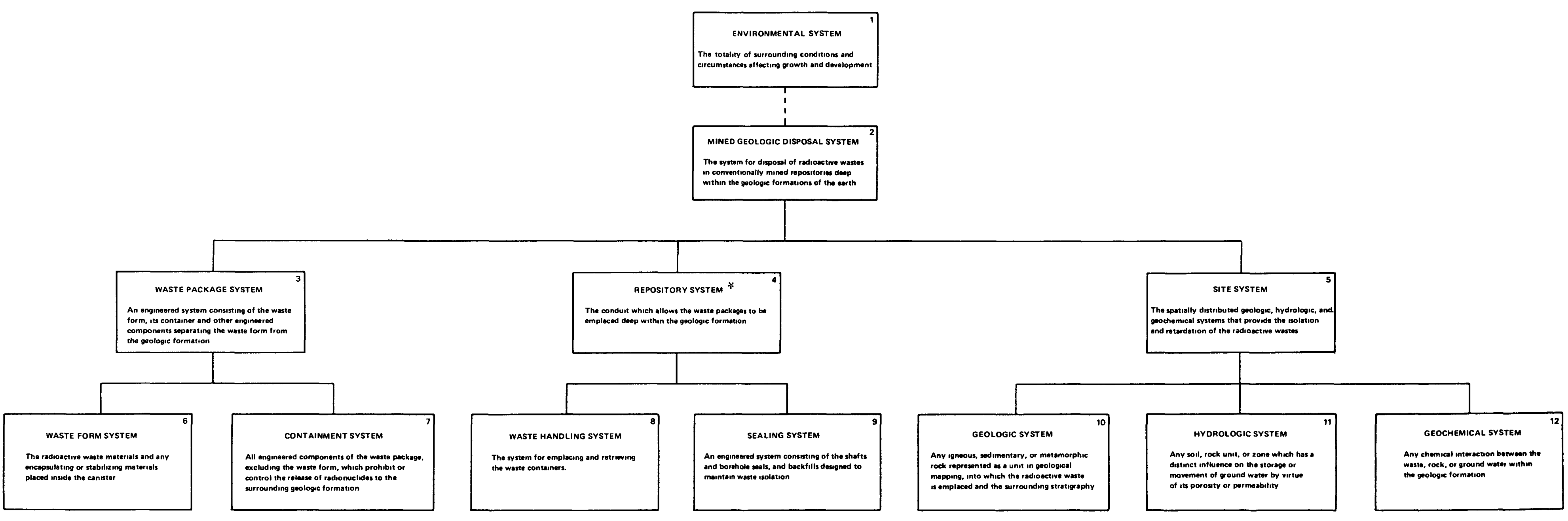

FIGURE 3-4. A HIERARCHY OF A MINED GEOLOGIC DISPOSAL SYSTEM

"Not all repository subsystems are shown. 
0 


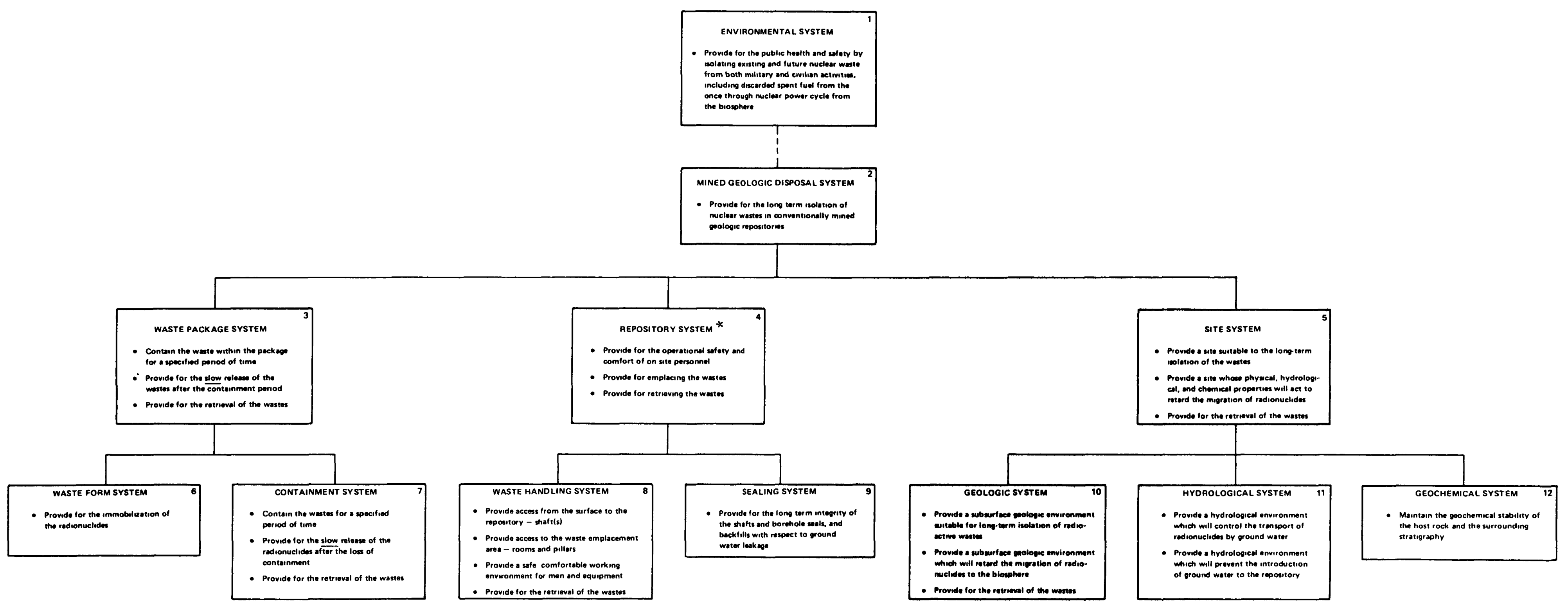

FIGURE 3-5. A HIERARCHY OF FUNCTIONS FOR A MINED GEOLOGIC DISPOSAL SYSTEM

-Not all repository subsystems are shown. 
O 0 
system consists of the waste form, the canister, any overpack materials, and backfills. Its main functions are to contain the wastes for a specified period of time, to provide for the slow release of the waste after the containment period, and if necessary to provide for the retrieval of the wastes. The repository system consists of the shafts, and the rooms and pillars. Its functions include emplacing and if necessary retrieving the wastes, and maintaining safe, comfortable working conditions for onsite personnel. The site system consists of the geologic formation and surrounding rock, the hydrologic regime, and the geochemical regime. Its primary function is to provide a site suitable for the long-term isolation of radioactive wastes, and whose physical, chemical, and hydrologic properties will act to retard the migration of radionuclides.

The following sections, $3.2 .1,3.2 .2$, and 3.2 .3 , will discuss in more detail the waste package system, the repository system, and the site system, respectively. These sections will explore the effects of the thermal energy release and suggest some possible thermal criteria along with the supporting reasons.

\subsubsection{Waste Package System}

The waste package system has been defined as an engineered system consisting of the waste form, its container, and any other engineered components separating the waste form from the geologic formation. As a system, the waste package has three functions: contain the waste within the package for a specified period of time, provide for the slow release of the wastes after the containment period, and provide for the retrieval of the wastes. 
The requirement for containment for a specified period of time is based on the decay characteristics of the wastes. This period is a function of the time the heat generated by the wastes is dominated by the decay of relatively short-1ived fission and activation products. During this period the toxicity of the fission products decreases by several orders of magnitude thereby mitigating, to some extent, the danger to man if the nuclides were to be transported to the biosphere. The requirement for retrievability arises from the recognition that some degree of uncertainty may exist in defining and implementing longterm isolation of radioactive wastes in mined geologic repositories. Currently proposed regulations would require, if adopted, a containment period of 1000 years with a limited release for the following 10,000 years at a nominal rate of less than one part in 10,000 per year and a retrieval option including the operational period plus 50 years (U.S. Nuclear Regulatory Commission, 1981).

The heat generated by the encapsulated wastes can endanger the effectiveness of the waste form, the canister, and any other engineered components as isolation barriers. To prevent this, the containment materials and the waste form should be maintained at sufficiently low temperatures to retard those effects which deteriorate the isolation barriers provided by the waste package. The waste package system can be divided into two lower order systems to facilitate the determination of these temperature limits. These two systems are the waste form system and the containment system. The waste form system consists of the radioactive waste materials and any encapsulating or stabilizing materials placed inside the canister. The containment system consists 
of all the engineered components of the waste package, excluding the waste form.

\subsubsection{Waste Form System}

The waste form system is represented as a hierarchy in Figure 3-6. (The following discussion will refer to Figure 3-6.) The function of the waste form system is to immobilize the radionuclides by containment as part of a solid. Several waste forms have been proposed, but with few exceptions, all fall into one of three categories: spent fuel, glass, or tailored ceramics. Although an acceptable geologic disposal system can probably be designed for any given waste form, the choice of waste form will affect the complexity, cost, feasibility, and size of a geologic repository.

Maximum allowable waste form temperatures will be different for the various waste forms. Maximum waste form temperatures are a function of the radionuclide content and specific activity of the package, the chemical composition and form of the waste, the package geometry, the characteristics of the engineered components of the package, the effective thermal conductivity of the geologic medium, and the characteristics of the heat sink. After emplacement of the waste package in the repository, the most likely vehicle for radionuclide release from the waste form into or through the package system and into the surrounding geology is intruding ground water. Waste form leaching, Item 2 in Figure 3.6, is therefore of primary concern when addressing waste mobilization. Before leaching by ground water can occur, physical and/or chemical reactions must occur to breach the engineered 
barriers of the containment system. These failure mechanisms will be discussed in the following section on containment systems.

The next level in the hierarchy identifies the primary release mechanisms of radionuclides. These release mechanisms occur with increased temperatures and will tend to decrease the leach resistance of the waste form and thereby increase the potential mobility of the waste. The failure mechanisms can be grouped into four general categories: alteration of the original chemical composition of the waste form, combustion of the waste form, volatilization of the waste form, and the loss of physical integrity of the waste form.

Item 3 of Figure 3-6 requires the maintenance of the original chemical composition and form of the waste form. Chemical composition is the complete description of the chemical compounds and their relative abundance which make up each waste form. The form describes how the waste has been immobilized, such as glass, spent fuel rods, or ceramics, to name a few. There are several possible failure mechanisms for the various waste forms in this catagory.

For spent fuel, there are two possible failure mechanisms under the chemical composition and form element in the waste form system hierarchy, as shown in Table 3-1 (Figure 3-6). The first failure mechanism is the oxidation of the ceramic fuel from $\mathrm{UO}_{2}$ to $\mathrm{U}_{3} \mathrm{O}_{8}$ with increased temperatures. This reaction has been shown to occur at $250 \mathrm{C}$ (Cordfunke, 1969). With the conversion of $\mathrm{UO}_{2}$ to $\mathrm{U}_{3} \mathrm{O}_{8}$ there is a large volume expansion which could crumble the uranium oxide to powder and split the Zircaloy cladding of the spent fuel. The presence of oxygen, however, which is required for this reaction to occur is not 


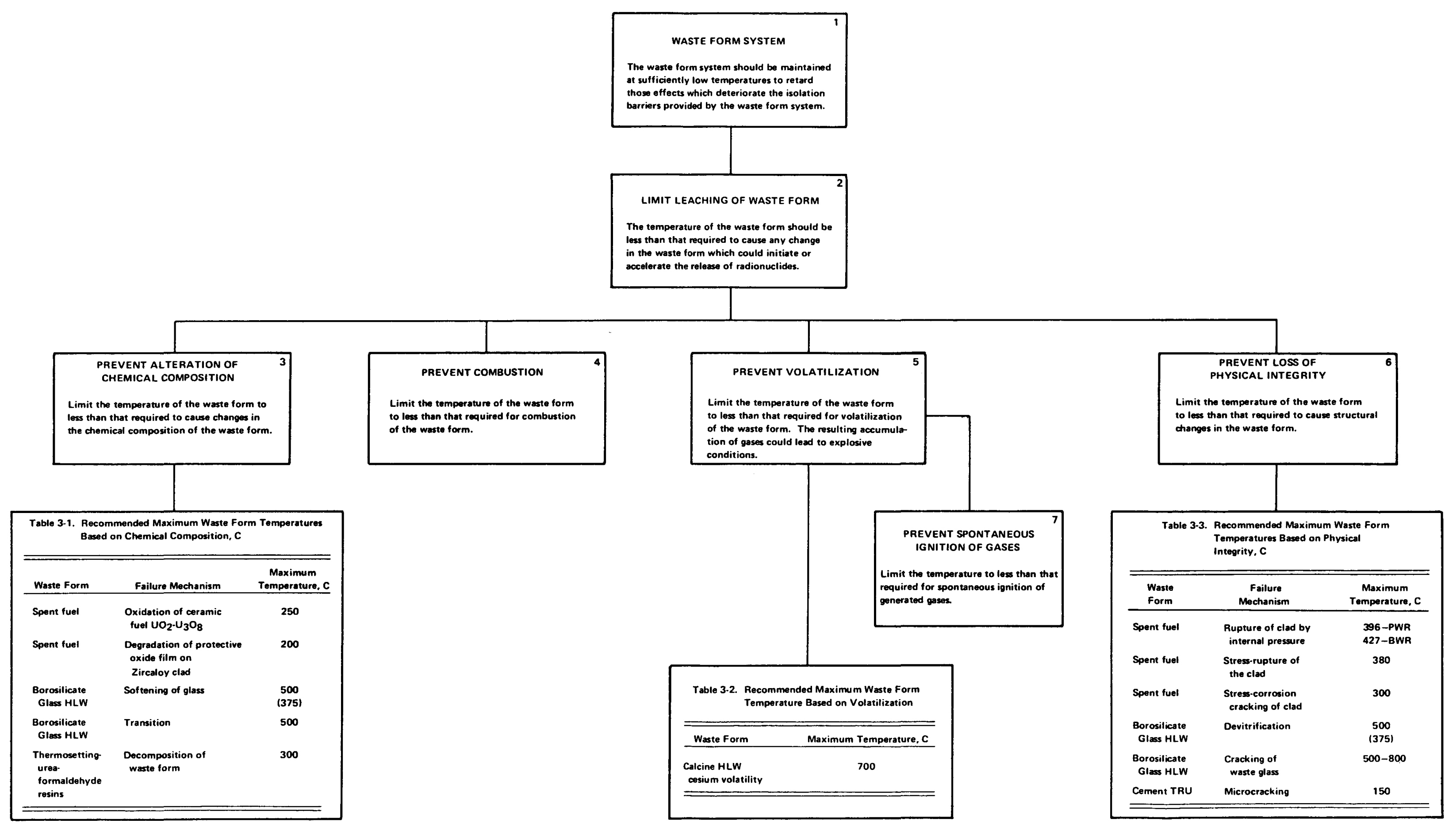

FIGURE 3-6. HIERARCHY OF WASTE FORM LIMITS 
expected to be abundant in the waste package. A maximum temperature of $250 \mathrm{C}$ is recommended to prevent this type of failure (Cordfunke, 1969). The second failure mechanism is the degradation of the protective oxide film on the Zircaloy cladding of spent fuel in the absence of an oxidant at elevated temperatures. This reaction has been reported to occur at $200 \mathrm{C}$ (Jenks, 1977). Pending additional work, Jenks has recommended a maximum of $200 \mathrm{C}$ to prevent this type of failure. Table 3-1 (Figure 3-6) also shows the possible failure mechanisms for borosilicate high-level waste through changes in the chemical composition and form. Both failure mechanisms are directly related to the temperature rise experienced by the waste glass. The transition temperature for borosilicate glass is $500 \mathrm{C}$, while the softening temperature occurs at a slightly higher temperature (Jenks, 1977). Borosilicate glass has been reported to flow easily at $900 \mathrm{C}$ (NWTS Working Group on Far-Field Performance Constraints in its draft on repository performance constraints in the far-field domain). At these temperatures there is concern that the migration of heavy, separable phases might occur. To prevent these failure modes from occurring a maximum temperature of $500 \mathrm{C}$ is suggested for borosilicate glass high-level waste (Jenks, 1977).

The two waste forms for transuranic waste which have a potential for failure in their chemical composition or form are thermosetting resins and urea-formaldehyde resins. Both fail through decomposition of their materials (Cohen et al, 1977, and Gilmore, 1977). A maximum temperature of $300 \mathrm{C}$ is, therefore, recommended for both thermosetting resins and urea-formaldehyde resins (see Table 3-1 of Figure 3-6) (Miller and Wurm, 1980). 
The last waste type in Table $3-1$ is cladding and hardware wastes. Compressed cladding and hardware wastes and fused cladding and hardware wastes are the two waste forms for this waste type. Both fail in the same manner, degradation of the protective oxide film in the Zircaloy cladding leading to an increase in surface reaction rates (Jenks, 1977). The fused waste form can tolerate higher temperatures, however, because of its smaller surface area-to-volume ratio. Based on this failure mechanism, maximum temperatures of $200 \mathrm{C}$ and $400 \mathrm{C}$ are recommended for the compressed and fused waste forms, respectively.

Item 4 of the waste form hierarchy (Figure 3-6) requires the prevention of the combustion of the waste form. The temperature at which combustion occurs is a function of particle size, surface area, and chemical composition and form. Once a fire has started, it promotes the mobility of the waste. Of the various waste forms, transuranic wastes are composed, either partly or entirely, of combustible materials .

Item 5 of Figure 3-6 requires the prevention of the volatilization of the waste form. This failure mechanism is related to the combustion failure mechanism in that the gases generated through volatilization of the waste form could experience spontaneous ignition. Thus, to avoid an explosive concentration of gases, it is necessary to restrict the maximum temperature to less than that required to volatilize any component of the waste form. At a temperature of $750 \mathrm{C}$, calcine commercial high-level waste has been reported to experience significant cesium volatility (Jenks, 1977). For this waste form, therefore, a maximum temperature of $700 \mathrm{C}$ has been recommended by Jenks (see Table 3-2 of Figure 3-6). 
Item 6 in the waste form hierarchy (Figure 3-6) requires the maintenance of the physical integrity of the waste form. As with the first element in the level, chemical composition and form, there are several failure mechanisms in this category, all of which are dependent on the waste type and waste form. Table 3-3 (Figure 3-6) lists some of the possible failure mechanisms as a function of waste type and form.

For spent fuel, there are three primary failure mechanisms under the physical integrity element in the waste form hierarchy. The first is the rupture of the clad by internal pressure (Blackburn et al, 1978). Fuel rod design for reactor service limits pressure-induced stress to less than $2 / 3$ the material yield stress or $1 / 2$ the material ultimate strength, whichever is lesser. Since the principal loading of fuel rod cladding comes from internal pressure, the relationship between this biaxial loading condition and the uniaxial loading conditions used to determine the material yield stress and the material ultimate strength must be established. Blackburn et al (1978) indicate that ratios of 1.1 and 1.0 are appropriate for biaxial to uniaxial yield stress and biaxial to uniaxial ultimate strength, respectively. Thus, service hoop stress level should be limited to $(2 / 3 \times 1.1)$ the material yield stress or $1 / 2$ the material ultimate strength, whichever is smaller. From this, Blackburn et al (1978) have shown that the maximum allowable temperature for PWR spent fuel is $396 \mathrm{C}$ and $>427 \mathrm{C}$ for BWR spent fuel (see Figure 3-7).

The second failure mechanism for spent fuel is the stress-rupture $(\mathrm{Sr})$ of the clad. Spent fuel rods stored at elevated temperatures are potentially susceptible to failure by stress-rupture since the internal pressure in the rod produces a tensile hoop stress in the cladding 

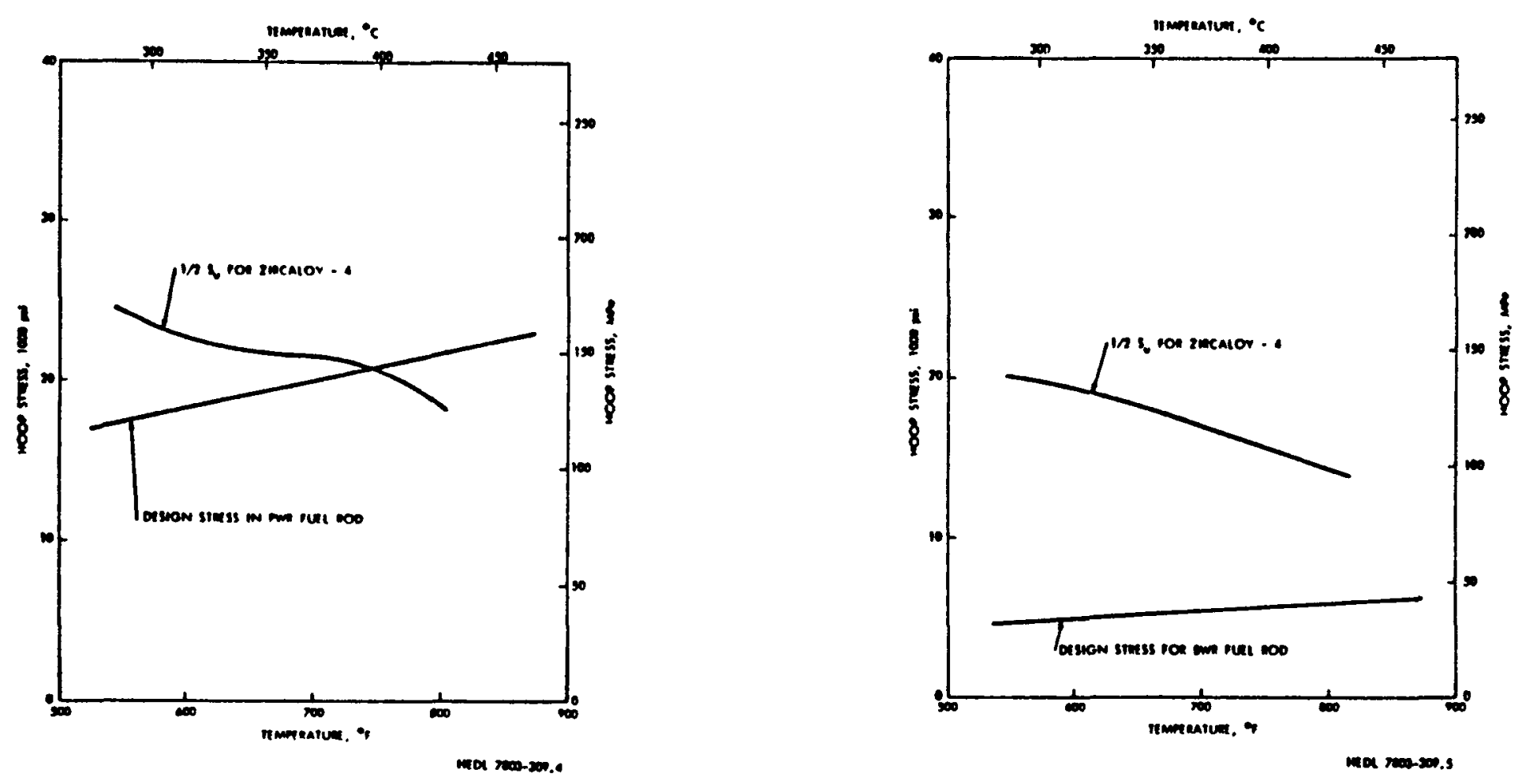

FIGURE 3-7. MAXIMUM ALLOWABLE TEMPERATURE TO AVOID RUPTURE OF FUEL ROD CLAD BY INTERNAL PRESSURE (BLACKBURN ET AL, 1978) 
wal1. Failure by stress-rupture is guarded against by restricting design stress levels to less than $2 / 3$ the minimum stress to produce rupture in some time, $t$. Using curves of $2 / 3 \mathrm{Sr}$ versus temperature, various storage conditions, and the design stress level curve, the diagram in Figure 3-8 can be constructed. From the points of intersection the maximum allowable cladding temperature for isothermal storage can be determined. Isothermal conditions, however, are not expected in dry storage of spent fuel because the decay heat varies over the storage life. The variation of decay heat and cladding temperature for a PWR assembly is shown in Figure 3-9. By using a creep damage rule the effect of varying the stress and temperature utilizing the isothermal stress-rupture data can be assessed. Figure 3-10 shows the accumulation of creep damage for various initial cladding temperatures. As the temperature decreases during storage, the rate of damage accumulation slows, so that indefinite storage is possible at a starting temperature of 380 C (Blackburn et al, 1978). Stress corrosion cracking is the third failure mechanism for spent fuel. The maximum allowable temperature for this failure mechanism is dependent on the initial flaw size. For flaw sizes that may be representative of as-fabricated cladding temperature, limits of $350 \mathrm{C}$ and $340 \mathrm{C}$ are obtained (B1ackburn et a1, 1978). The two crack sizes used were a $8 \mu \mathrm{crack}$ depth with a crack depth to crack length ratio 0.9 and a $8 \mu$ crack depth with a crack depth to crack length ratio of 0.2 , respectively. Cladding which has experienced pellet-cladding interactions during reactor service may have cracks extending halfway through the wall with an associated temperature limit of $250 \mathrm{C}$. 

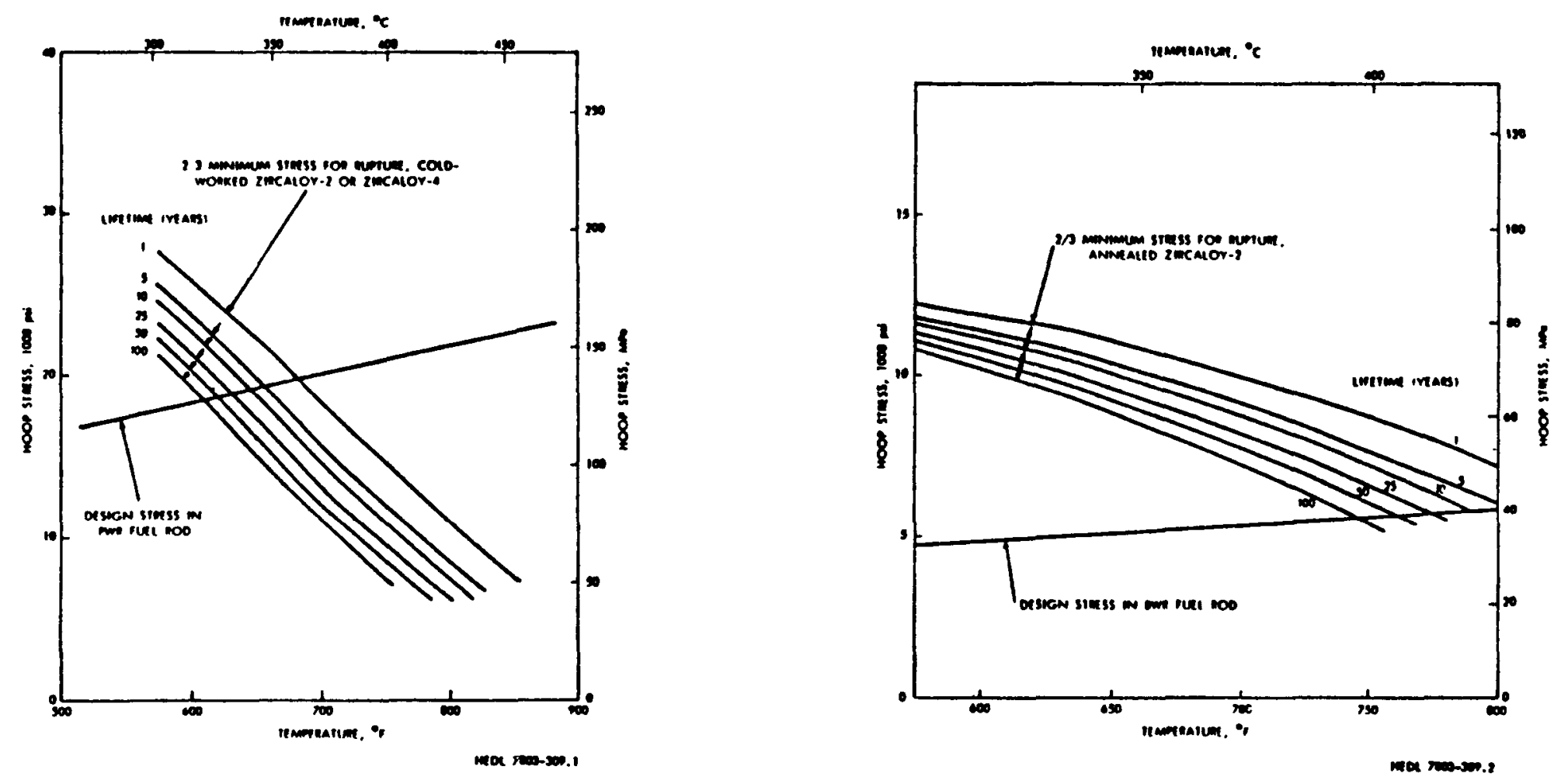

FIGURE 3-8. MAXIMUM ALLOWABLE TEMPERATURE FOR SPENT FUEL STORAGE AT CONSTANT TEMPERATURE (BLACKBURN ET AL, 1978) 


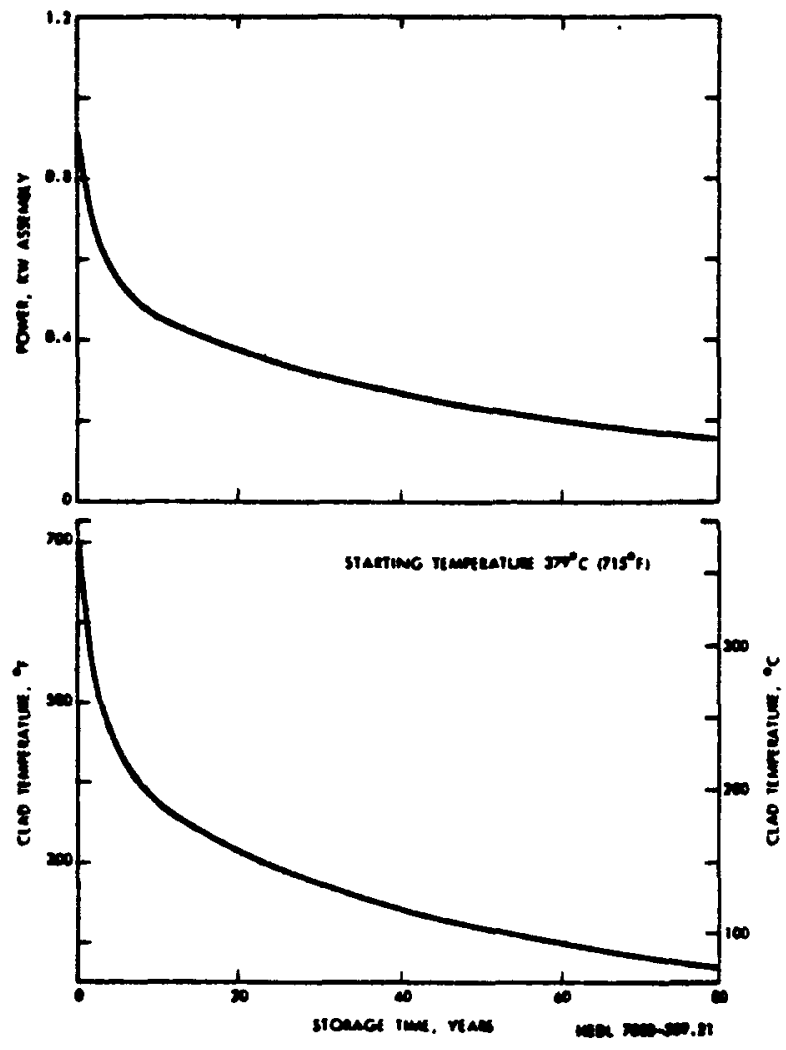

FIGURE 3-9. DECAY HEAT AND FUEL CLADDING TEMPERATURE AS A FUNCTION OF STORAGE TIME (BLACKBURN ET AL, 1978) 

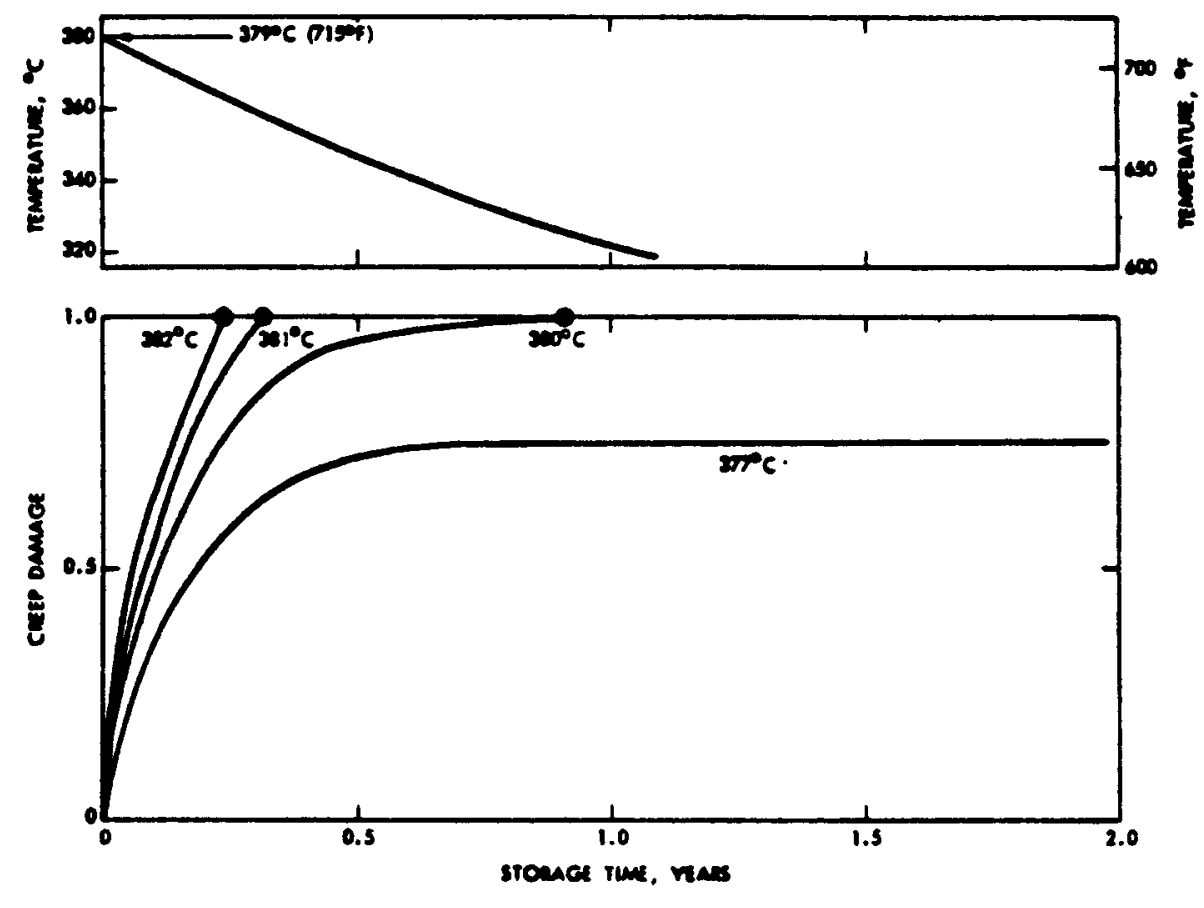

mes xom.2.

FIGURE 3-10. ACCUMULATION OF CREEP DAMAGE FOR VARIOUS STARTING TEMPERATURES (BLACKBURN ET AL, 1978) 
Based on this information, a maximum temperature of $300 \mathrm{C}$ has been recommended to avoid stress-corrosion cracking fallure (U.S. Department of Energy, 1980).

There are two possible ways in which borosilicate glass high-level waste can lose its physical integrity. These are devitrification and cracking of the waste glass. Devitrification is the transition of the molecular structure of glass from the amphorous to a crystalline state. The basic concern with this change is that devitrified glass will have a higher leach rate than glass which has not devitrified. A devitrification temperature of $500 \mathrm{C}$ has been reported for borosilicate highleve1 waste glass (Jenks, 1977).

A more recent study, however, has suggested the maximum temperature for waste glass should be set at $375 \mathrm{C}$ to avoid devitrification (Turcotte and Wald, 1978). The lower limit, $375 \mathrm{C}$, recommended when considerable devitrification in a zinc borosilicate waste glass, was observed to occur at times less than one year at a temperature of $500 \mathrm{C}$. As the rate of devitrification tends to be highest at the center of the waste glass where the highest temperatures are found, and lowest at the glass surface where leaching takes place, a maximum centerline temperature of $500 \mathrm{C}$ with a maximum surface temperature of 375 C is recommended to avoid devitrification (Jenks, 1977; Turcotte and Wald, 1978).

As mentioned previously, the second way for borosilicate highlevel waste glass to lose its physical integrity is through cracking of the glass at elevated temperatures. Significant increases in cracking and, therefore, in leach rates have been observed in test glasses heated for a few months in the range $500 \mathrm{C}$ to $800 \mathrm{C}$ (Jenks, 1977). 
Based on these tests a maximum temperature of $500 \mathrm{C}$ is recommended to avoid cracking of the waste glass.

Another waste form which can lose its physical integrity at elevated temperatures is cement transuranic waste. At elevated temperatures, cement has been shown to experience dehydration and thermal stresses which lead to microcracking and reduction in structural properties (American Society for Testing and Materials, 1978; Lokken, 1978). A maximum temperature of $150 \mathrm{C}$ is, therefore, recommended to avoid this form of failure.

\subsubsection{Containment System}

The containment system is represented as a hierarchy in Figure 3-11. (The following discussion will refer to Figure 3-11.) The function of the containment system is to contain the wastes for a specified period of time, to control the release of radionuclides after loss of containment, and to provide for the retrievability of the waste. Several engineered barriers actually make up the containment system. These include the canister, the overpack, the hole liner, and the backfill. The canister is the primary physical barrier to water intrusion following the thermal period. The overpack acts as a barrier to the intrusion of gruund water through the thermal period. Both the overpack and the hole liner provide a means for retrieving the waste should it become necessary or desirable. The backfill is the primary chemical barrier to radionuclide migration. It also acts to inhibit the access of water to the canister.

The second level in the containment system hierarchy lists four general ways the containment system can fail. These are the loss of 


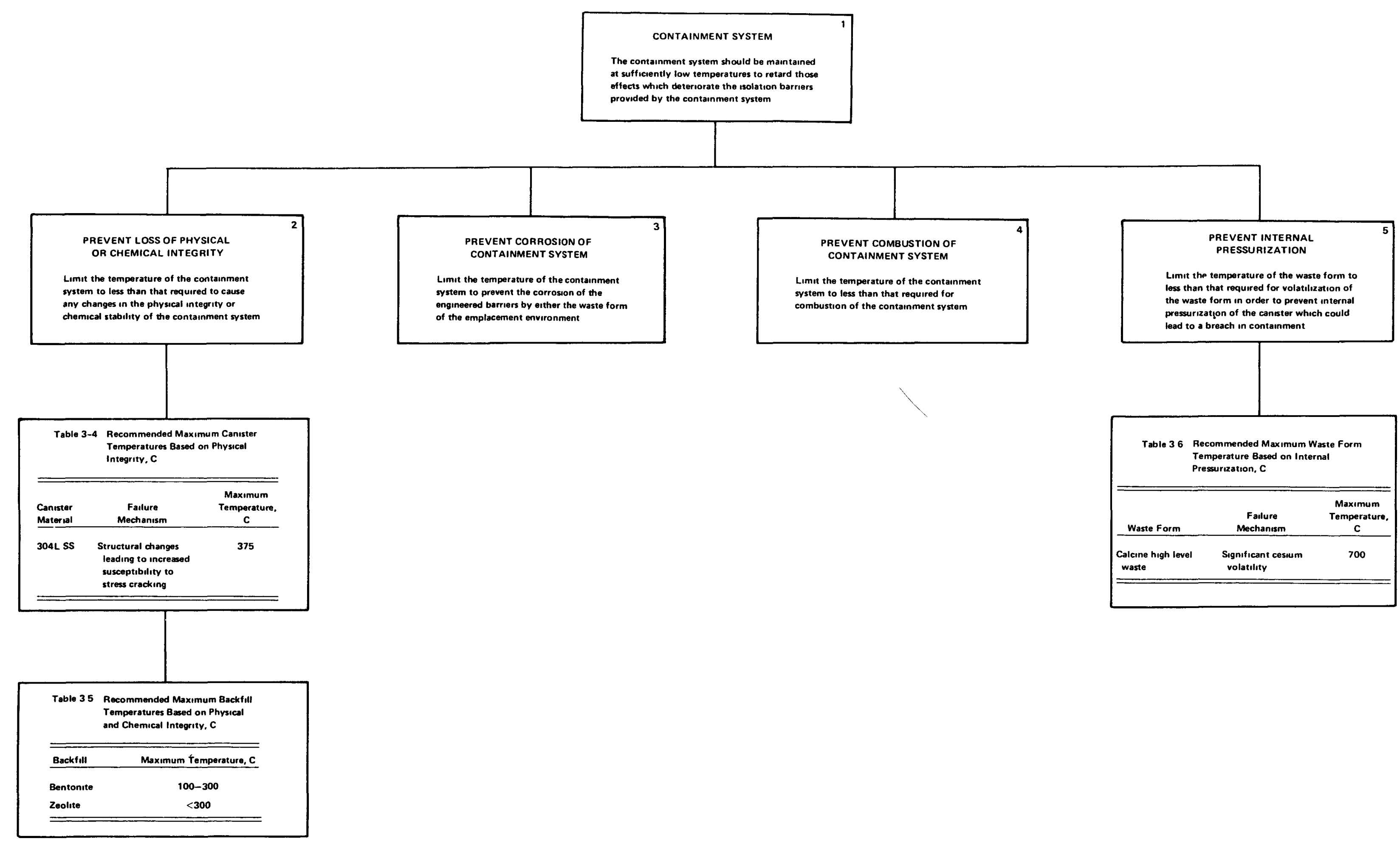

FIGURE 3-11. HIERARCHY OF CONTAINMENT SYSTEM LIMITS 
physical or chemical integrity, corrosion, combustion, and internal pressurization.

Item 2 of Figure $3-11$, loss of physical or chemical integrity is a rather broad failure mechanism. Generally stated, the containment system temperatures must be limited to avoid undesirable chemical or physical reactions in the containment system, between the waste form system and the containment system, or between the containment system and the emplacement environment. Tables 3-4 and 3-5 (Figure 3-11) give some possible failure mechanisms in this class for the canister and the backfill.

At elevated temperatures it is possible for the canister to lose its physical integrity. When 304L stainless steel is heated to temperatures greater than $375 \mathrm{C}$, structural changes occur which lead to an increased susceptibility in the alloy to stress cracking on subsequent exposure to water (Jenks, 1977). Because of the effect, Jenks has recommended a maximum temperature of $375 \mathrm{C}$ for $304 \mathrm{~L}$ stainless steel. It has also been suggested that, while carbon steel can probably tolerate higher temperatures than $304 \mathrm{~L}$ stainless steel, its maximum temperature also be set at 375 C (Jenks, 1977).

Swedish scientists have expressed concern that pure bentonite backfill will not retain its physical and chemical integrity in a repository environment at temperatures greater than $100 \mathrm{C}$ (Ahlstrom, 1979). Other sources, however, report that bentonite retains its properties to at least $300 \mathrm{C}$ (Miller and Wurm, 1980). The maximum allowable temperature for bentonite could, therefore, be as low as $100 \mathrm{C}$ or as high as $300 \mathrm{C}$ ( see Table 3-5 of Figure 3-11). 
Another possible backfill material is zeolite. At temperatures well below $300 \mathrm{C}$, however, zeolites tend to lose their water and, therefore, their cation exchange capability (Miller and Wurm, 1980). Based on this, a maximum temperature no higher than $300 \mathrm{C}$ is recommended for zeolites (Miller and Wurm, 1980).

Since corrosion of the containment system is such an important failure mechanism for the containment system, it is included in the containment system hierarchy as a separate entry instead of being included in the physical and chemical stability entry. Corrosion of the containment system can be initiated by either the waste form or the elements of the emplacement environment. The maximum allowable temperature for the containment system based on corrosion failure will vary with the waste form, the containment material, and the medium.

High-temperature corrosion by the waste on the canister depends on the materials involved. For a calcine waste form in a steel canister, not much is known. Cesium oxide corrosion of $304 \mathrm{~L}$ stainless steel indicates that intergranular corrosion occurs in a linear fashion with time (Westinghouse, 1983). Maximum temperatures of $800 \mathrm{C}$ and $100 \mathrm{C}$ have been recommended for 1020 carbon steel and 304L stainless steel, respectively (Westinghouse, 1983).

Corrosion of the canister by ground water is also important. Ground water contacting the canister will have high ionic strength, low $\mathrm{pH}$, and will probably contain very low starting concentrations of the container materials (Ad Hoc Panel of Earth Scientists, 1978). These conditions impose a very severe corrosive environment on the canister. And, as the surface temperature of the canister increases so will the corrosion rate of the canister. 
Data for the influence of temperature on the rate of corrosion for conditions of interest, however, are lacking. Rough estimates of how corrosion rates are influenced by temperature can be seen in Figures 3-12 and 3-13. Braithwaite and Molecke (1979) have shown that the alloys Hastelloy C-276, Inconel 625 and 600, Incoloy 825, and several titanium-base alloys are resistant to corrosion by oxygen-free brine solutions to $250 \mathrm{C}$. A corrosion rate of $0.7 \mathrm{mils} /$ year for 304L SS exposed to deoxygenated brine at $250 \mathrm{C}$ has been measured. Under the same conditions, however, low carbon steel has shown a corrosion rate of $68 \mathrm{mils} /$ year, which is considered unacceptably high in brine (Rockwell International, 1979).

The third possible canister breach mechanism is combustion. In general, the temperatures of the containment system should be kept below the temperature required for combustion to prevent the possible dispersal of the waste. The temperature at which combustion w111 occur Is a function of the surface area and the material properties of the containment system.

The last possible canister breach mechanism is the rupture of the canister by internal pressure. This failure mechanism is directly related to the encapsulated waste form. Volatilization of the waste form must be prevented so that overpressurization of the containment system, especially the canister, does not occur. Calcine high-level waste is a potential instigator of this failure mechanism, as it experiences significant cesium volatility at temperatures greater than 750 C (Jenks, 1977) (see Table 3-6 of Figure 3-11).

As can be seen in Figures $3-6$ and $3-11$, some of the failure mechanisms identified are lacking thermal-thermomechanical limits. 


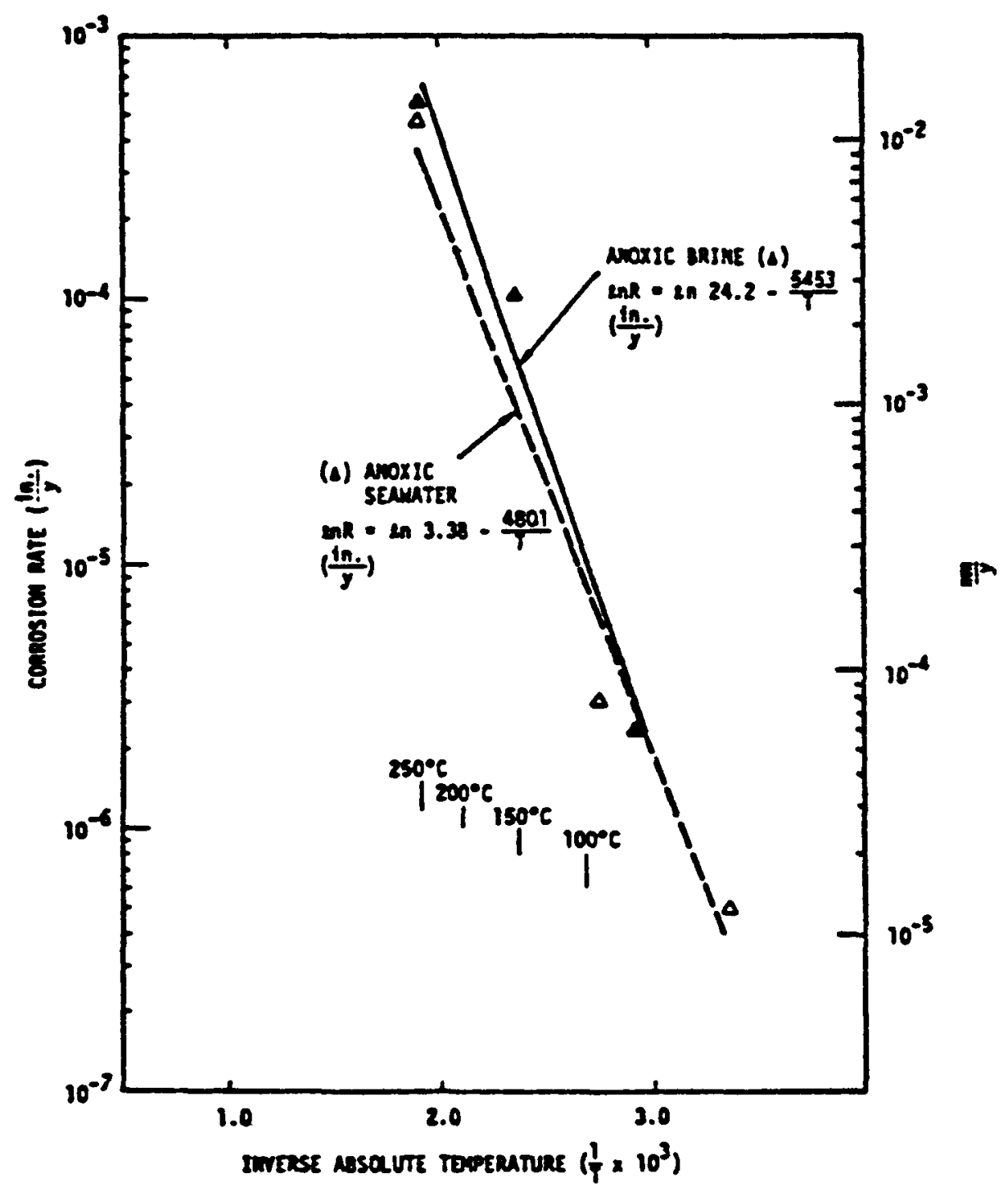

FIGURE 3-12. THE ESTIMATED TEMPERATURE DEPENDENCY OF NICKEL ALLOY CORROSION IN OXIC BRINE AND ANOXIC SEAWATER (WADDELL ET AL, 1981) 


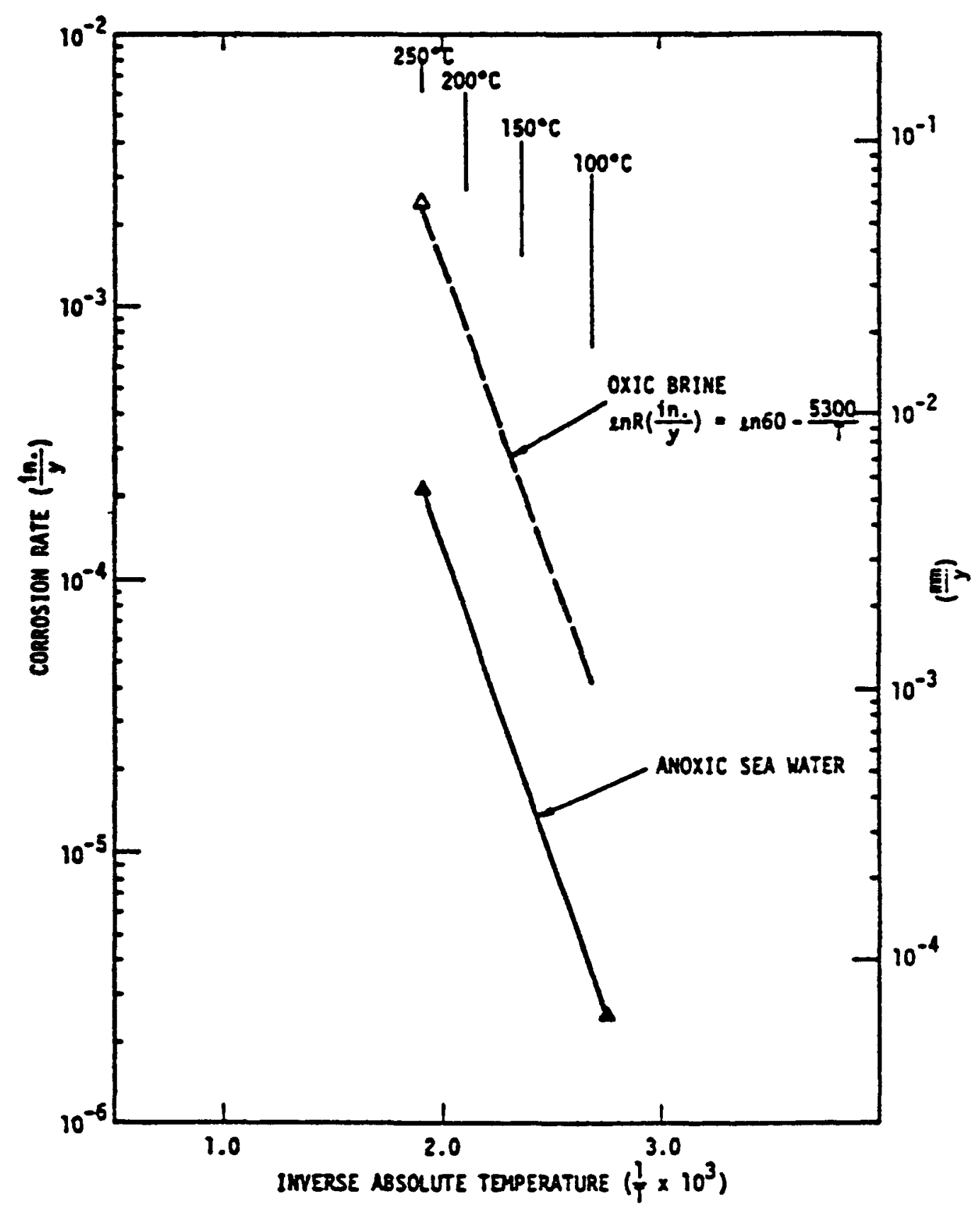

FIGURE 3-13. TEMPERATURE DEPENDENCY OF COMMERCIALLY PURE TITANIUM CORROSION IN OXIC BRINE AND ANOXIC SEAWATER (WESTINGHOUSE, 1983) 
Since these limits are not available in the literature, work should be undertaken to determine them. Only when this is done will the thermal criteria hierarchy be applicable to all possible repository designs.

\subsubsection{Repository System}

The repository system has been defined as the conduit which allows the waste packages to be emplaced deep within the geologic formation. The functions of this system are to provide for (1) the operational safety and comfort of onsite personnel, (2) emplacing the wastes, and (3) retrieving the wastes should it become necessary or desirable. The heat generated by the encapsulated wastes can endanger the ability of the repository to perform its functions. Repository temperatures should, therfore, be maintained at sufficiently low levels to retard those effects which are detrimental to the repository functions.

The repository system can be further subdivided into the waste handling system and the sealing system. The physical components of the waste handling system are the shafts and the rooms and pillars. The sealing system is an engineered system, consisting of the shaft and borehole seals and the backfills, designed to maintain waste isolation after repository closure.

\subsubsection{Waste Handling System}

Figure 3-14 shows a hierarchy representation of the waste handling system. (The following discussion will refer to Figure 3-14.) The functions of this system are to provide access from the surface to the repository by means of shafts, to provide access to the emplacement 


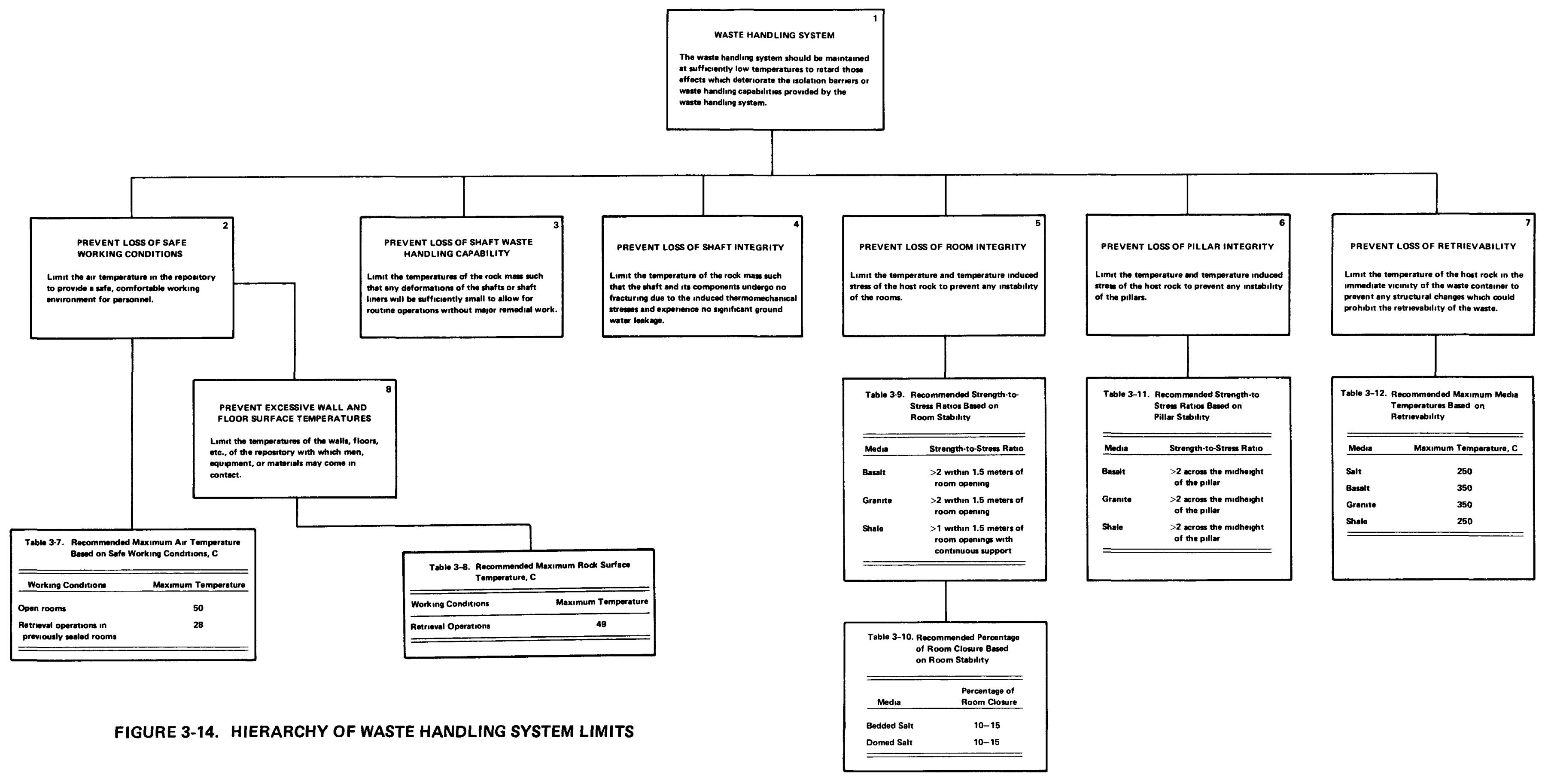


rooms, to provide a safe, comfortable working environment for personnel and equipment, and to provide for the retrieval of the wastes. The waste handing system dominates the repository system during the operational phase of the repository.

As can be seen from Figure 3-14, the primary source of unsafe working conditions is excessive temperatures. Temperatures in the storage rooms are affected by the volume of rock mined and depend on the heat capacity and density of the host rock. The radiative heat transfer properties of storage room surfaces also influence the room temperatures. To assure a safe working environment, in terms of both air and surface temperatures, a maximum working temperature of $50 \mathrm{C}$ has been recommended for retrieval operations in open rooms (Rockwell International, 1979). For retrieval operations in rooms from which backfill has been removed, a temperature of $28 \mathrm{C}$ is recommended (Rockwel1 International, 1979) (see Table 3-7 of Figure 3-14).

The surface temperatures that the personnel, equipment, and materials come in contact with are also important, in their own right, as they can lead to elevated air temperatures. Figure 3-15 shows how the floor temperature of a repository in salt for high-level waste in stainless steel canisters at a $155 \mathrm{~kW} /$ acre thermal loading will vary over time. The initial temperature at the mine level is $93 \mathrm{~F}$. Both the air temperature and the wall and floor temperatures can be reduced with mine ventilation (see Figure 3-15). A maximum rock temperature of $49 \mathrm{C}$ has been suggested for the safe operation of retrieval equipment by the Mine Design Working Group of Sandia National Laboratories in the draft activity work package on blast cooling and continuous cooling (see Table 3-8 of Figure 3-14). The capability of a repository to 


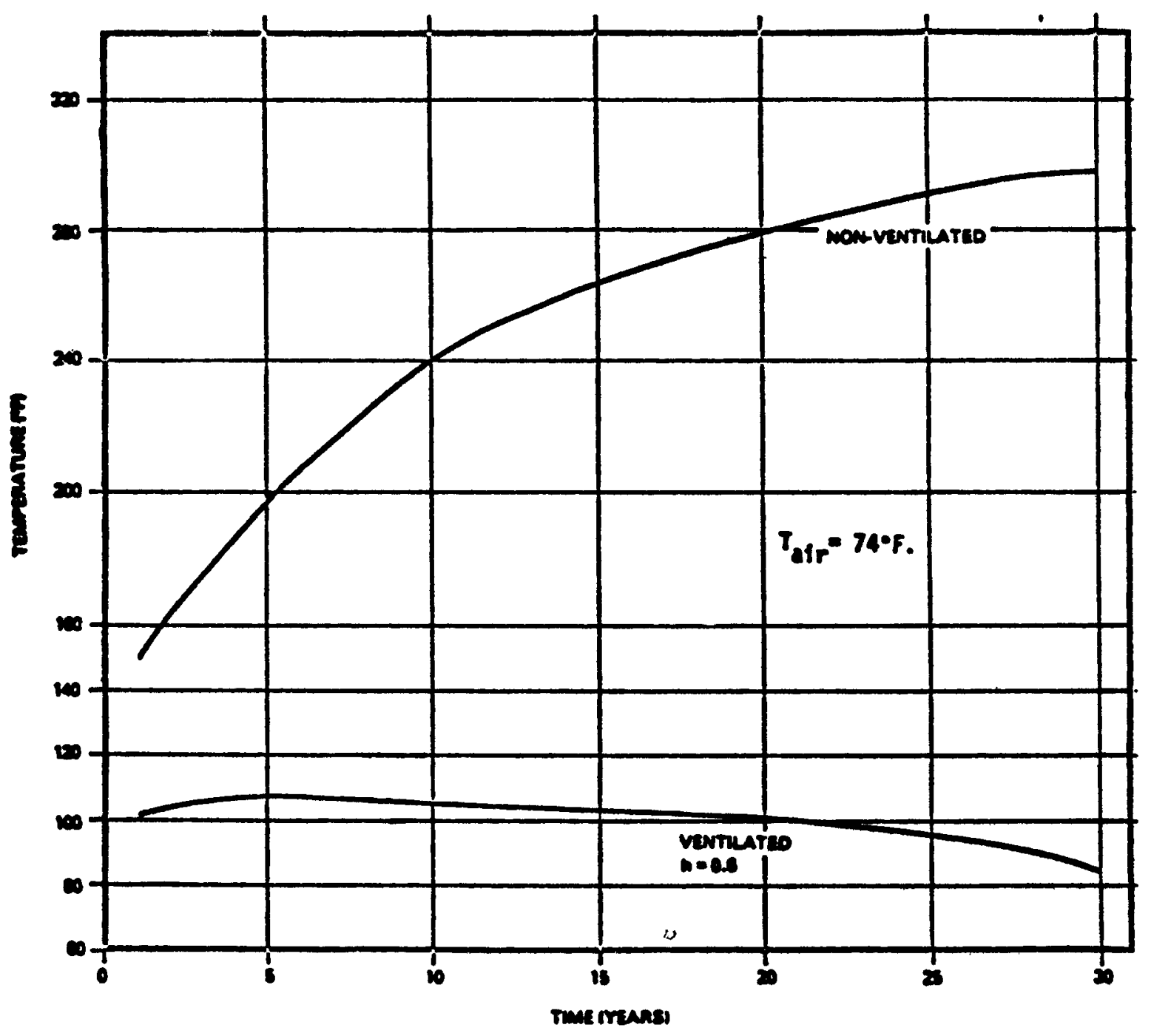

FIGURE 3-15. COMPARISON OF PEAK FLOOR TEMPERATURES (RUSSELL, 1977) 
handle the wastes can be seriously jeopardized if the shafts from the surface to the underground emplacement area suffer damage as a result of the thermal energy release of the wastes. For all the candidate media, it has been recommended that any deformations of the shafts and shaft liners be sufficiently small so that routine shaft operations are not Impeded (NWTS Working Group on Far-Field Performance Constraints in the draft on repository performance constraints in the far-field domain). Potentially, shaft deformations will be much greater for salt repositories than for other media.

In terms of waste isolation, the loss of shaft integrity is a serious concern. Should water leakage occur, a primary pathway for radionuclides to the surface would be created. To prevent this failure mechanism it has been recommended that, in any rock type, the shaft and its components undergo no fracturing due to the thermomechanical stresses induced in the repository and have no significant water leakage (NWTS Working Group on Far-Field Performance Constraints). The prevention of significant water leakage through the shaft is an important consideration.

Another critical element in the waste handling system is the stability of the rooms. The stability of rooms in hard, brittle rocks, such as granite or basalt, is felt to be assured if the stresses in the rock around the room opening are limited so that even the possibility of minor instabilities is eliminated (Dames and Moore, 1978). In shale, a weaker, more ductile rock, it may not be possible to construct rooms with the required degree of stability without continuous engineered support. Provided the effect of temperature on rock mass strength and stress-strain behavior is taken into account, the 
strength-to-stress ratio should be, at the minimum, 2 within 1.5 meters of the room opening, whereas for shale the minimum strength-to-stress ratio is 1 within 1.5 meters of the room opening with continuous engineered support (Dames and Moore, 1978).

The measure of room stability in salt is the percentage of room closure at the end of the retrievability period. This parameter is used, instead of the strength-to-stress ratio, since salt tends to creep at elevated temperatures. As with granite, basalt, and shale, this performance measure is directly related to the stress and minegeometry parameters of the repository. A maximum closure of 10 to 15 percent is recommended for bedded and domed salt in order to maintain access to the rooms throughout the retrievability period (Ad Hoc Panel of Earth Scientists). Closure constraints, however, neglect the fact that salt can undergo brittle failure.

Related to the room stability is the integrity of the associated pillars. Based on past experience at zero thermal loading, pillar stability is considered assured if the average stress across the mid-height of the pillar is less than one-half of the uniaxial compressive strength of the pillar (Dames and Moore, 1978). Provided the effect of temperature in rock mass strength and stress-strain behavior is taken into account, the strength-to-stress ratios shown in Table 3-11 (Figure 3-14) are recommended for pillar stability. For granite, basalt, and shale a minimum strength-to-stress ratio of 2 across the mid-height of the pillar is suggested (Dames and Moore, 1978).

The last element in the waste handling hierarchy is the loss of retrlevability of the waste packages. To assure retrievability of the 
canister, extensive rock fracturing around the canister cannot be allowed. Small pieces of fractured rock could jam the canister. The maximum rock temperatures shown in Table 3-12 (Figure 3-14) are recommended to prevent this. In the case of salt, both bedded and domed, decrepitation tends to occur at temperatures greater than $250 \mathrm{C}$. For shale, $250 \mathrm{C}$ may also be reasonable. In the hard rocks, granite and basalt, 350 C may be acceptable (U.S. Department of Energy, 1979).

\subsubsection{Sealing System}

A hierarchy representation of the sealing system is shown in Figure 3-16. (The following discussion will refer to Figure 3-16.) The sealing system consists of the shaft and boreholes seals, and backfill for the rooms, corridors, and underground areas. The primary function of the sealing system is to provide for the long-term integrity of the shaft and borehole seals, and backfills with respect to ground water leakage.

There are two ways in which the sealing system can fail. These are the loss of physical integrity and the loss of hydrologic integrity. To prevent the first failure mechanism, loss of physical integrity, it is recommended that the shaft and its components undergo no adverse structural changes such as fracturing due to the elevated temperatures and the resulting thermomechanical stresses (NWTS Working Group on Far-Field Performance Constraints in the draft repository performance constraints in the far-field domain). The second failure mechanism can be prevented by requiring sufficiently low temperatures so that adverse changes in the permeability of the shaft and borehole 


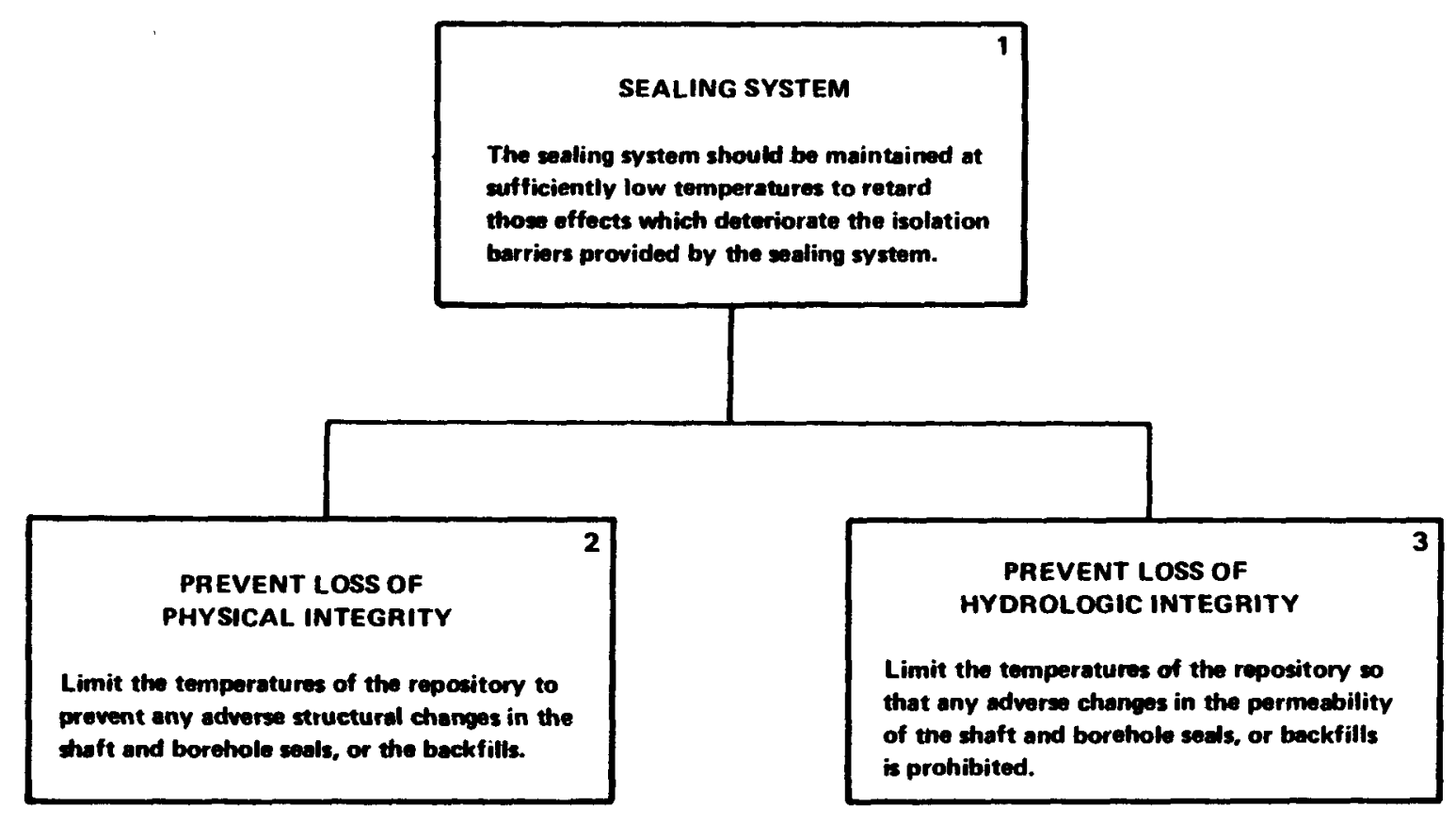

FIGURE 3-16. HIERARCHY OF SEALING SYSTEM LIMITS 
seals, and the backfills, do not occur. For basalt and bedded and domal salt, it is recommended that the permeability of the sealed boreholes and shafts be approximately the same as the aquitards in those zones where aquitards are intersected. In granite and tuff, it is recommended that the effective permeability of the sealed shaft and boreholes be approximately the same as the host rock permeability for the middle 70 percent of their length (NWTS Working Group).

It is apparent from Figures 3-14 and 3-16 that some of the failure mechanisms identified by the waste handling and sealing systems are lacking thermal-thermomechanical limits. This is due to the absence of such limits in the literature. For the thermal criteria hierarchy to realize its full potential these limits must be determined.

\subsubsection{Site System}

The site system consists of the geologic, hydrologic, and geochemical systems that provide natural isolation barriers to the migration of radioactive wastes. As a system, the site has three functions:

(1) provide a site suitable to the long-term isolation of the radioactive wastes; (2) provide a site whose physical, hydrologic, and chemical properties will act to retard the migration of radionuclides; and (3) provide for the retrieval of the wastes, should that be necessary. The heat generated by the emplaced wastes could endanger the ability of the site system to provide natural isolation barriers to radionuclide migration. The site system should therefore be maintained at sufficiently low temperatures to retard those effects which deteriorate the isolation barriers of the site system. 
The site system can be further divided into three lower order systems to facilitate the determination of maximum temperatures or temperature-related limits. These three systems are the geologic system, the hydrologic system, and the geochemical system. The geologic system is composed of any acceptable igneous, sedimentary, or metamorphic formation, and its surrounding stratigraphy into which the radioactive waste is emplaced. The hydrologic system is defined as any soil, rock unit, or zone which has a distinct influence on the storage or movement of ground water by virtue of its porosity or permeability. The geochemical system consists of any interaction between the waste, rock, or ground water within the geologic formation. It is the geochemical system which binds the geologic and hydrologic systems toge ther.

\subsubsection{Geologic System}

An ordered representation of the geologic system is shown in Figure 3-17. (The following discussion will refer to Figure 3-17.) Its functions include providing an environment suitable for the longterm isolation of radioactive wastes, providing an environment which will retard the migration of radionuclides, and providing for the retrievability of the wastes. To accomplish its functions the geologic system should be maintained at sufficiently low temperatures to retard those effects which are detrimental to its functions. The second level in the geologic system hierarchy lists the ways in which the geologic system could fall to perform its functions.

The first means by which-the geologic system can fail is to lose its physical integrity. Excavation of a repository and the release of 


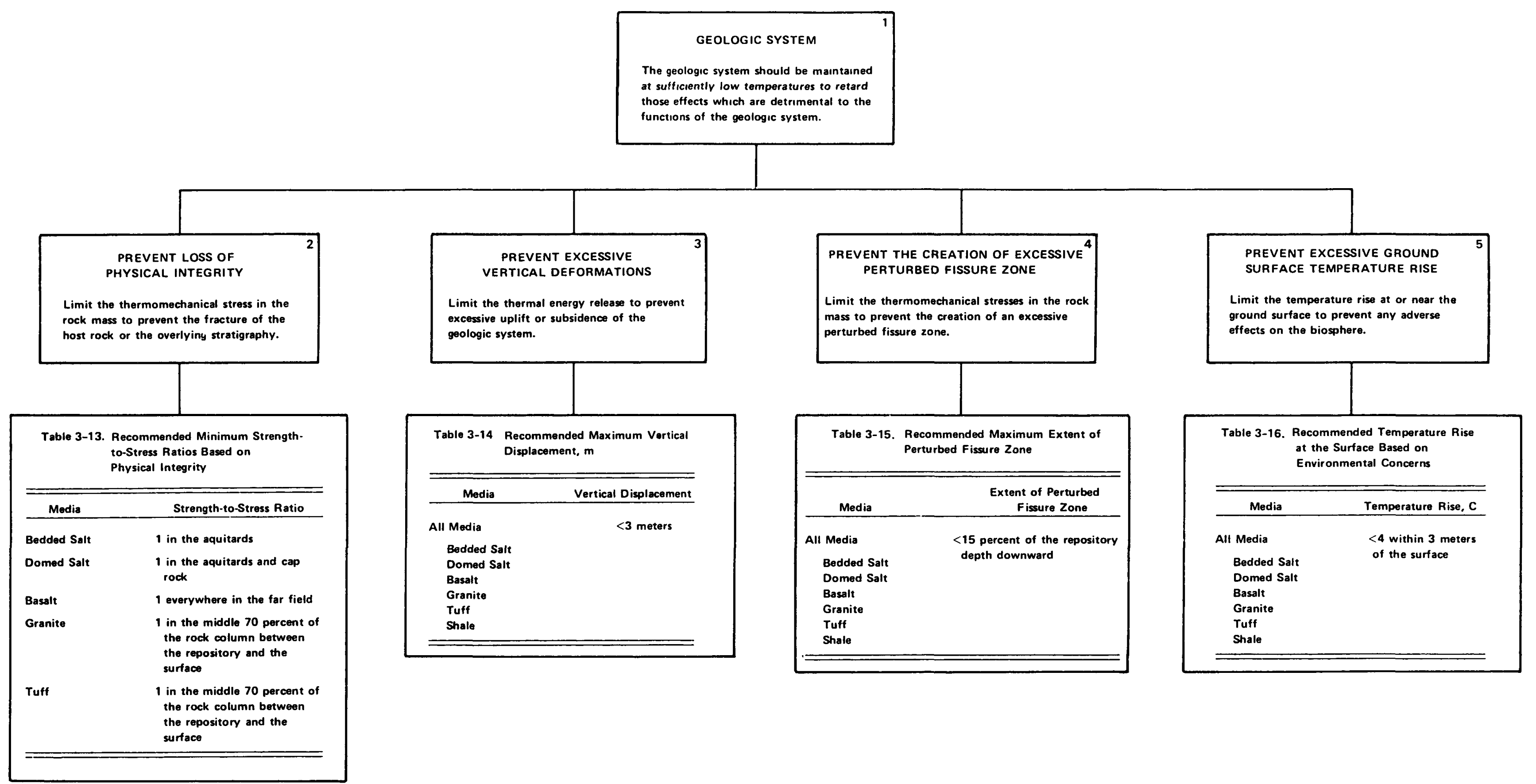

FIGURE 3-17. HIERARCHY OF GEOLOGIC SYSTEM LIMITS 
O 0 
thermal energy by the emplaced wastes causes a change in the stresses in the rock mass. These are generally compressive in nature through most of the rock mass, therefore leading to a potential for shear failure in those regions where the rock mass strength is exceeded. The potential for shear failure is greatest near the repository and diminishes with distance. Minimum strength-to-stress ratios, shown in Table 3-13 (Figure 3-17), are recommended to prevent shear failure in the rock mass.

For basalt, the minimum strength-to-stress ratio everywhere in the far-field region should be greater than one (NWTS Working Group on FarField Performance Constraints in its draft on repository performance constraints in the far-field domain). In granite and tuff the minimum strength-to-stress ratio should remain greater than one in the middle 70 percent of the rock column lying between the repository horizon and the ground surface (NWTS Working Group). The analysis of fracturing is more complex for salt than for the other media since the nonlinear plastic creep of salt and other sedimentary strata must also be taken into account. A minimum strength-to-stress ratio of one is recommended for the aquitards and the caprock of bedded and domed salt, respectively (NWTS Working Group).

As the thermal energy of the radioactive waste is released, the rock mass will vertically deform upward because of thermal expansion. As this thermal energy is exhausted, the rock mass will subside. While surface ground displacements will not form a breach of the natural geologic barrier, it may be of sufficient magnitude to be environmentally unacceptable. Extensive vertical deformation could cause changes in runoff patterns or distress surface structures. The maximum vertical 
displacement for any medium is recommended to be less than 3 meters (see Table 3-14 of Figure 3-17) (NWTS Working Group). Due to room closure, after repository decommissioning, the maximum subsidence will probably occur earlier than maximum uplift.

A failure mechanism directly related to vertical displacement and fracturing is the creation of a perturbed fissure zone (NWTS Working Group). When the rock mass bulges upwards due to thermal expansion, horizontal tensile stresses may be created in the upper portion of the rock mass. Since most geologic materials have very low tensile strengths, there is a potential for creating new vertical fractures or for opening existing ones. For all rock types, it is recommended that the perturbed fissure zone should not extend downward from the surface more than 15 percent of the repository depth (see Table 3-15 of Figure 3-17) (NWTS Working Group).

The last mode of failure for the geologic system is excessive ground surface temperature rise. While this will not directly alter the performance of the geologic system, it may be environmentally unacceptable. A maximum temperature rise of less than $4 \mathrm{C}$ within three meters of the surface is recommended (NWTS Working Group). A depth of 3 meters was selected to include most, but not all, biological systems such as roots, burrowing animals, and insects.

\subsubsection{Hydrologic System}

A representation of the hydrologic system as a hierarchy is shown 1n Figure 3-18. (The following discussion will refer to Figure 3-18.) The basic functions of the hydrologic system are to provide an environment which will prevent or retard the migration of radionuclides and to 


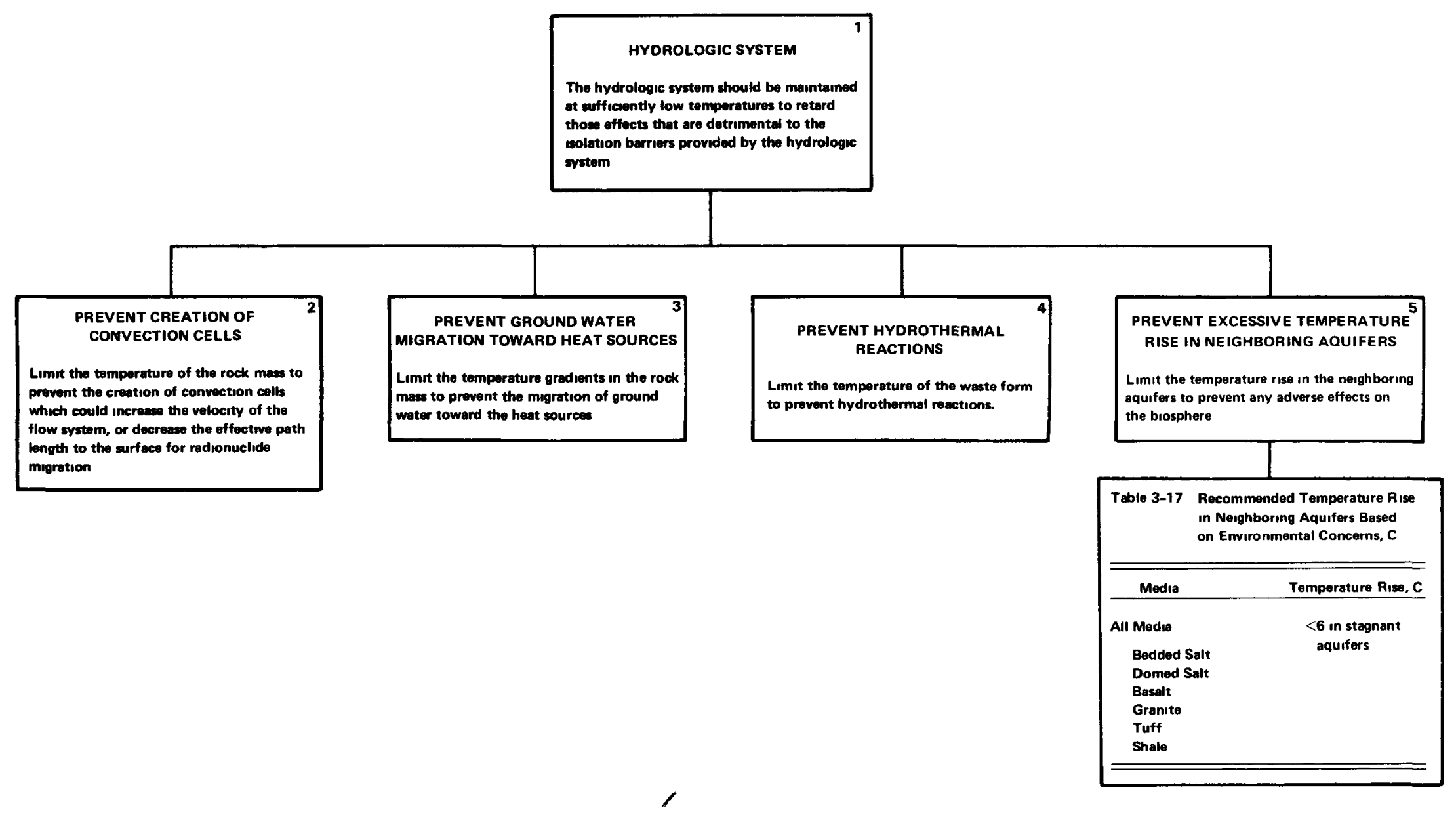


prevent the introduction of ground water into the repository. The hydrologic system should, therefore, be maintained at sufficiently low temperatures to retard those effects which deterlorate its effectiveness as an isolation barrier.

The creation of convection cells is a primary means of fallure for the hydrologic system. The thermal energy released by the emplaced wastes could cause the creation of convection cells, giving rise to an increase in the flow velocity and/or the development of a vertical component to the flow (NWTS Working Group on Far-Field Performance Constraints in its draft on repository performance constraints in the far-field domain). For repositorles in salt there is the additional concern that the convection cells might cause the dissolution of the formation. It is therefore recommended that the transit time for ground water to travel from the repository to the ground surface as a consequence of thermal convective forces be greater than 1,000 years for basalt, granite, and tuff (NWTS Working Group). For repositories in bedded or domed salt, it is recommended that no significant therma1ly induced convection cells contact the salt formation (NWTS Working Group).

The migration of ground water towards a heat source is an important fallure mechanism in bedded salt. Bedded salt usually contains a small number of brine inclusions. All fluid brine-filled cavities have been shown to migrate up any existing temperature gradients. This migration of brine results from an increase in the solubility of the salt with increased temperature and from thermal effects within the brine. The rate of brine migration will vary with temperature, as seen 
in Figure 3-19. The quantity of brine and its arrival rate are important parameters for bedded salt.

Dissolution of the waste form with the subsequent release of radionuclides can occur if the waste form comes in contact with ground water at the high temperature and pressure conditions of a geologic repository. Most waste forms are susceptible to hydrothermal reactions at temperatures above $100 \mathrm{C}$ (Cohen et al, 1977). The extent of any waste form dissolution will be significantly influenced by the chemical composition of the ground water, particularly its $\mathrm{pH}$ and the oxidizing or reducing capacity of the repository environment. In spent fuel, the most leachable elements under oxidizing conditions appear to be cesium, rubidium, molybdenum, and strontium (Rockwell International, 1979). For borosilicate glass, the most leachable elements, under oxidizing conditions, appear to be sodium, silicon, molybdenum, uranium, and cesium (Rockwe11 International, 1979).

While excessive temperature increases in neighboring aquifers will not cause a breach in the geologic isolation barriers they may be environmentally unacceptable. Temperature rises in aquifers could result in higher temperature water being carried outside the repository area. This in turn could cause adverse effects in the biosphere. A maximum temperature rise of less than $6 \mathrm{C}$ has been recommended for stagnant aquifers (Ahlstrom, 1979). For aquifers in areas of low heat flux, a small flow rate would significantly reduce the temperature rise. 


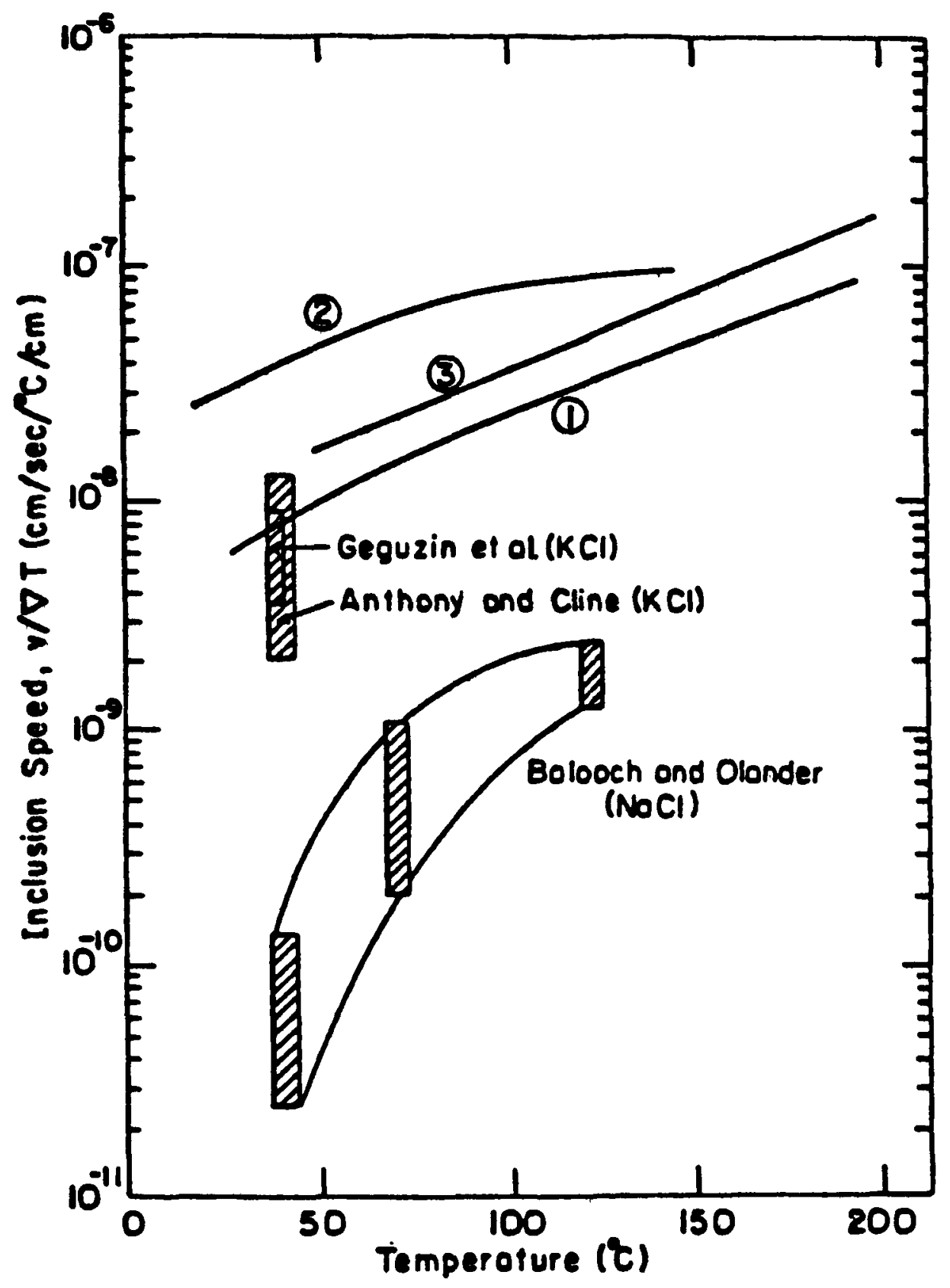

FIGURE 3-19. MIGRATION SPEEDS PER UNIT TEMPERATURE GRADIENT OF ALL-LIQUID INCLUSIONS (OLANDER ET AL, 1980) 


\subsubsection{Geochemical System}

The last subsystem in the site system is the geochemical system. A representation of the geochemical system as a hierarchy is shown in Figure 3-20. (The following discussion will refer to Figure 3-20.) The primary function of the geochemical system is to maintain the geochemical stability of the rock mass in which the repository is located. The geochemical system should, therefore, be maintained at sufficiently low temperatures to retard those effects which are detrimental to its effectiveness as an isolation barrier.

Elevated temperatures can lead to a number of chemical effects in the rock mass. Most of these are detrimental to the geochemical system stability. Minerals may become unstable and reactions may occur which reduce the radionuclide retention capability of the formation.

The primary thermochemical concern for a repository in salt is the dissolution of the salt formation. As the temperature increases, so does the solubility of salt. Kaufman (1960) has shown that the mass of $\mathrm{NaCl}$ in a saturated solution increases by approximately 6 percent as the temperature increases from $30 \mathrm{C}$ to $100 \mathrm{C}$. A possible beneficial effect of the variation of salt solubility with temperature is the potential for plugging fractures and ground water pathways downstream from the repository when the ground water cools and precipitates some of the salt from solution.

Most of the primary and secondary minerals which form granitic rocks appear to be stable at the pressures and temperatures expected in the rock mass. One reaction, however, which does take place at low temperatures and pressures is dehydration. Most of the common 


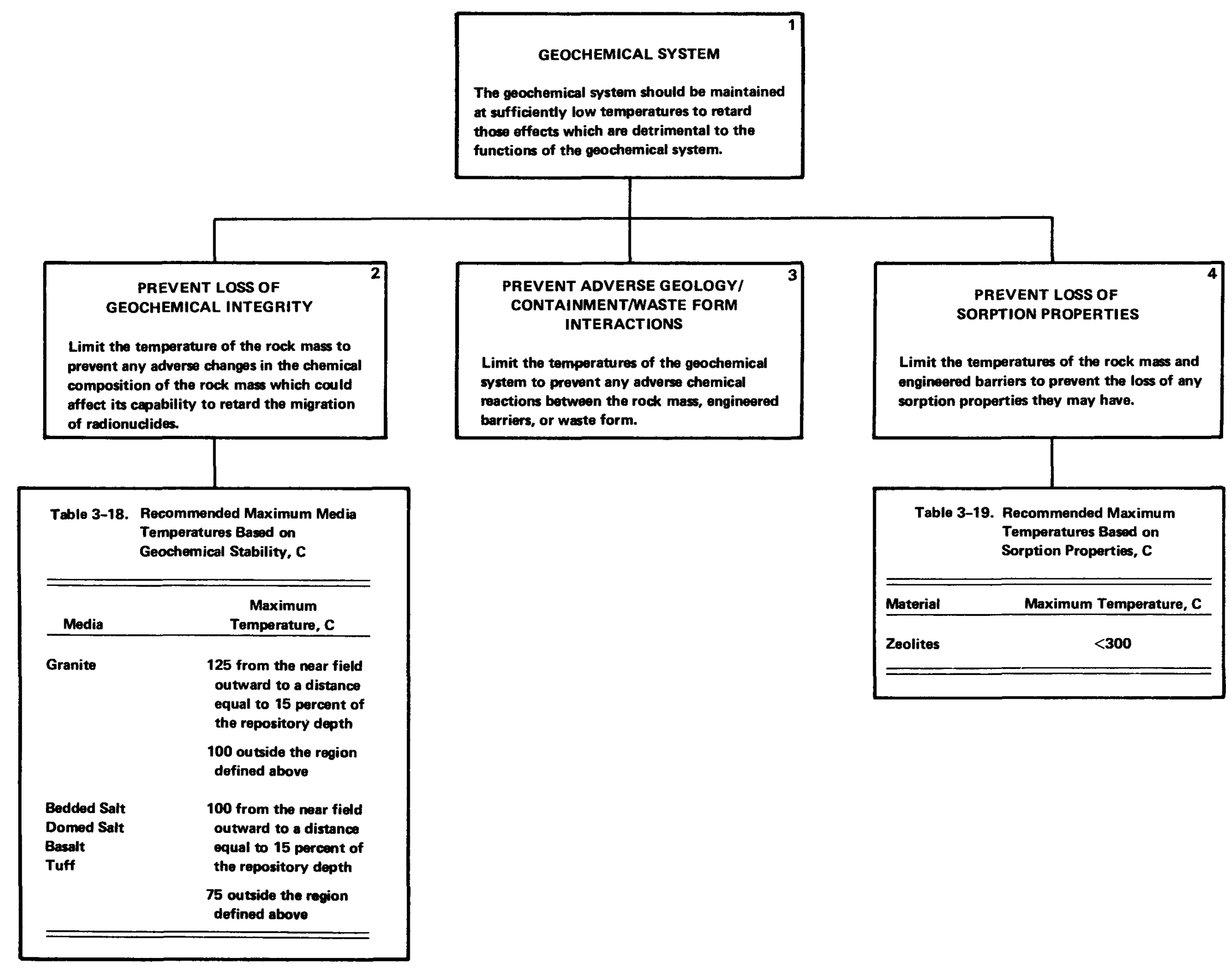


rock-forming minerals are either nonhydrous or have tightly bonded water and therefore are stable in the expected conditions. The micas are the only mineral family which can become unstable below $500 \mathrm{C}$ and low pressures. Some micas may become unstable at temperatures as low as $350 \mathrm{C}$ (NWTS Working Group on Far-Field Performance Constraints in the draft on repository performance constraints in the far-field domain). Clay minerals, which occur widely in sedimentary sequences as clay seams in salt strata and as secondary minerals on igneous rocks, can undergo dehydration and other changes at temperatures as low as 100 to $200 \mathrm{C}$ (NWTS Working Group).

A maximum temperature of $125 \mathrm{C}$ for granite and $100 \mathrm{C}$ for the other rock types is recommended for the region which extends from the repository near field outward to a distance equal to 15 percent of the repository depth (NWTS Working Group). Anywhere outside of the region defined above, a maximum temperature of $100 \mathrm{C}$ for granite and $75 \mathrm{C}$ for the other rock types is recommended (NWTS Working Group).

Compatibility between the geology and the waste package system is also an important consideration in the geochemical system. The temperatures in the geochemical system should be kept at sufficiently low values to prevent any adverse chemical interactions between the rock mass, engineered barriers, and the waste form. Preliminary experiments show that waste-rock interactions, in the presence of ground water and under moderate temperature and pressure conditions, will be rapid and extensive if the container is breached (McCarthy et a1, 1978). Ground water would be expected to transport species to and from the waste form and the host rock. This would produce a zone around the waste canister in which new minerals could develop (McCarthy et al, 1978). 
There is also the potential for beneficial chemical reactions occurring in the geochemical system. The adsorption of migrating radionuclides on the overpack, backfill, host rock, secondary minerals, or sediments is one such favorable reaction. The loss of these sorption properties should be prevented.

Materials selected for their sorption properties should be thermally stable, have good heat-conducting propertles, and have low permeability to ground water in the repository environment. Zeolites, such as chabazite and clinoptilolite, are examples of inorganic sorption materials. At temperatures well below $300 \mathrm{C}$, however, zeolites tend to lose their water and, therefore, their sorption properties (Miller and Wurm, 1980).

From Figures $3-17,3-18$, and $3-20$ it can be seen that some of the failure mechanisms are lacking thermal-thermomechanical limits. These gaps in the thermal limits prevent the thermal criteria hierarchy from realizing its full potential. Since these limits could not be found in the literature, work should be undertaken to determine them. 
4 APPLICATION AND IMPACTS OF THE THERMAL CRITERIA HIERARCHY

There are several possible uses for the thermal criteria hierarchy developed in Chapter 3. Some of these potential uses are to determine the thermal-thermomechanical limits applicable to a given repository design or to determine if the thermal performance of a given repository design is acceptable, and to evaluate the impact on a given repository design of a change in the thermal limits or to evaluate the impact on the thermal 1imits of a change in a given repository design. Section 4.1 demonstrates the selection of temperature limits for an example waste type and form, canister, backfill, and medium. Then an example repository design for the given waste package and medium is evaluated to determine 1 ts thermal performance. Section 4.2 briefly discusses the impacts of various repository design alternatives. As an example of an alternative, the waste type in Section $4.1,10$-year-old BWR, is cooled an additional 90 years prior to permanent disposal. The possible impacts associated with this design variation are briefly described.

\subsection{APPLICATION OF THE THERMAL CRITERIA HIERARCHY}

Over the years, several design studies have been prepared for the disposal of nuclear waste in geologic repositories. Each of these studies developed a set of thermal limits by which to evaluate their designs. The thermal constraints chosen for spent fuel in salt by three of these studies are listed in Table 4-1. 
Table 4-1. Comparison of Thermal - Thermomechanical Limits Chosen by the Management of Commercially Generated Radioactive Wastes

(U.S. Department of Energy, 1980), the Westinghouse Engineered Waste Package Design Studies (Westinghouse, 1983), and the

Areal Thermal Loading Recommendations for Nuclear Waste

Repositories in Salt (Russel1, 1977)

\begin{tabular}{|c|c|c|c|}
\hline Constraints & $\begin{array}{l}\text { Management of Commercially } \\
\text { Generated Radioactive } \\
\text { Waste (U.S. Department } \\
\text { of Energy, 1980) }\end{array}$ & $\begin{array}{l}\text { Westinghouse Engineered } \\
\text { Waste Package Design } \\
\text { Studies (Westinghouse, } \\
1983 \text { ) }\end{array}$ & $\begin{array}{l}\text { Areal Thermal Loading } \\
\text { Recommendations for } \\
\text { Nuclear Waste } \\
\text { Repositories in Salt } \\
\text { (Russel1, 1977) }\end{array}$ \\
\hline $\begin{array}{l}\text { Maximum Spent Fuel } \\
\text { Temperature, } C\end{array}$ & 300 & $\begin{array}{l}375 \text { (during containment) } \\
100 \text { (after containment) }\end{array}$ & 200 \\
\hline $\begin{array}{l}\text { Maximum Canister } \\
\text { Temperature, C }\end{array}$ & $375(304 \mathrm{~L}$ SS $)$ & 250 (titanium) & 375 \\
\hline $\begin{array}{l}\text { Maximum Salt } \\
\text { Temperature, C }\end{array}$ & 250 & 250 & $260-320$ \\
\hline $\begin{array}{l}\text { Maximum Room } \\
\text { Closure }\end{array}$ & $\begin{array}{l}10-15 \% \text { of original } \\
\text { room opening }\end{array}$ & & $\begin{array}{l}10-15 \% \text { of original } \\
\text { room opening }\end{array}$ \\
\hline Maximum Uplift, m & $1.2-1.5$ & & $1.2-1.5$ \\
\hline $\begin{array}{l}\text { Maximum Temperature } \\
\text { Rise at Surface, C }\end{array}$ & 0.5 & & 0.5 \\
\hline $\begin{array}{l}\text { Maximum Temperature } \\
\text { Rise in Aquifer, C }\end{array}$ & 6.0 & & 6.0 and ALARA (a) \\
\hline
\end{tabular}

(a) ALARA = as low as reasonably achievable. 
As can be seen from Table 4-1, there is considerable variation in the thermal constraints chosen and in the values assigned to them. This variation in the choice of thermal limits reveals the need for an organized approach to the evaluation of the thermal effects on the waste disposal system that result from the thermal energy release of the waste. The hierarchy of thermal criteria, described in Chapter 3, was developed for just such a purpose.

Table 4-2 describes a possible repository configuration for disassembled BWR spent fuel in salt. A set of maximum permissible temperatures for the repository configuration shown in Table 4-2 can be obtained from the thermal criteria hierarchy developed in Chapter 3. These are 1isted in Table 4-3. In some instances, such as the corrosion limit for the canister, where temperature limits were not available for the failure mechanism, they were not included. A complete analysis of the thermal criteria hierarchy would require the determination of these missing thermal limits.

An analytical program, ARRAYF (Klett et a1, 1980, see Appendix B), was used to determine if the repository configuration shown in Table 4-2 violated any of the temperature constraints in Table 4-3. ARRAYF (Klett et al, 1980), is a computer program developed to solve the analytical equations for the conduction of heat from finite-length vertical heat sources through a semi-infintte medium with one isothermal surface. It includes up to 12 heat sources at a given distance below the isothermal surface. The isothermal plane and adjacent heat sources are added by using the method of superposition. An eight-point Gaussian quadrature technique is used to evaluate the equations. 
Table 4-2. Repository Characteristics

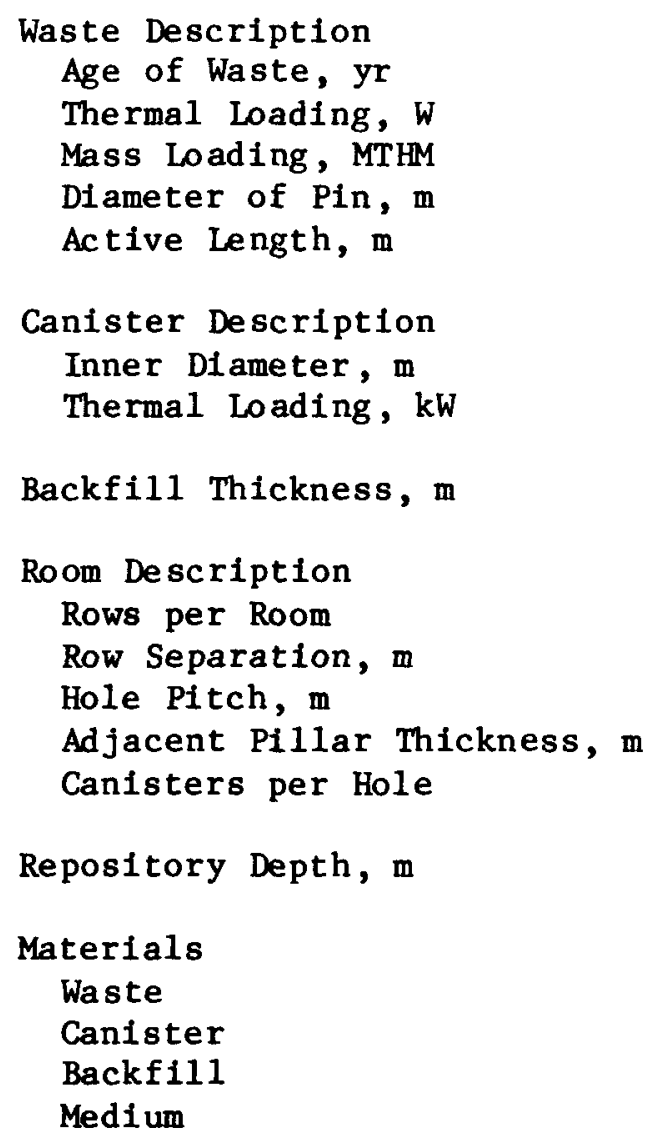

$$
\begin{aligned}
& 10.0 \\
& 2.86 \\
& 0.0029 \\
& 0.0062 \\
& 4.0
\end{aligned}
$$$$
0.232
$$$$
2.622
$$$$
0.15
$$$$
\begin{gathered}
2 \\
10.67 \\
25.65 \\
22.97 \\
1
\end{gathered}
$$

600.0

BWR Spent Fuel Pins Carbon Steel Crushed Salt Bedded Salt 
Table 4-3. A Partial Set of Restrictive Temperatures for the Repository Configuration Shown in Table 4-2(a)

Spent Fuel

during containment period

300

after containment period

Carbon Steel Canister

Salt

emplacement area

250

near field

100

far field

75

(a) Where temperature limits were not available for the failure mechanisms developed in Chapter 3, they were not included.

There are two options for the finite-length vertical heat sources available in ARRAYF: the canister option and the solid cylinder option. The canister option shown in Figure 4-1 was selected for the analysis of pins close packed in the canister, as specified by Science Applications, Inc. (1979). Since the temperature drop across the canister wall is considered to be negligible it was replaced with crushed salt backfill. The temperature is calculated at each of the 10 points shown in Figure 4-1. Table 4-4 shows the thermal conductivities, emissivities, and heat capacities assumed in the analysis. All physical property data are assumed to remain constant.

There are four possible canister arrays available in ARRAYF: a square array, a triangular array, a single-row array, and a double-row array. The double-row array was used in the analysis of the repository 


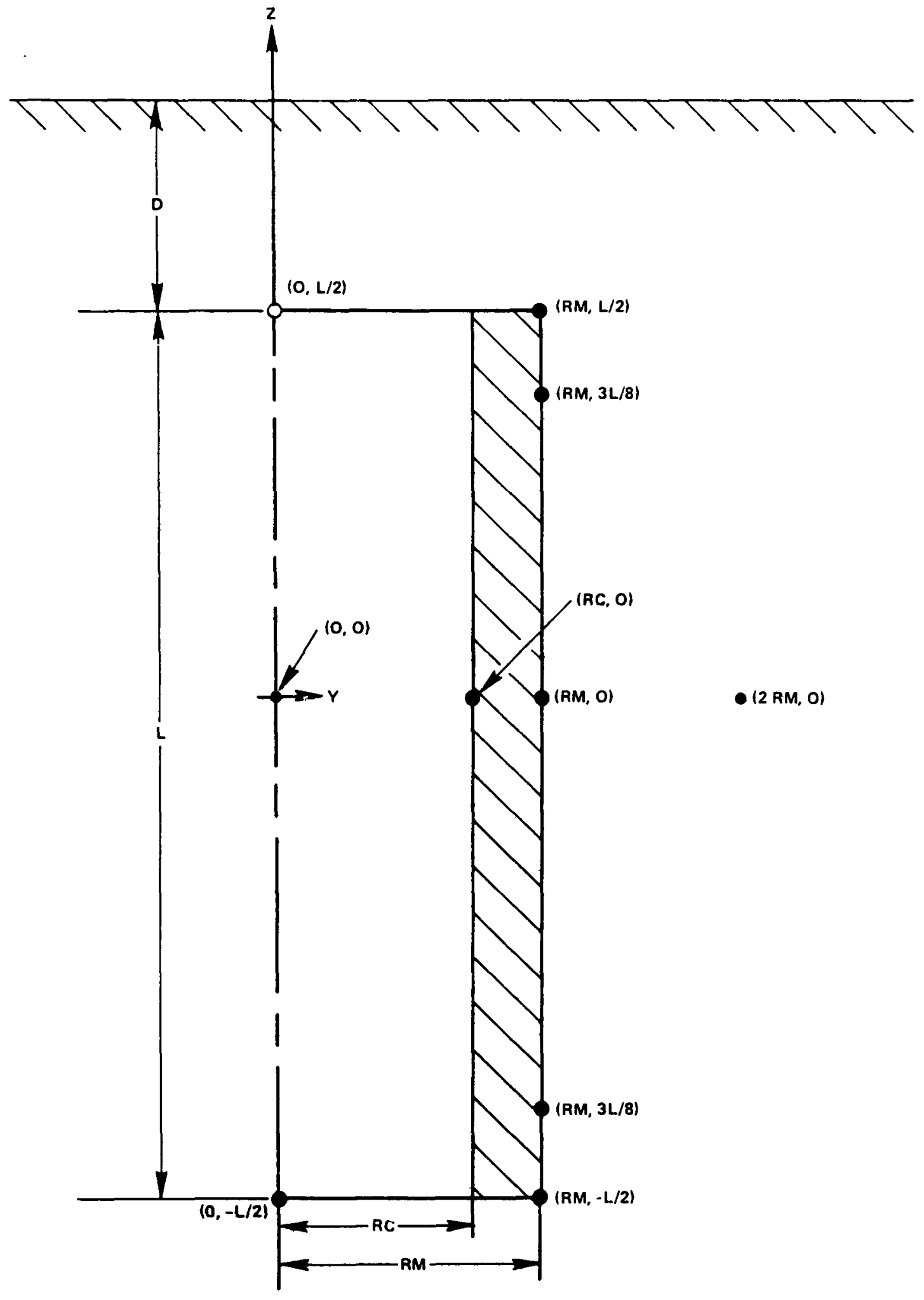

FIGURE 4-1. CANISTER CONFIGURATION USED IN ARRAYF 
configuration shown in Table 4-2. Figure 4-2 shows the arrangement of the canisters in the room.

The results of the temperature analysis of the repository configuration in Table 4-2 are shown in Figures $4-3$ and 4-4. Figure 4-3 shows the radial temperature distribution of the spent fuel canister. Figure 4-4 shows the variation of the spent fuel centerline temperature with time after emplacement. As can be seen from these figures, all the temperature limits listed in Table 4-3 are easily met. The waste containment, canister, and salt emplacement temperatures are all below their maximum values. At a distance of 0.86 meters the medium temperature is well below $75 \mathrm{C}$ and declining, thereby assuring that the nearand far-field limits will be met (Figure 4-3). The spent fuel centerline temperature 100 years after disposal is already below $100 \mathrm{C}$ and

Table 4-4. Assumed Thermal Conductivities, Emissivities, and Heat Capacities

\begin{tabular}{|c|c|c|c|}
\hline $\begin{array}{l}\text { Waste Form/Backfill/ } \\
\text { Medium }\end{array}$ & $\begin{array}{c}\text { Thermal } \\
\text { Conductivity, } \\
\mathrm{kW} / \mathrm{mC}\end{array}$ & Emissivity & $\begin{array}{l}\text { Heat Capacity, } \\
\mathrm{kJ} / \mathrm{m}^{3} \mathrm{C}\end{array}$ \\
\hline $\begin{array}{l}\text { Close-packed array of } \\
\text { BWR spent fuel pins (a) }\end{array}$ & 0.00088 & 0.6 & Neglected \\
\hline Crushed Salt Backfill(b) & 0.0003 & 0.6 & Neglected \\
\hline Salt & 0.0060 & 0.6 & 2200.0 \\
\hline
\end{tabular}

(a) A close-packed array as defined in Appendix B of Storage Room Design Parameters for the ONW.I Spent Fuel Disposal Study: Nine Case Studies in Salt (Science Applications, Inc., 1979).

(b) The emissivity assumed for salt was also assumed for the crushed salt backfill. 


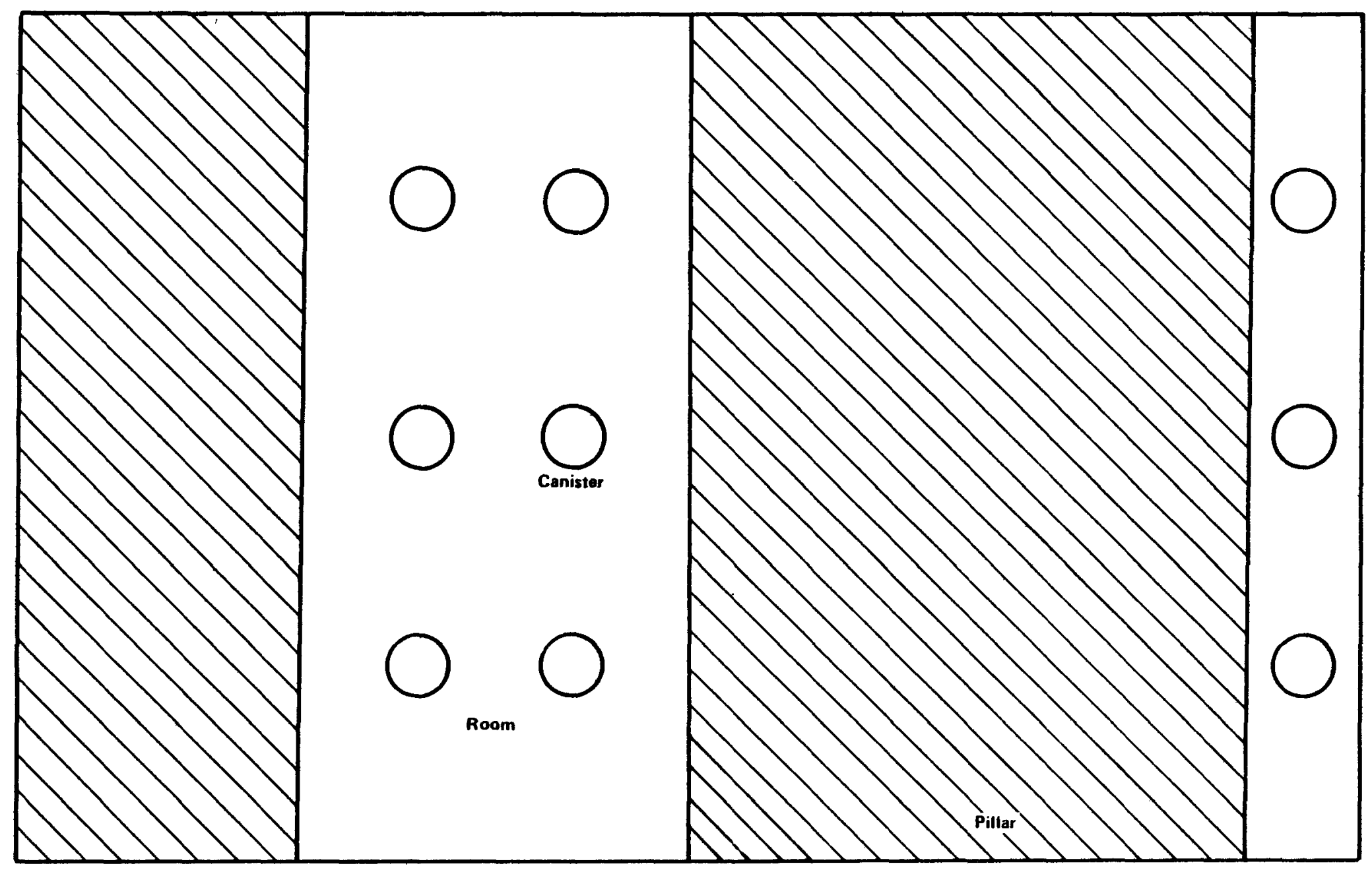

FIGURE 4-2. ROOM AND PILLAR GEOMETRY 


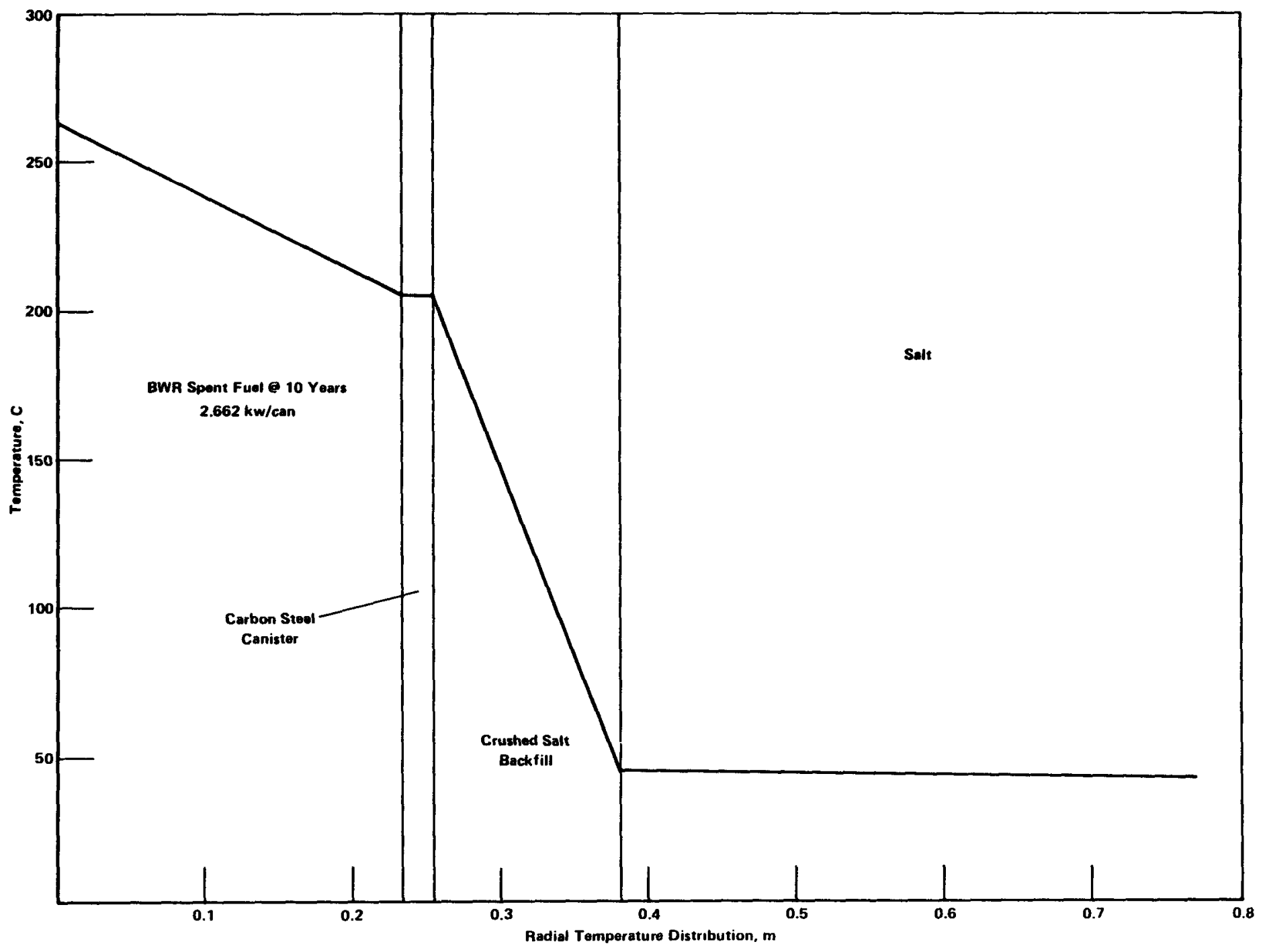

FIGURE 4-3. RADIAL TEMPERATURE DISTRIBUTION OF SPENT FUEL WASTE PACKAGE 


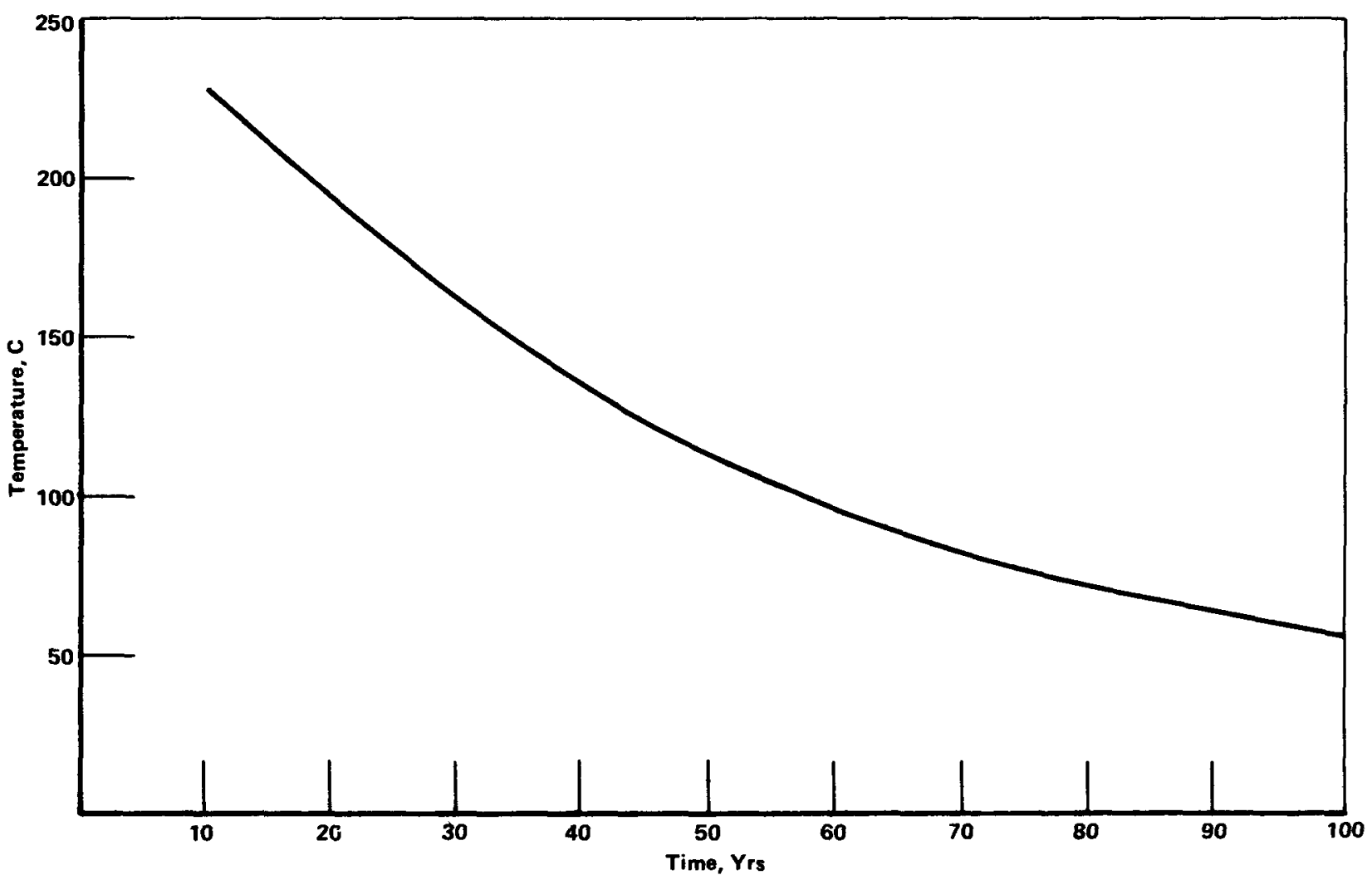

FIGURE 4-4. VARIATION OF SPENT FUEL CENTERLINE TEMPERATURE WITH TIME AFTER EMPLACEMENT 
declining, thereby assuring that at the end of the containment period the $100 \mathrm{C}$ spent fuel temperature limit will be met (Figure 4-4).

The U.S. Department of Energy (1980) specifies a maximum average thermal loading of $60 \mathrm{~kW} /$ acre based on far-field limitations, for the case of spent fuel in salt with a $15 \mathrm{~cm}$ backfill thickness. Although salt can accept higher thermal loadings based on room and pillar stability considerations, the long-term heat contribution from the plutonium in spent fuel results in unacceptable amounts of surface uplift. The additional heat contribution of plutonium does not affect room stability. In order to meet the far-field limit of $60 \mathrm{~kW} / \mathrm{acre}$, the maximum near-field density that can be achieved for spent fuel is $75 \mathrm{~kW} /$ acre (U.S. Department of Energy, 1980). At this loading, the temperature constraints on the surface and aquifers are also met.

The local thermal loading for the repository configuration in Table 4-2 is $19.7 \mathrm{~kW} /$ acre. This is well below the $60 \mathrm{~kW} /$ acre far-field limit and the $75 \mathrm{~kW} /$ acre near-field limit. Since the number of canisters or their size does not affect the far field, it is reasonable to assume that at $19.7 \mathrm{~kW} /$ acre the far-field thermomechanical limits in Chapter 3 are satisfied.

Room and pillar stability, however, is also dependent on the extraction ratio. For the calculations in this chapter the repository configuration described in a draft on interim reference repository conditions for salt was used as a starting point. The row separation and hole pitch dimensions were then varied while the pillar width remained constant. This leads to extraction ratios for the lower emplacement densities, such as that of the example, which exceed the recommended 25 percent limit for salt. The temperatures, however, for 
such cases are then limiting since the rooms would become narrower and/or the pillars wider to achieve an acceptable extraction ratio. This would lead to lower temperatures and thermomechanical stresses.

It is tempting to use the thermal loading as a design point, since al1 the thermal constraints seem to be met at $19.7 \mathrm{~kW} / \mathrm{acre}$. This is misleading, however, as it is possible to have a thermal loading of $19.7 \mathrm{~kW} /$ acre and still violate a thermal constraint (Figure $4-5$ ). By altering the amount of waste per package and the spacing of the canisters as per Table 4-5, the spent fuel temperature limit was exceeded while the thermal loading remained at $19.7 \mathrm{~kW} /$ acre (20 MTHM/acre).

\subsection{IMPACTS OF VARIOUS ALTERNATIVES}

An important aspect of the waste disposal program is the recognition, definition, and evaluation of the interfaces that exist between the engineered waste package and the other components of the mined geologic repository system. Changing any one element in the system can affect the other components of the system. The actual design of the waste package will have an impact on virtually all aspects of the waste disposal system, from the waste form configuration to repository operations and decommissioning. In terms of the self-shielded waste package versus the borehole waste package, the design of the self-shielded waste package allows for hands-on operations and eliminates the need to have individual boreholes for each package (Cohen et al, 1977). The choice of medium will affect the size of the repository and how much waste can be emplaced in it. Cost will also vary as the components of the waste disposal system change. 


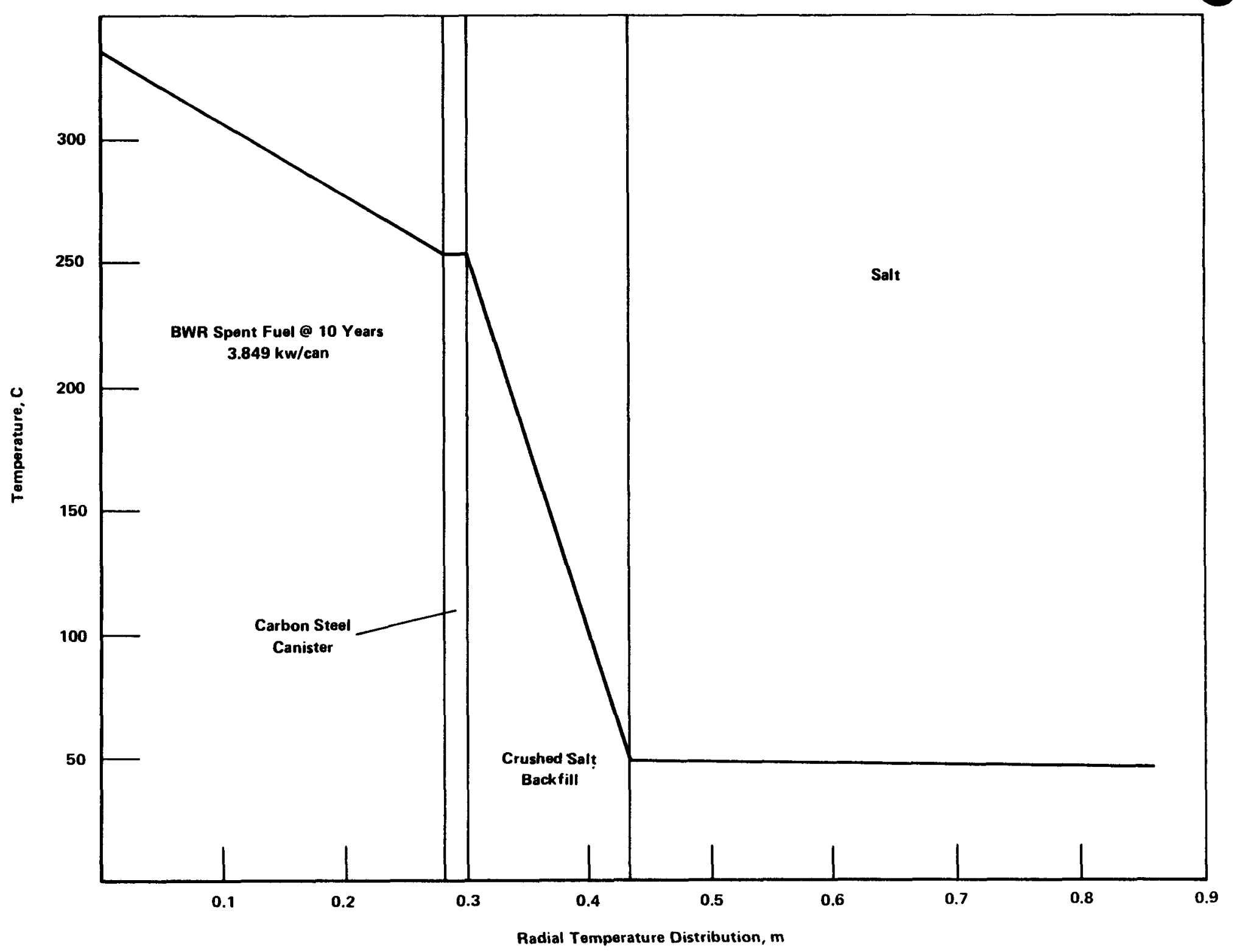

FIGURE 4-5. RADIAL TEMPERATURE DISTRIBUTION OF SPENT FUEL WASTE PACKAGE 
Table 4-5. Repository Characteristics

Characteristics

Specifications

Waste Description

Age of Waste, yr

Thermal Loading, W

Mass Loading, MTHM

Diameter of Pin, m

Active Length, m

10.0

2.86

0.0029

0.0062

4.0

Canister Description

Inner Diameter, $m$

Thermal Loading, $\mathrm{kW}$

0.28

3.849

Backfill Thickness, m

0.15

Room Description

Rows per Room

Row Separation, m

Hole Pitch, m

Adjacent Pillar Thickness, m

Canisters per Hole

$$
\begin{gathered}
2 \\
10.67 \\
37.68 \\
22.97 \\
1
\end{gathered}
$$

600.0

Materials

Waste

Canister

Backfil1

Medium
Depth, m

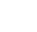


Table 4-6 1ists the results for some variations in canister loading and canister spacing of the repository configuration outlined in Table 4-2. In all cases if the $300 \mathrm{C}$ spent fuel limit was met, so were all the other temperature constraints. This leads to an hourglass view, Figure 4-6, of the interaction of the thermal criteria and possible design variations for a given situation. In this scheme, the applicable thermal limits for a given set of specifications, waste type, medium, repository location, etc., are obtained from the thermal criteria. The most restrictive thermal limits(s) can then be determined from these. After the most restrictive thermal limit(s) have been determined, various design options can be analyzed to find the optimum design. The most restrictive temperature 1 imit for the repository configuration in Table 4-2 is the $300 \mathrm{C}$ spent fuel limit during containment.

Cost is an important parameter in the optimization of the waste disposal system. Knowing the most restrictive thermal limit it is possible to attempt to optimize a given repository design with respect to cost. One parameter which could influence the cost of a repository is the age of the waste at disposal. Because the thermal power of the waste decreases over time, there may be a benefit from longer term storage of waste, prior to disposal. Figure 4-7 shows the decrease in peak spent fuel centerline temperature for the repository configuration in Table 4-2.

There are two possible ways to take advantage of the lower thermal power of aged spent fuel: (1) placing more waste in a canister, or (2) placing the canisters closer together. The benefit could take the form of reduced costs in mining and/or in packaging. Figure 4-8 illustrates 
Table 4-6. Canister Load and Spacing Varlations in the Repository Configuration of Table 4-2

\begin{tabular}{|c|c|c|c|c|c|c|c|}
\hline \multirow{2}{*}{$\begin{array}{l}\text { Waste } \\
\text { Age, yr }\end{array}$} & \multirow{2}{*}{$\begin{array}{l}\text { MTHM/ } \\
\text { Package }\end{array}$} & \multirow{2}{*}{$\begin{array}{l}\text { Inner } \\
\text { Radlus of } \\
\text { Canister, m }\end{array}$} & \multirow{2}{*}{$\begin{array}{l}\text { Row Sep- } \\
\text { aration, m }\end{array}$} & \multirow{2}{*}{$\begin{array}{l}\text { Hole } \\
\text { Pitch, m }\end{array}$} & \multicolumn{3}{|c|}{ Temperature, C } \\
\hline & & & & & Centerline & Canister & Medium \\
\hline 100 & $\begin{array}{c}3.9 \\
3.9 \\
3.9 \\
2.7 \\
2.7 \\
2.7 \\
2.7 \\
2.7 \\
2.7 \\
2.7 \\
2.7 \\
3.3 \\
2.7 \\
2.7 \\
14.5 \\
14.5 \\
14.5 \\
18.0 \\
18.85 \\
18.85 \\
23.0 \\
23.0\end{array}$ & $\begin{array}{l}0.280 \\
0.280 \\
0.280 \\
0.232 \\
0.232 \\
0.232 \\
0.232 \\
0.232 \\
0.232 \\
0.232 \\
0.232 \\
0.257 \\
0.232 \\
0.232 \\
0.540 \\
0.540 \\
0.540 \\
0.601 \\
0.615 \\
0.615 \\
0.680 \\
0.680\end{array}$ & $\begin{array}{r}15.67 \\
10.67 \\
5.67 \\
15.67 \\
10.67 \\
15.67 \\
10.67 \\
5.67 \\
4.67 \\
4.67 \\
5.67 \\
4.67 \\
10.67 \\
10.67 \\
4.67 \\
5.67 \\
10.67 \\
15.67 \\
21.67 \\
46.67 \\
15.67 \\
10.67\end{array}$ & $\begin{array}{r}40.66 \\
37.68 \\
9.67 \\
27.71 \\
37.68 \\
40.66 \\
25.65 \\
9.67 \\
17.46 \\
14.25 \\
6.51 \\
17.46 \\
37.70 \\
25.65 \\
17.49 \\
9.56 \\
37.70 \\
40.66 \\
47.28 \\
66.60 \\
40.66 \\
37.70\end{array}$ & $\begin{array}{c}330 \\
336 \\
362 \\
259 \\
262 \\
259 \\
263 \\
280 \\
279 \\
280 \\
286 \\
320 \\
92.4 \\
93.9 \\
276 \\
278 \\
252 \\
284 \\
289 \\
277 \\
337 \\
346\end{array}$ & $\begin{array}{c}247 \\
253 \\
278 \\
202 \\
205 \\
201 \\
206 \\
223 \\
222 \\
223 \\
286 \\
250 \\
77.2 \\
78.3 \\
192 \\
195 \\
167 \\
179 \\
179 \\
170 \\
202 \\
211\end{array}$ & $\begin{array}{l}41.4 \\
46.9 \\
73.6 \\
38.9 \\
41.6 \\
37.7 \\
41.3 \\
60.0 \\
58.5 \\
60.1 \\
65.0 \\
64.9 \\
33.6 \\
33.8 \\
74.3 \\
77.2 \\
48.7 \\
45.5 \\
40.8 \\
34.4 \\
49.0 \\
58.8\end{array}$ \\
\hline
\end{tabular}




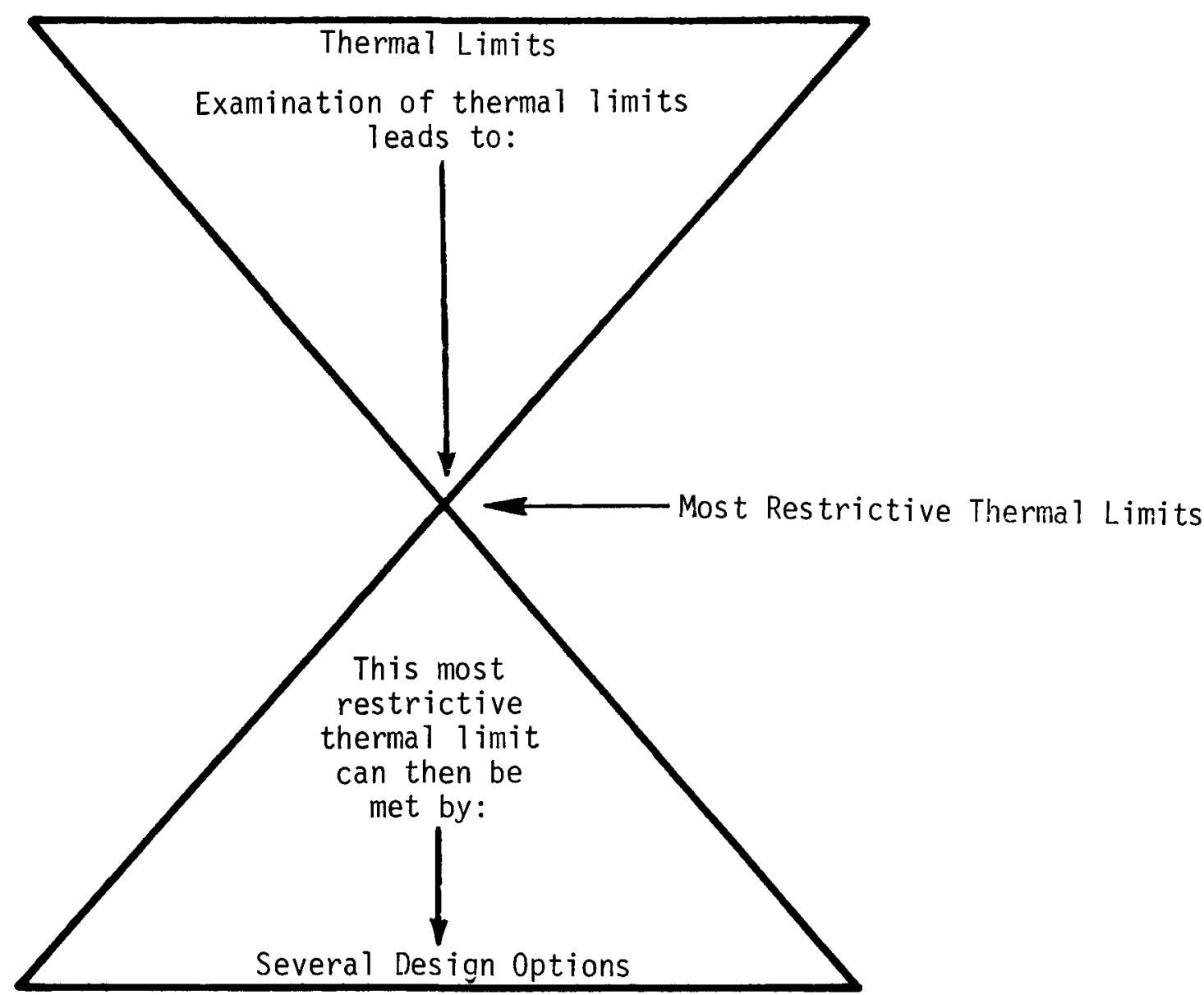

FIGURE 4-6. AN HOUR-GLASS VIEW OF THE INTERACTION OF THE THERMAL CRITERIA AND THE DESIGN OPTIONS 


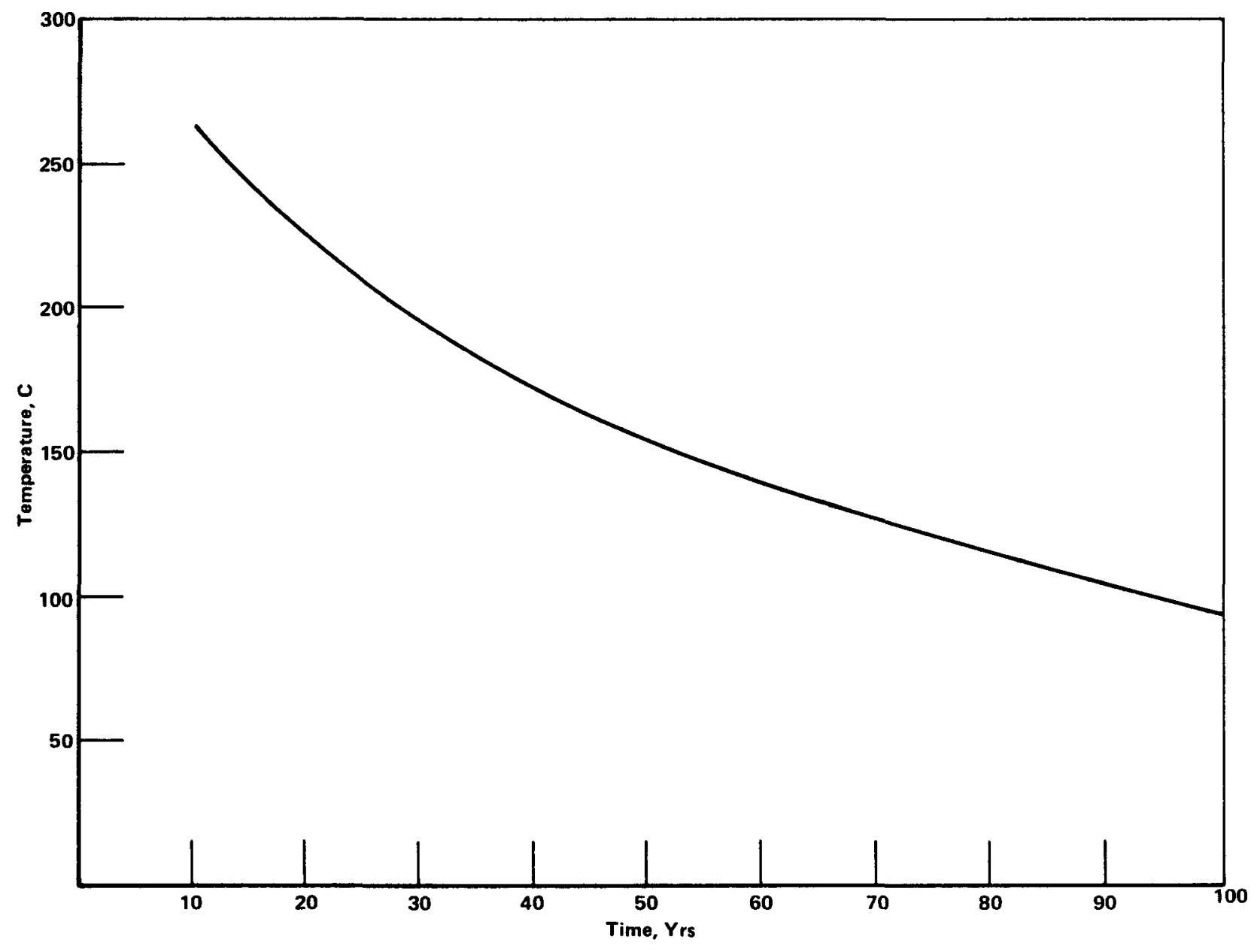

FIGURE 4-7. VARIATION OF SPENT FUEL CENTERLINE TEMPERATURE WITH TIME FOR THE REPOSITORY CONFIGURATION IN TABLE 4-2 


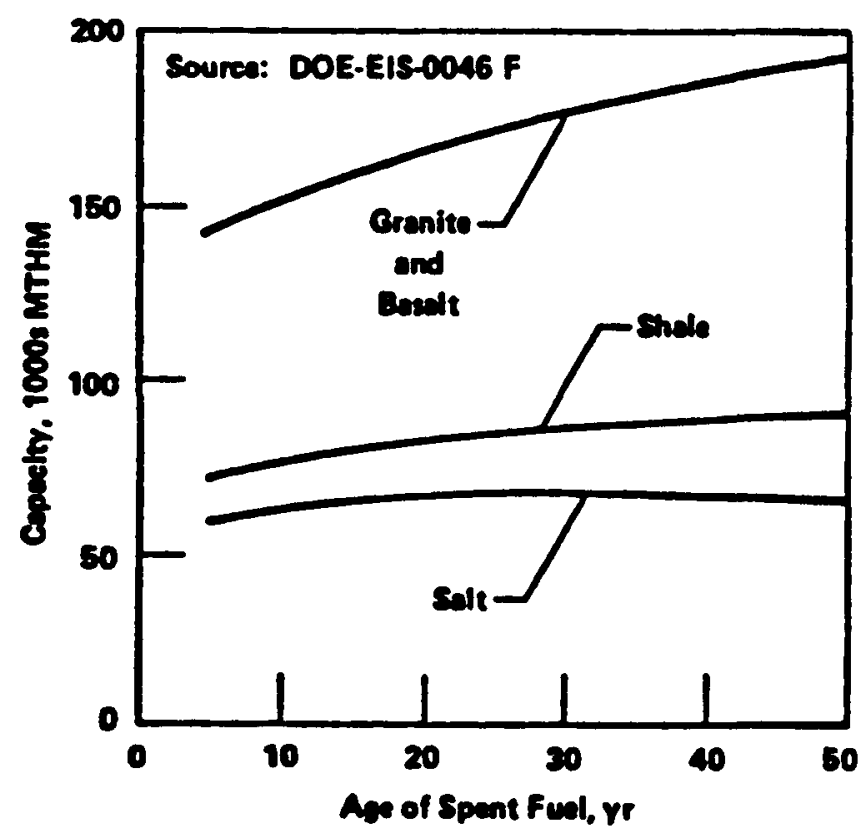

FIGURE 4-8. EFFECT OF SPENT FUEL AGE ON REPOSITORY CAPACITIES FOR THE ONCE-THROUGH CYCLE AND 2,000-ACRE REPOSITORIES 
the possible advantage of placing the canisters closer together. Additional cooling of the spent fuel could reduce the area required to dispose of the same number of spent fuel elements by 5 to 30 percent, depending on the geologic medium (U.S. Department of Energy, 1979).

Changing only the age of the waste to 100 years, the repository configuration in Table 4-2 was again analyzed. The results of this analysis are shown in Figures $4-9$ and 4-10. Figure 4-9 shows the radial temperature distribution of the spent fuel canister. Figure 4-10 shows the variation of the spent fuel centerline temperature with time after emplacement. The peak spent fuel centerline, canister, and emplacement area temperatures are well below their maximum permissible values shown in Table 4-3. At a distance of 0.86 meters the medium temperature is well below $75 \mathrm{C}$ and declining, thereby assuring that the near- and far-field medium limits will be met (Figure 4-9). Since the maximum spent fuel centerline temperature is less than $100 \mathrm{C}$ it is reasonable to assume that the spent fuel temperature at the end of the containment period is less than the $100 \mathrm{C} 11 \mathrm{mit}$.

The results presented in Figures 4-3 and 4-4 indicate that the amount of waste placed in the canister could be increased slightly without violating the temperature limits in Table 4-3. Figures 4-9 and 4-10, however, indicate that a potentially significant increase in the amount of waste that can be placed in the canister could be realized by cooling the waste for an additional 90 years. To evaluate the possible increases in the amount of waste per canister, the spacing between the canisters and the amount of waste per canister were varied until the most restrictive temperature 1 imit, the $300 \mathrm{C}$ spent fuel temperature, was reached. Figures 4-11 and 4-12 show the results of this analysis 


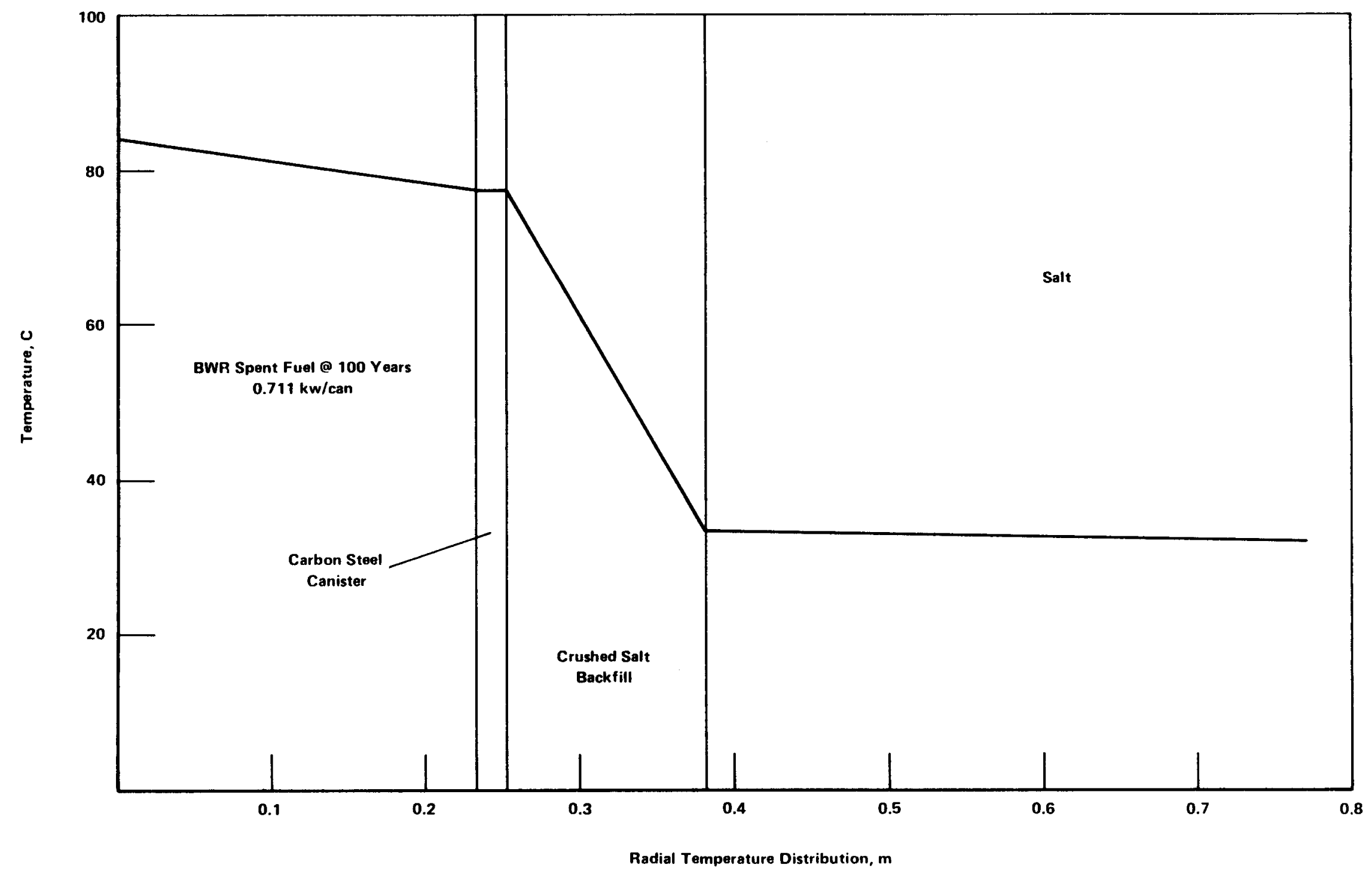

FIGURE 4-9. RADIAL TEMPERATURE DISTRIBUTION OF SPENT FUEL WASTE PACKAGE 


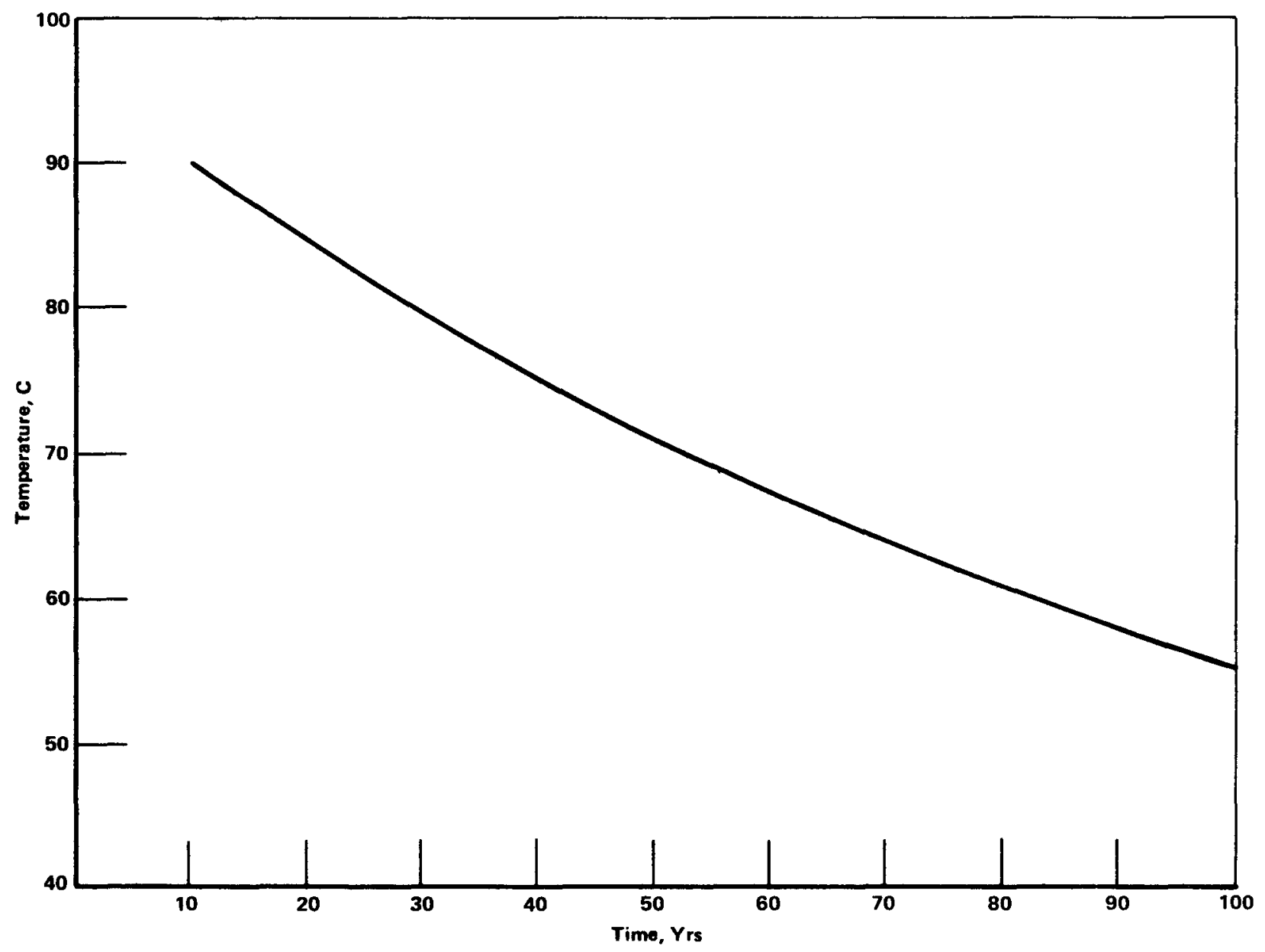

FIGURE 4-10. VARIATION OF SPENT FUEL CENTERLINE TEMPERATURE WITH TIME AFTER EMPLACEMENT 


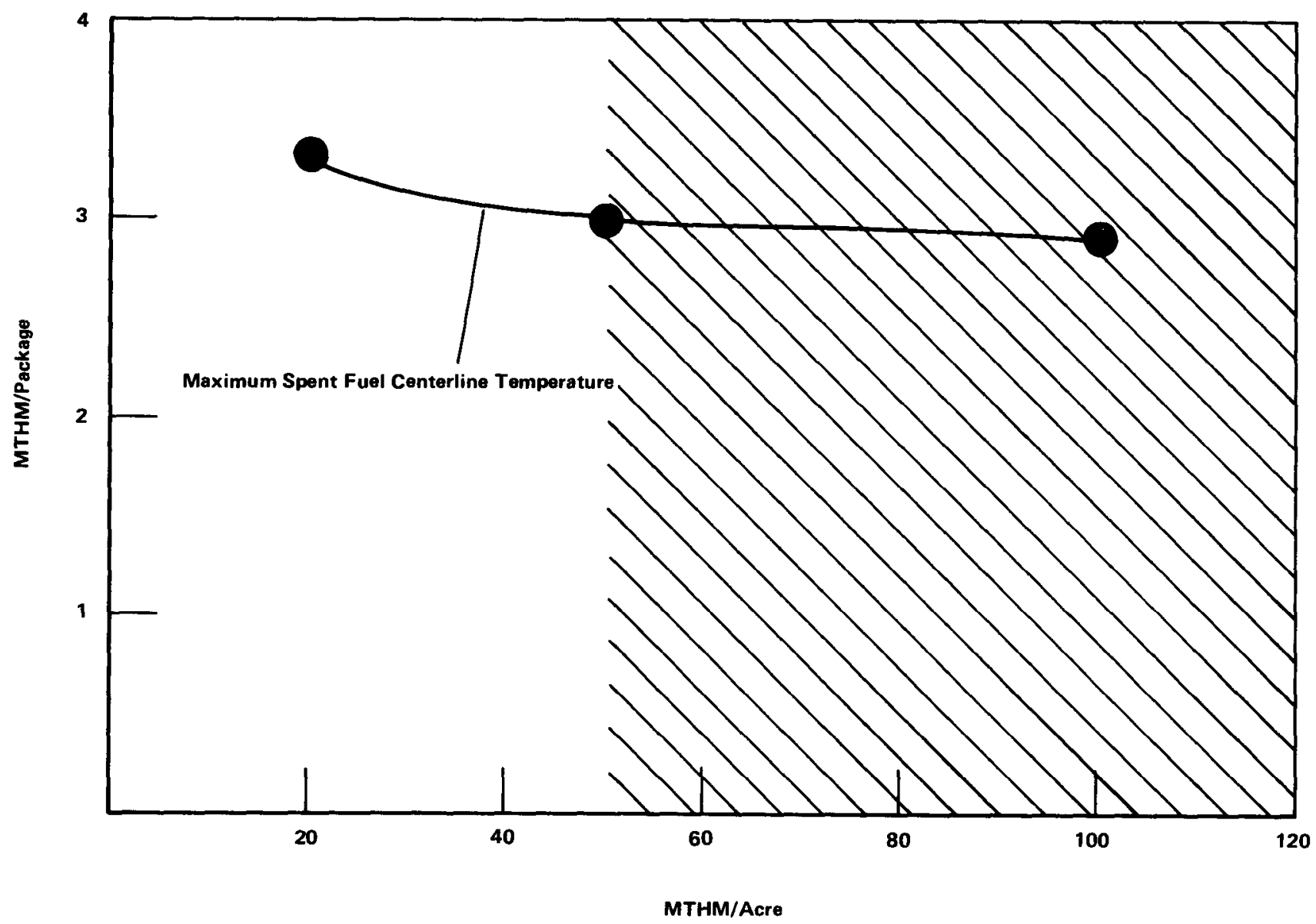

FIGURE 4-11. MAXIMUM AMOUNT OF BWR SPENT FUEL, COOLED 10 YEARS, THAT CAN BE PLACED IN A WASTE PACKAGE WITHOUT VIOLATING THE SPENT FUEL CENTERLINE TEMPERATURE LIMIT 


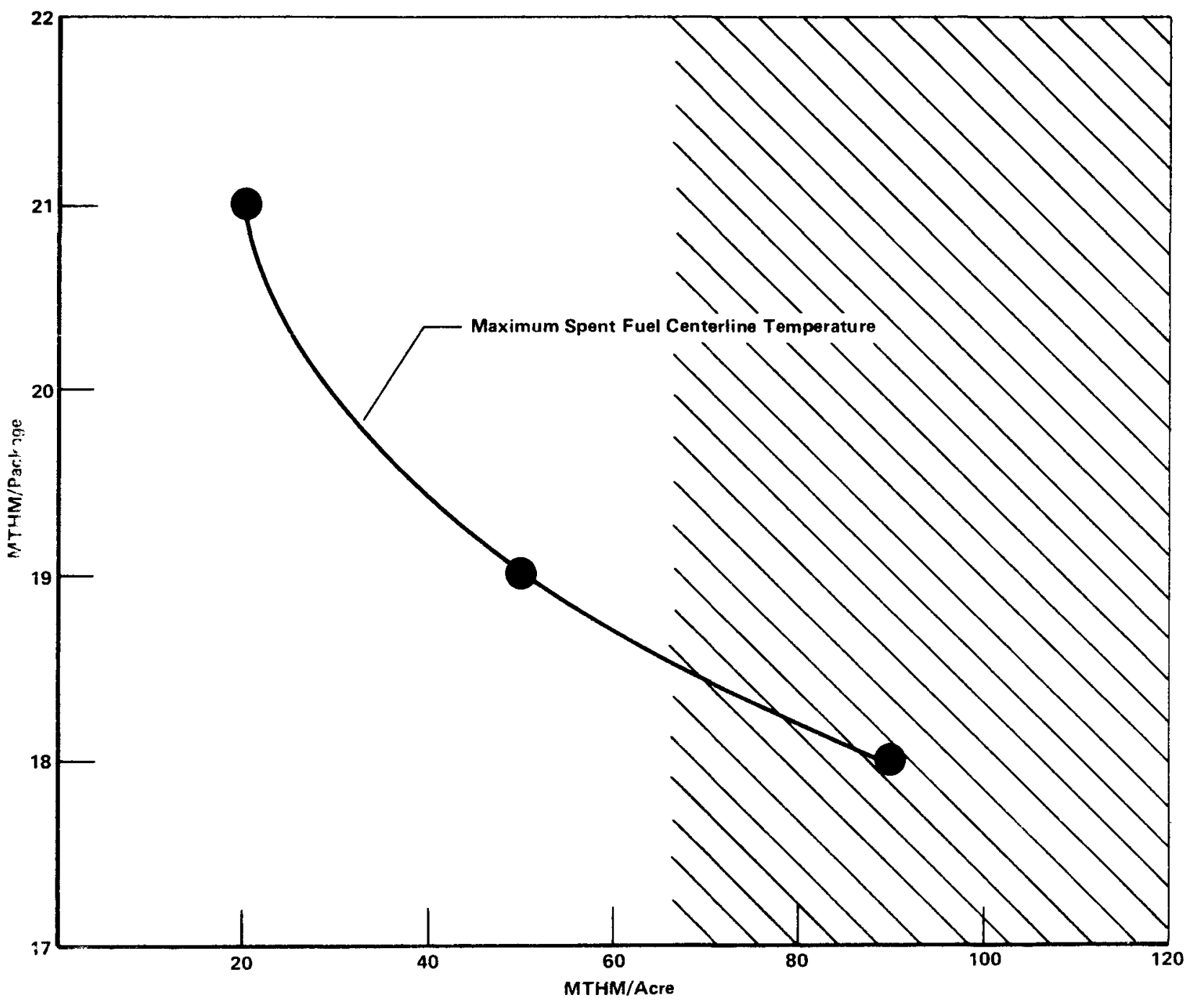

FIGURE 4-12. MAXIMUM AMIOUNT OF BWR SPENT FUEL, COOLED 100 YEARS, THAT CAN BE PLACED IN A WASTE PACKAGE WITHOUT VIOLATING THE SPENT FUEL CENTERLINE TEMPERATURE LIMIT 
for 10- and 100-year-old BWR spent fuel in salt. The cross-hatching in each of the figures indicates the point at which the total energy released into the formation becomes the most restrictive thermal 1 imit. As can be seen from Figure 4-11, the maximum amount of 10-yearold BWR spent fuel that can be placed in a single canister without violating the spent fuel centerline temperature limit ranges from $3.3 \mathrm{MTHM} /$ package $(1,138 \mathrm{pins})$ at $20 \mathrm{MTHM} /$ acre to about $2.9 \mathrm{MTHM} / \mathrm{package}$ (1,000 pins) at $50 \mathrm{MTHM} / \mathrm{acre.} \mathrm{Most} \mathrm{current} \mathrm{design} \mathrm{studies,} \mathrm{therefore,}$ could increase the amount of waste they place in a single package. Approximately six times more waste could be placed in a single canister, however, if the BWR spent fuel were cooled an additional 90 years (Figure 4-12). This could significantly reduce the number of packages required to dispose of the same amount of BWR spent fuel cooled only 10 years. The cross-hatching in both Figures 4-11 and 4-12 indicates the point at which the far-field limit dominates.

With the current design of long-lived packages, which represents a large portion of the total cost of a repository, a cost savings of only a few percent would be realized by reducing the area required for a repository. By placing more waste in a package, however, a potentially significant cost savings could occur. Mining of boreholes, package fabrication, and package handling costs are reduced when fewer packages are required. For spent fuel cooled 100 years, a potential cost savings of approximately 30 percent has been calculated (Waddell et al, 1981). Over one-third of the cost reduction was due to savings in package materials. However, any cost advantages realized by this additional cooling of the waste may be counterbalanced by the added cost and hazard of long-term storage prior to permanent disposal. 
By understanding the thermal constraints that apply to a given repository configuration, it is possible to evaluate the acceptability of the repository design, as was shown in the first section of this chapter. It is also possible to vary the repository characteristics in an attempt to optimize the design, as was shown in the latter part of this chapter. Although this analysis dealt with the impacts of waste age, similar analyses could be performed to evaluate the impacts of different waste package designs, canister materials, backfill materials, canister spacings, room and pillar designs, media, etc. In all cases the thermal criteria hierarchy developed in Chapter 3 can be used to determine the appropriate thermal constraints by which to evaluate a particular design. 
5 CONCLUS ION AND RECOMMENDATIONS

Two major points are provided by this report towards understanding the thermal impacts on the mined geologic disposal system that result from the thermal energy release of the emplaced wastes. The first is the summary of the thermal limits in current use (presented in Chapter 2) which have been placed on various aspects of the waste disposal system. The second point is the development of the thermal criteria hierarchy in Chapter 3. By identifying the aspects of the waste disposal system that are adversely affected by increased temperatures and how these areas interrelate, it is possible to evaluate the thermal acceptability of a given repository design.

Directly related to the thermal criteria hierarchy in Chapter 3 is the parametric analysis shown in Chapter 4. Th1s type of analysis can identify those aspects of repository design that are heavily influenced by the thermal energy release of the emplaced wastes. Through this information, possible repository designs could be optimized in terms of effectiveness, safety, cost, etc.

Before the thermal criteria hierarchy developed in Chapter 3 can realize its full potential, the concept of such a hierarchy of thermal limits must be accepted and used. Also, for this thermal criteria hierarchy to realize its full usefulness, the missing thermal limits must be determined. These missing thermal limits include such items as the effect of increased temperatures on cantster corrosion, the volatility of the wastes, the migration of ground water towards heat 
sources, and medium canister waste form interactions. Care should be taken in determining these temperature limits so that they are consistent with other limits in the hierarchy. As other failure mechanisms are identified they should be incorporated into the thermal criteria hierarchy.

The limits, of course, are not enough in themselves. One must also have accurate physical property data to evaluate site-specific repository designs. 
REFERENCES

Ad Hoc Panel of Earth Scientists, 1978. State of Geological Knowledge Regarding Potential Transport of High-Level Radioactive Waste From Deep Continental Repositories, EPA/520/4-78-004, U.S. Environmental Protection Agency, Washington, DC.

Ahlstrom, P. E., 1979. Ceramic and Pure-Metal Canisters in Buffer Metal, NUREG/CP-0005, U.S. Nuclear Regulatory Commission, Washington, DC.

American Society for Testing and Materials, 1978. Significance of Tests and Properties of Concrete and Concrete-Making Materials, Special Technical Publication, Philadelphia, PA, December.

Atlantic Richfield, Hanford Company, and Kaiser Engineers, 1977. Retrievable Surface Storage Facility Conceptual Design Description, ARH-LD-140, Informal Report, Rev., March.

Blackburn, L. D., D. G. Farwick, S. R. Fields, L. A. James, and R. A. Moen, 1978. Maximum Allowable Temperature for Storage of Spent Nuclear Reactor Fuel, HEDL-Tme 78-37, Hanford Engineering Development Laboratory, Interim Report, Richland, WA.

Braithwaite, J. W., and M. A. Molecke, 1979. Nuclear Waste Canister Corrosion Studies Pertinent to Geologic Isolation, SAND74-1935J, Sandia National Laboratories, Albuque rque, NM.

Burns, R. H., 1971. "Solidification of Low- and Intermediate-Leve1 Wastes", Atomic Energy Review, Vo1. 9(3), Vienna, Austria, September.

Cheverton, R. D., and W. D. Turner, 1972. Thermal Analysis of the National Radioactive Waste Repository: Progress Through March 1972, ORNL-4789, Oak Ridge National Laboratory, Oak Ridge, TN, September. 
Cohen, J. J., et al, 1977. Determination of Performance Criteria for High-Level Solidified Nuclear Waste, NUREG-0279, Lawrence Livermore Laboratory, Livermore, CA, July.

Columbo, P., and R. M. Neilson, 1977. Properties of Radioactive Waste Containers, BNL-NUREG-50692, Brookhaven National Laboratory, Upton, NY, August.

Cordfunke, E.H.P., 1969. The Chemistry of Uranium, Elsevier Publishing Company, NY.

Dames and Moore, 1978. Thermomechanical Stress Analysis and Development of Thermal Loading Guidelines, Y/OWI/TM-36120, Union Carbide, Oak Ridge, TN.

Dence, M. R., 1979. Mineral Stabilities and Rock Properties in Relation to Nuclear Waste Disposal, Technical Record, TR-1, Atomic Energy of Canada Limited, Pinawa, Manitoba.

Gilmore, W. R., ed., 1977. Radioactive Waste Disposal Low and High Level, Noyes Data Corporation, Park Ridge, NJ.

International Atomic Energy Agency, 1970. Bituminization of Radioactive Wastes, Technical Reports Series No. 116, International Atomic Energy Agency, Vienna, Austria.

Jacobsson, A., 1977. A Short Review of the Formation, Stability and Cementing Properties of Natural Zeolites, KBS Technical Report 27, KBS Scientific, Stockholm, Sweden.

Jenks, G. H., 1977. Maximum Acceptable Temperature of Wastes and Containers During Retrievable Geologic Storage, Y/OWI/TM-42, Oak Ridge, TN, August 17. 
Jenks, G. H., 1979. Effects of Temperature, Temperature Gradients, Stress, and Irradiation on Migration of Brine Inclusions in a Salt Repository, ORNL-5526, Oak Ridge National Laboratory, Oak Ridge, TN, July.

Kaiser Engineers, 1980. Retrieval Options Study, ONWI-63, prepared for Office of Nuclear Waste Isolation, Battelle Memorial Institute, Columbus, $\mathrm{OH}$, March.

Kaufman, D. W., 1960. Sodium Chloride - The Production and Properties of Salt and Brine, Reinhold Publishing Corporation, New York, NY.

Klett, R. D., E. S. Hertel, and A. E. Mo11y, 1980. System Engineering Programs for Geologic Nuclear Waste Disposa1, SAND80-0440, Sandia National Laboratories, Albuquerque, NM, June.

Lokken, R. 0., 1978. A Review of Radioactive Waste Immobilization in Concrete, PNL-2654, Pacific Northwest Laboratory, Richland, WA, June.

McCarthy, G. J., W. B. White, B. Roy, B. E. Schutz, S. Komarneni, D. K. Smith, and D. M. Roy, 1978. "Interactions Between Nuclear Waste and Surrounding Rock", Nature, Vo1. 273, May.

Mendel, J. E., 1978. The Storage and Disposal of Radioactive Waste as Glass in Canisters, PNL-2764, Pacific Northwest Laboratory, Richland, WA, December.

Miller, N. W., and K. J. Wurm, 1980. Package Design Guidance - A Topical Report, ONWI/SUB/80/E516-03300-3, Battelle Memorial Institute, Columbus, $\mathrm{OH}$, March.

National Institute for Occupational Safety and Health (NIOSH), 1972. "Criteria for Recommended Standards - Occupational Exposure to Hot Environments", U.S. Department of Health, Education, and Welfare Publication No. H5M 72-10268. 
O'Hara, F. A., K. R. Yates, R. Christensen, J. W. Droege, U. Y. Park, K. J. Wurm, W. J. Zielenbach, and C. R. Reinhart, 1979. Characterization of Class A Waste From the Commercial Fuel Cycle, ONWI-6(2), prepared by Battelle's Columbus Laboratories for Office of Nuclear Waste Isolation, Battelle Memorial Institute, Columbus, $\mathrm{OH}$.

Olander, D. R., A. J. Machiels, and S. Yagnik, 1980. Thermal Gradient Migration of Brine Inclusions in Salt, ONWI-208, prepared by the Regents of the University of California for Office of Nuclear Waste Isolation, Battelle Memorial Institute, Columbus, $\mathrm{OH}$.

Rockwell International, 1979. Package Design Criteria for Commercial Waste and Spent Fuel Packaging Program, RHO-CD-772, Rockwell Hanford Operations, Richland, WA, August.

Russe11, J. E., 1977. Areal Thermal Loading Recommendations for Nuclear Waste Repositories in Salt, Y/OWI/TM-37, Union Carbide, Oak Ridge, TN.

Science Applications, Inc., 1976. The Selection and Evaluation of Thermal Criteria for a Geologic Waste Isolation Facility in Salt, Y/OWI/SUB-76-07220, Oak Ridge, TN, September.

Science Applications, Inc., 1978. Thermal Analyses, Y/OWI/TM-36119, Oak Ridge, TN, April.

Science Applications, Inc., 1979. Storage Room Design Parameters for the ONWI Spent Fuel Disposal Study: Nine Case Studies in Salt, ONWI/78/SUB-E513-00413-1, Oak Ridge, TN, March 23.

Smith, M. J., et al, 1980. Engineered Barrier Development for a Nuclear Waste Repository in Basalt: An Integration of Current Knowledge, RHO-BWI-ST-7, Rockwell Hanford Operations, Richland, WA, May. 
Turcotte, R. P., and J. W. Wald, 1978. Devitrification Behavior in a Zinc Borosilicate Nuclear Waste Glass, PNL-2247, Pacific Northwest Laboratory, Richland, WA, March.

U.S. Department of Energy, 1979. Environmental and Other Evaluation of Alternatives for Long Term Management of Stored INEL Transuranic Waste, DOE/ET-0081, Washington, DC, February.

U.S. Department of Energy, 1980. Management of Commercially Generated Radioactive Waste: Final Generic Environmental Impact Statement, Vo1s. 1, 2, DOE/EIS-0046F, Washington, DC, October.

U.S. Department of Energy, 1981. NWTS Program Criteria for Mined Geologic Disposal of Nuclear Waste: Site Performance Criteria, DOE/NWTS-33(2), Office of NWTS Integration, Battelle Memorial Institute, Columbus, OH, February.

U.S. Department of Energy, 1982a. NWTS Program Criteria for Mined Geologic Disposal of Nuclear Waste: Program Objectives, Functional Requirements, and System Performance Criteria, DOE/NWTS-33(1), Office of NWTS Integration, Battelle Memorial Institute, Columbus, $\mathrm{OH}$, March.

U.S. Department of Energy, 1982b. NWTS Program Criteria for Mined Geologic Disposal of Nuclear Waste: Repository Performance and Development Criteria, DOE/NWTS-33(3), Office of NWTS Integration, Battelle Memorial Institute, Columbus, $\mathrm{OH}$, July, Public Draft.

U.S. Department of Energy, 1982c. NWTS Program Criteria for Mined Geologic Disposal of Nuclear Waste: Functional Requirements and Performance Criteria for Waste Packages for Solidified High-Level Waste and Spent Fuel, DOE/NWTS-33(4a), Office of NWTS Integration, Battelle Memorial Institute, Columbus, $\mathrm{OH}$, July, Public Draft.

U.S. Energy Research and Development Administration, 1976. Alternatives for Managing Wastes From Reactors and Post-Fission Operations in the LWR Fuel Cycle, 5 volumes, ERDA-76-43. 
U.S. Nuclear Regulatory Commission, 1981. "Disposal of High-Leve1 Radioactive Wastes in Geologic Repositories", 10 CFR Part 60, Proposed Rule, Federal Register, Vo1. 46, No. 130, July. 
APPENDIX A

GLOSSARY OF TERMS

*U.S. Department of Energy, Management of Commercially Generated Radioactive Waste, Vol 1,2, DOE/EIS-0046F, October 1980. 


\section{GLOSSARY OF KEY TERMS AND ACRONYMS}

Abiotic: characterized by the absence of life.

Abyssal Hill: relatively small topographic feature of the deep ocean floor ranging to 600 to $900 \mathrm{~m} \mathrm{high}$ and a few kilometers wide.

Actinides: Radioactive elements with atomic number larger than 88.

Activation: The process of making a material radioactive by bombardment with neutrons, protons, or other nuclear particles.

Activity: A measure of the rate at which radioactive material is emitting radiation; usually given in terms of the number of nuclear disintegrations occurring in a given quantity of material over a unit of time. The special unit of activity is the curie (Ci).

AFR: Away-from-reactor (spent fuel storage concept).

Aging: Usually refers to time to permit decay of short-lived radionuclides.

ALAP: As low as practicable, now generally replaced with ALARA (as low as reasonably achievable).

ALARA: As low as reasonably achievable. ALARA refers to limiting release and exposure and is used by the NRC (10 CFR 50.34) in the context of ". . as low as reasonably achievable taking into account the state of technology, and the economics of improvements in relation to benefits to the public health and safety and other soctetal and socioeconomic considerations. ."

Allowance Item: A number, arrived at by judgement, that represents material or equipment cost that cannot be developed otherwise because of the absence of design detail.

Alluvial Fan: A sloping, fan-shaped mas's of loose rock material deposited by a stream at the place where it emerges from an upland onto a broad valley or a plain.

Alluvium: All detrital material deposited permanently or in transit by streams.

Alpha Particle: A positively charged particle emitted by certain radioactive material. It is made up of two neutrons and two protons; hence it is identical with the nucleus of a helium atom.

Amphibole: A group of dark, rock-forming, ferromagnesian silicate minerals which are closely related in crystal form and composition and which have abundant and wide distribution in igneous and metamorphic rocks.

Andesitic: A volcanic rock composed primarily of the plagioclase feldspar andesine and one or more mafic constituents.

Anion: An ion that is negatively charged.

Anticline: A fold, the core of which contains stratigraphically older rocks, which in simplest form is elongate and convex upward with the two limbs dipping away from each other.

APS: Atmospheric protection system.

Aquifer: A water-bearing layer of permeable rock or soll that will yield water in usable quantities to wells. 
Aquitard: A natural rock or soil of low permeability which is stratigraphically adjacent to one or more aquifers and through which water movement is markedly retarded or impeded.

Argillaceous: Containing or pertaining to clay.

Artesian: When pertaining to an aquifer, it is one that is confined so that its hydraulic head rises above the top of the aquifer unit; thus an artesian water body is one that is confined under hydrau tic pressure.

Atom: An electrically neutral particle of matter, indivisible by chemical means.

Atomic Number: The number of protons within an atomic nucleus.

Atomic Weight: The mass of an atom relative to other atoms.

Back End of the Fuel Cycle: Includes spent fuel storage, fuel reprocessing, mixed-oxide fuel fabrication, and waste management.

Background Radiation: The radiation in man's natural and undisturbed environment. It results from cosmic rays and from the naturally radioactive elements of the earth, including those from within the human body.

Basement Rock: A complex of undifferentiated rocks that underlies the oldest identifiable rocks in the area.

Basin: A depressed area generally having no outlet for surface water.

Batholith: A shield-shaped mass of igneous-intruded rock, greater than $100 \mathrm{~km}^{2}$ in area, extending to great depth and whose diameter increases with depth.

Bedrock: A solid rock formation usually underlying one or more other loose formations.

Benthic: Refers to the bottom of a body of water.

Bebtonitic: Pertaining to rock containing bentonite, a clay formed from the decomposition of volcanic ash.

Biosphere: The part of the earth in which life can exist, including the lithosphere, hydrosphere, and atmosphere; living beings together with their environment.

Biota: The animal and plant life of a region.

Biotite: A complex silicate of aluminum, potassium, magnesium, and iron with hydroxyl that is a widely distributed and important rock-forming mineral of the mica group.

Block-Faulting: A type of vertical faulting in which the crust is divided into structural or fault blocks of different elevations and orientations.

Boiling Water Reactor (BWR): A reactor system that uses a boiling water primary cooling system. Primary cooling system steam turns turbines to generate electricity.

Borosilicate Glass: A silicate glass containing at least 5 percent bor ic acid and used to vitrify calcined waste.

Breccia: A course-grained clastic rock composed of 1 arge, angular, and broken rock fragments cemented together in a finer grained matrix.

Burial Grounds: Areas designated for disposal of containers of radioactive wastes and obsolete or worn-out equipment by near-surface burial.

Caicine: Material heated to a temperature below its melting point to bring about loss of moisture and oxidation.

Canister: A metal container for radioactive solid waste. 
Cask: A container that provides shielding and containment during transportation of radioactive materials.

Catastrophic: A violent, sudden or unexpected event which results in failure of the predicted performance of a system or component.

Cation: An ion that is positively charged.

Cation Exchange Chromatography (CEC): A process for separating several cations using the differences in the rate they travel on an ion exchange column.

Cermet: A material made by combining a heat resistant ceramic with a metal usually made by powder metallurgy.

CH-TRU: Contact-handled TRU waste.

Clastic: Pertaining to or the state of being a rock or sediment composed principally of broken fragments derived from preexisting rocks or minerals.

Colocated: Refers to location of facilities at a common site.

Concentration Guide: The average concentration of a radionuclide in air or water to which a a worker or member of the general public may be continuously exposed without exceeding radiation dose standards.

Consolidated (material): In geology, natural materials that have been made firm, cohesive, and hard.

Contact-Handled Waste: Waste package having surface dose rate less than $0.2 \mathrm{R} / \mathrm{hr}$. Such packages can be handled by workers without extensive shielding. Contact-handled wastes were termed low-level wastes in DOE/ET-0028 and DOE/ET-0029.

Containment: Confining the radioactive wastes within presented boundaries, e.g., within a waste package.

Contingency (cost): The amount of money added to the estimated cost of a project to cover certain areas of cost uncertainty and reduce the probability of understating the project cost estimate. With the contingency added, there is a more nearly equal probability of a cost underrun or overrun.

Cost of Money: Weighted cost of debt and equity financing. Cost of money is used synonymously with cost of capital.

Critical Mass: The mass of fissionable material of a particular shape that is just sufficient to sustain a nuclear chain reaction.

Criticality: The condition in which a nuclear reactor is just self-sustaining.

Crystalline Rock: An inexact but convenient term designating an igneous or metamorphic rock, as opposed to a sedimentary rock.

Curie $(C i)$ : A special unit of activity where $1 \mathrm{Ci}$ equals $3.7 \times 10^{10}$ spontaneous nuclear disintegrations per second.

Daughter Nuclide: A nuclide formed upon disintegration of a parent radionuclide.

Decomissioning: Preparations taken for retirement from active service of nuclear facilities, accompanied by the execution of a program to reduce or stabilize radioactive contamination. The objective of decommissioning is to place the facility in such a condition that future risk to public safety from the facility is within acceptable bounds.

Decontamination: The selective removal of radioactive material from a surface or from within another material. 
Decontamination Factor (DF): The ratio of the original contamination level to the contamination level after decontamination.

Deep Continental Geologic Formations: Geologic media beneath the continents and isolated from the land surface by several hundred to thousands of meters of overlying rock material.

Depositional Environment (sedimentary environment): A geographically restricted environment where sediment accumulates under similar physical, chemical, and biological conditions.

Devitrification: The process by wich glassy substances lose their vitreous nature and become crystalline.

Diaprisim: The piercing of overlying rocks by an upward-moving mobile core or material, such as a salt body or an igneous intrusion.

Discharge: In ground-water hydrology, water that issues naturally or is withdrawn from an aqu ifer.

Disposal (radioactive waste): The planned release of radioactive waste in a manner which is considered permanent so that recovery is not provided for.

Dome: A dome-shaped landform or rock mass; a large igneous intrusion whose surface is convex upward with sides sloping away at low but gradually increasing angles; an uplift or an anticlinal structure, either circular or elliptical in outline, in which the rock dips gently away in all directions, for exanple, a salt dome.

Dissolution: In this context it refers to the dissolving of spent fuel by nitric acid as a process step in fuel reprocessing.

Dose: Here in generally means the more rigorous term "dose-equivalent." The latter, expressed in units of rem; implies a consistent basis for estimates of consequential health risk, regardless of rate, quantity, source, or quality of the radiation exposure.

DOT: U.S. Department of Transportation.

Dry Storage: Storage of waste packages without liquid cooling.

EIA: Energy Information Administration.

EPA: U.S. Environmental Protection Agency.

Epeirogeny: The broad movements of uplift and subsidence which affect whole or large portions of continents or ocean basins.

Fault: A fracture or fracture zone along which there has been displacement of the sides relative to one another parallel to the fracture.

Fault Block: A crustal unit either completely or partly bounded by faults.

Fault System: A system of parallel or nearly parallel faults that are related to a particular deformational episode.

Feldspar: Any of a group of comon rock-forming minerals that are silicates of alumina and some other base, such as potash, soda, or lime.

Fission (nuclear): The splitting of a nucleus into two or (rarely) more fragments; usually limited to heavier nuclei such as isotopes of uranium, plutonium, and thorium.

Fission Product: Any radioactive or stable nuclide produced by fission, including both primary fission fragments and their radioactive decay products.

Fissionable Material: Actinides capable of undergoing fission by interaction with neutrons of ail energies. 
FPF: Fuel packaging facility.

Fracture: breaks in rocks caused by intense folding or faulting or the process of breaking fluid-bearing strata by injecting a fluid under such pressure as to cause partings in the rock.

Freshwater Lens: A body of fresh water roughly shaped like a lens formed as a result of injecting freshwater into a salt water body or occurring naturally when precipitation infiltrates a saline aquifer.

Fuel (nuclear reactor): Fissionable material used as the source of power when placed in a critical arrangement in a nuclear reactor.

Fuel Cycle: Mining, refining, enrichment, and fabrication of fuel elements, use in a reactor, chemical processing to recover the fissionable material remaining in the spent fuel, reenrichment of the fue 1 material, refabrication of new fuel elements, and management of radioactive waste.

Fuel Element: A tube, rod, or other form into which fissionable material is fabricated for use in a reactor.

Fuel Reprocessing Plant (FRP): Plant where irradiated fuel elements are dissolved, waste materials removed, and reusable materials are segregated for reuse.

Fuel Residue Waste (FRW): Solid wastes consisting of the residue (fuel element hardware and chopped cladding material) after the bulk of fuel core material, including most of the actinides and fission products, has been dissolved in nitric acid.

Gamma Ray: Electromagnetic radiation, similar in nature to $x$-rays, emitted by the nuc le $i$ of some radioactive substances during radioactive decay.

GEIS: Generic Environmental Impact Statement.

Geohydrology: The study of the character, source, and mode of occurrence of underground water.

Geothermal: Pertaining to the heat of the interior of the earth.

Geothermal Gradient: The increasing temperature of the earth with depth.

GESMO: Generic Environmental Impact Statement on use of Mixed-0xide fuel in LWRs.

Granitic: of or pertaining to granite. Granite-like.

Granitoid: A textural term indicating grain size and mineral distribution typical of granite.

Ground Water: Water that exists or flows within the zone of saturation beneath the land surf ace.

Grout: A mortar fluid combined with liquid waste to provide a matrix for isolation of the waste and to seal the waste from the environment.

GWe: Gigawatts (billions of watts) of electrical generation; a rate of energy production.

Gyre: A large closed ringlike system of ocean currents which rotates in a circular motion in each of the major $\propto$ ean basins.

Half-Life: a) physical--the time required for quantity of a radioactive substance to decay to one-half of its original quantity. b) biological--time required for half of an ingested or inhaled substance to be eliminated from the body by natural process.

c) effective--time required for half of an ingested or inhaled radioactive substance to be eliminated from the body by the combination of radioactive decay and natural processes; mathematically equal to product of the physical and biological half-lives divided by the sum of the physical and biological half-lives. 
Head End of the Fuel Cycle: Mining, milling, enrichment, and fabrication of $\mathrm{UO}_{2}$ fuel.

HEPA: High-efficiency particulate air (filter).

High-Level Liquid Waste ( $H L L W$ ): The aqueous waste resulting from operation of the first cycle solvent extraction system (or its equivalent) in a facility for reprocessing irradiated reactor fuels as well as concentrated wastes from subsequent cycles.

High-Level Waste (HLW): DOE management directives define high-level waste to include highlevel liquid wastes, products from solidification of high-level liquid waste, and irradiated fuel elements if discarded without reprocessing. A proposed NRC regulation (10 CFR 60.3) defines high-level waste to include irradiated fuel, high-level liquid waste, and products from its solidification. In the GEIS there are instances, however, where discarded spent fuel and high-level waste (as wastes from the reprocessing of spent fuel) are cited separately.

Highly Enriched Uranium (HEU): Uranium containing $5 \%$ or more of added $235 U$.

HM: Heavy metal, generally uranium and plutonium.

Hornblende: A common member of the amphibole group of minerals.

Hot Cell: A facility which allows remote viewing and manipulation of radioactive substances.

Hydraulic Gradient: The change in static head per unit of lateral distance in a given direction.

Hydrologic: Pertaining to the study of the properties, distribution and circulation of water on the surface of the land, in the soil and underlying rocks, and in the atmosphere.

Hydrostatic Pressure: The pressure exerted by the water at any given point in a body of water at rest.

ICPP: Idaho Chemical Processing Plant.

ICRP: International Comission on Radiological Protection.

ILLW: Intermediate-level liquid waste.

Immobilization: Treatment and/or emplacement of the wastes so as to impede their movement.

Interim Storage: Storage operations for which a) monitoring and human control are provided and b) subsequent action involving treatment, transportation, or final disposition is expected.

Interstices: In geology, small openings between solid particles in a rock or unconsolidated material; may be a void or pore and often contains ground water. Interstitial permeability is used to differentiate interconnected pore permeability from fracture permeability.

Ion Exchange: Replacement of ions adsorbed on a solid, such as a clay particle, or exposed at the surface of a solid by ions from solution, usually in natural water. The phenomenon is known to occur when natural water moves through clays, zeolitic rocks, and other materials of the earth's crust.

ISFS: Independent spent fuel storage.

ISFSF: Independent spent fuel storage facility.

Isolation: Segregating wastes from the accessible environment (biosphere) to the extent required to meet applicable radiological performance objectives.

Joint: A fracture or parting in a rock, along which little or no displacement of rock material has occurred. 
Kaolinite: A common clay consisting mainly of hydrous aluminum silicate and closely related in chemical composition and crystal structure.

Kilowatt-hour (kWh): Use of electricity for one hour at a rate of 1000 watts.

Levelized Unit Cost: Capital and operating charges translated into an equivalent constant (or level) annual unit cost.

Light Water Reactor (LWR): May be either a BWR or PWR; uses as coolant ordinary water $\left(\mathrm{H}_{2} \mathrm{O}\right)$ instead of heavy water $\left(\mathrm{O}_{2} \mathrm{O}\right)$.

Lithification: The conversion of unconsolidated sediment into solid rock by processes such as compaction, cementation, and crystallization.

Lithology: The study of rocks. Also the character of a rock: its structure, color, mineral composition, grain size, and arrangement of its component parts.

Lithostatic pressure: The confining pressure at depth in the crust of the earth due to the weight of the overlying rocks.

Littoral: Belonging to, inhabiting or taking place on or near the shore of a body of water.

Low Enriched Uranium (LEU): Uranium containg less than $5 \%$ by weight but greater than $0.72 \%$ by we ight $235 \mathrm{U}$.

MBM Shaft: Men and Materials shaft at a mined repository.

Mafic: Pertaining to or composed dominantly of magnesium rock-forming silicates.

Magmatism: The development, movement, and solidification to igneous rock, of magma, a naturally occurring mobile rock material, generated within the earth and capable of intrusion and extrusion.

Maximum Individual, Maximum-Exposed Individual: A person whose location and habits tend to maximize his radiation dose.

Megawatts (MW): Millions of watts.

Mica: A group of silicate minerals of aluminium and other bases, especially potassium, magnesium, and iron, and characterized by great perfection of cleavage in one direction, that produces thin, tough, elastic plates.

Mixed-0xide Fuel Fabrication Plant (MOX-FFP): Plant where uranium oxide and plutonium oxide are mixed and fabricated into fuel elements for use in nuclear power plants.

Mox: Mixed oxides (of uranium and plutonium).

MTHM: Metric tons of heavy metal (usually refers to reactor fuel, in which the heavy metals are uranium and plutonium).

Mucking and/or Settling Ponds: Ponds next to drilling operations where the excavated mud or slurry is placed; the sediment that settles at the bottom of these ponds is called muck.

Multibarrier: A system using the waste form, the container (canister), the overpack, the emplacement medium, and surrounding geologic media as multiple barriers to isolate the waste from the biosphere.

NAS: National Ac ademy of Sciences.

NASA: National Aeronautics and Space Administration.

NCRP: National Council on Radiation Protection and Measurement. 
Neutron: Stable particle in a nucleus of very slightly greater mass than a proton but without nuclear change.

$\mathrm{NO}_{x}$ : Oxides of nitrogen, specifically $\mathrm{NO}$ and $\mathrm{NO}_{2}$.

NRC: Nuclear Regulatory Comission.

Nucleus: The inner core of the atom, consisting primarily of neturons and protons, which make up almost the entire mass of the atom but only a minute part of its volume.

Nuc lide: A species of atom characterized by its mass number, atomic number, and nuc lear energy state; to be regarded as a distinct nuclide the atom must be capable of existing for a measureable lifetime in its nuclear energy state.

0livine: An olive-green, common rock-forming ferromagnesian silicate mineral of mafic, Ultramafic, and low-silica igneous rocks.

ONWI: Office of Nuc lear Waste Isolation at Battelle Memorial Intitute, Columbus, Ohio; under contract to DOE.

Operations: Broad classification of waste management activities in terms of their basic function (e.g., waste storage, treatment, transportation or disposal).

ORNL: Oak Ridge National Laboratory.

Overpack: Secondary (or additional) external containment for packaged nuclear waste.

Outcrop: A part of a body of rock that appears, bare and exposed, at the surface of the ground.

Parent Nuclide: A radionuclide that upon disintegration yields a specified nuclide, either directly or as a later member of a radioactive decay series.

Partition: To separate one (or more) element(s) from one (or more) other element(s). ExamDles include the separation of uranium and plutonium from each other, the separation of actinides and fission products in the waste, and the separation of one fisson product from the other fission products.

Perihelion: The point in the orbit of a celestial body that is closest to the sun.

Permeability: The quality or state of being permeable. The relative ease with which a porous medium can transmit a liquid under a hydraulic gradient.

Peridotite: A coarse-grained plutonic igneous rock composed chiefly of the mineral olivine but also containing considerable amounts of other ferromagnesian minerals.

Plagioclase: The group of common rock-forming feldspar minerals; silicates of varying mixtures of sodium and calcium.

Pluton: A body of intrusive igneous rock of any shape or size.

Pluvial: Pertaining to a period of time in which rainfall or precipitation is abundant.

PNL: Pacific Northwest Laboratory operated for DOE by Battelle Memorial Institute.

Porosity: That property of a rock or soil which enables the rock or soil to contain water in voids or interstices, usually expressed in percentage or as a decimal fraction of void volume as compared to total volume.

Pressurized Water Reactor (PWR): A reactor system that uses a pressurized water primary cooling system. Steam formed in a secondary cooling system is used to turn turbines to generate electricity. 
Primary Wastes: Untreated initial wastes resulting from operation of fuel cycle facilities other than waste management $f a c i l i z i e s$ (wastes from operation of waste management facilities are secondary wastes).

Pyroxene: A group of dark rock-for-ing silic ate minerals closely related in crystal form and analogous in chemical composition to the amphiboies; found chiefly in igneous rocks.

Rad: Radiation absorbed dose, the basic unit of absorbed dose of ionizing radiation. A dose of 1 rad is equivalent to the absorption of 100 ergs of radiation energy per gram of absorbing material.

Recharge: In hydrology, a source or means for replenishment of water withdrawn or discharged from an aqu ifer.

rem (roentgen equivalent man): A quantity used in radiation protection to express the effective dose equivalent for all Forms of ionzing radiation. It is the product of the adsorbed dose in rads and factors related to relative biological effectiveness.

Remotely Handled Waste: Waste packeze having surface dose rate greater than $0.2 \mathrm{R} / \mathrm{hr}$. Such packages require extensive shielding and/or remote handling to protect operating personnel. Remotely handled wastes were termed intermediate-level wastes in DOE/ET-0028 and DOE/ET -0029.

Repository (Federal): A Federally owned and operated facility for storage or disposal of spec ific types of waste from DOE sites and/or licensees.

Retrievability: Capability to remove waste from its place in isolation with approximate Ty the same level of effort and radiation exposure as required to place the waste.

RH-TRU: Remotely handled TRU waste.

Risk (mathematical): Product of the consequences and the probability of the event's occurrence.

Roentgen: A un it for measuring garma or "x-ray" radiation. The Roentgen is defined by measuring the effect of the radiation on air. It is that amount of gamma or $x-r$ ays required to produce ions carrying i electrostatic unit of charge in $0.001293 \mathrm{~g}$ of dry air under standard conditions; $1 \mathrm{R}=2.58 \times 10^{-4} \mathrm{cou} 1 \mathrm{omb} / \mathrm{kg}$.

RWSF: Retrievable waste storage facility.

Scrubbers: An apparatus that chemically removes impurities from exhaust gas emissions.

Secondary Wastes: Wastes that result from applying waste treatment technologies to primary wastes.

Sedimentary Basin: A geologically depressed area that has thick sediments in the interior and thinner sediments at the edges.

Seismicity: The phenomenon of earth movements as manifested by earthquakes.

SFPF: Spent fuel packaging facility.

Shield: A continental segment of the earth's crust which has been relatively stable over a long period of time and which has exposed crystalline rocks mostly of Precambrian age; in general, representing the oldest rocks of the continent.

Shielding: A material interposed between a source of radiation and personnel for protection against the danger of radiation. Cormonly used shielding materials are concrete, water and lead.

Shipping Cask: A specially designed container used for shipping radioactive materials.

SHLW: Solidified high-level waste. 
Short-Lived Nuclides: Radioactive isotopes with relatively short half-lives. Usage for some isotopes varies with the concept being considered (e.g., isotopes with 5-50 year half-lives are short lived in the context of geologic disposal but long lived in the context of predisposal operations).

Slurry: A fluid mixture or suspension of insoluble material.

Solidification: Conversion of liquid radioactive waste to a dry, stable solid.

Source Terms: The quantity of radioactive material (or other pollutant) released to the environment at its point of release (source).

Spent Fuel (SF): Nuclear reactor fuel that has been used to the extent that it can no longer be used efficiently in a nuc lear power plant.

Stock: An igneous intrusion less than $100 \mathrm{~km}^{2}\left(40 \mathrm{mi}^{2}\right)$ in surface exposure.

Storage: Retention of waste in some type of manmade device in a manner permitting retrieval.

Strain: Deformation resulting from applied stress; proportional to stress.

Stratum: Sedimentary bed or layer, regardless of thickness, of homogeneous or gradational litho logy.

Syncline: A fold, the core of which contains stratigraphically younger rocks, and which, in simplest form, is elongate and concave upward with the two limbs dipping toward each other.

Tailings: The part of any ore that is regarded as too poor to be treated further.

Tails: In the case of uranium it refers to the depleted uranium left after enrichment operations.

TBR: Tributyl phosphate, a solvent used in the PUREX fuel reprocessing process.

Technologies: Specific methods for implementing concepts. An example is calcination of liquid high-level waste by using a spray calciner.

Tectonic: of, pertaining to, or designating the processes causing, and the rock structures resulting from, deformation of the earth's crust.

Tectonism (diastrophism): Crustal movement produced by earth forces, such as the formation of plateaus and mountain ranges; the structural behavior of an element of the earth's crust during, or between, major cycles of sedimentation.

Theoretical Density (TD): Maximum density attainable for any given material.

Thermal Regime: The area adjacent to a heat source which is affected by that source.

Trajectory: The curve that an object describes in space in traveling from one point to another.

Transmissivity: Volume of water flowing through a $1-\mathrm{ft}$ width of aquifer of given thickness under a unit gradient ( $1 \mathrm{ft}$ vertically for each $1 \mathrm{ft}$ laterally) and at the viscosity prevailing in the field. Mathematically, it is the product of permeability and aquifer thickness.

Transmutation: A nuclear process in which one nuclide is transformed into the nuclide of a different element. This can be accomplished by bombardment with neutrons or other nuclear particles. 
Transportation: Movement of materials between sites. Intra-site movement is not considered. Includes alternative methods for packaging, handling, and transport of waste materials and plutonium compounds. Concepts include all conventional methods of 1 and and water transport required by the waste management system.

Transuranic (TRU) elements: Elements with atomic number groater than 92. They include, among others, neptunium, plutonium, americium, and curium.

Transuranic Waste: Waste material measured or assumed to contain more than a specified concentration of transuranic elements. For purposes of this Statement, TRU waste is waste from locations that might cause contamination levels above 10 nanocuries of transuranic alpha activity per gram of waste.

Treatment: Operations intended to benefit safety or economy by changing the waste characteristics.

Uitramafic: Pertaining to igneous rocks composed chiefly of ferromagnesian dark minerals.

Up lift: A structurally high area in the crust, produced by movements that raise or upthrust the rocks, as in a dome or arch.

Vital Areas: The code of Federal Regulations (10 CFR 73), defines equipment items, systems, devices, and materials whose failure, destruction or release could directly endanger the public health and safety by exposure to radiation defined as "vital". Areas containing such items or materials (e.g., spent fuel or high-level waste) are defined as "vital" areas and subject to special protection measures.

Waste Immobilization: Process of converting waste to a stable, solid and relatively insolub le form.

Waste Isolation Pilot Plant (WIPP): A Defense repository proposed for a site in Southeastern New Mexico.

Waste Management: The planning, execution and surveillance of essential functions related to the control of radioactive (and nonradioactive) waste, including treatment, transportation, storage, surveillance, and isolation.

Water Table: The upper surface of the zone of water saturation in the subsurface, at which the pressure is equal to atmospheric pressure; the upper surface of an unconfined aquifer. 
APPENDIX B

COMPUTER CODE ARRAYF*

*Klett, R. D., Hertel, E. S., Molly, A. E., 1980. System Engineering Programs for Geologic Nuclear Waste Disposal, SAND80-0440, Sandia National Laboratories, Albuquerque, New Mexico, June. 
Finite Heat Generating Canisters With Effects of the Earth's Surface and Adjacent Cylinders

Two computer programs have been developed which solve analytical equations for the conduction of heat from spherical and cylindrical, exponentially decaying heat sources, through a uniform semi-infinite medium with one isothermal surface. The MUFTI program describes the temperature field around single spherical or finite length vertical heat sources a given distance below the isothermal surface. ARRAY is an extension of MUFTI which includes up to 10 heat sources in a plane parallel to the isothermal surface. Both programs are based on the work of J. Muft1 with the isothermal plane and adjacent heat sources added by using the method of superposition. An eight-point Gaussian quadrature technique developed by $D$. Amos is used to evaluate the equations. This technique is very rapid and inexpensive, making it well suited for systems studies. All thermophysical property, geometric, and time input data and all outputs are dimensionless, which makes it possible to analyze several geometries and surrounding media with each computer run by multiplying the output by several simple algebraic expressions.

Using the design sequence outlined in this report, the nuclear waste canister size and the disposal media are defined by using the TMAX series and modified by logistic, environmental, economic, manufacturing, and other constraints. Modified and extended versions of the MUFTI and ARRAY programs are used as inputs to the programs described in the next sections for repository optimization and for waste for sensitivity studies. For these applications, it is more convenient to input dimensional properties, geometries, and times, 
and have a dimensional output. In addition, most repositories have canisters, liners, and gas-filled annuli between the waste and the disposal media. The modifications to ARRAY described in this section add the dimensional input and output, simplify the input, add multiple canisters and gaps, allow for an annular waste configuration, add canisters in a vertical column, change the output format, and make MUFTI an option of ARRAY, to form a new program ARRAYF. The modifications are based on a single isolated canister or either of two canister arrays and two configurations. Figure B-1 shows the square and triangular (hexagonal close pack) layouts that would be used for geologic dry well and subseabed repositories. Figure B-2 is the configuration used to approximate a multilayered canister located a finite distance (D) from the earth's srface. Also shown are 10 preselected locations for temperature calculations. Figure B-3 is the configuration used to compute temperatures of up to 10 locations in the disposal medium. 
Square

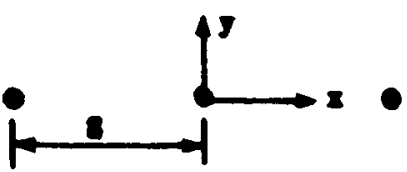

$\bullet$
Trienfular
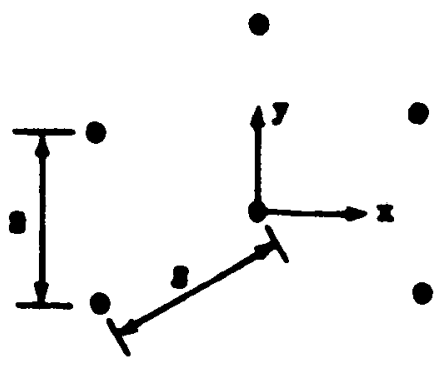

-

FIGURE B-1. CANISTER LAYOUTS FOR GEOLOGIC DRY WELL AND SUBSEABED REPOSITORIES

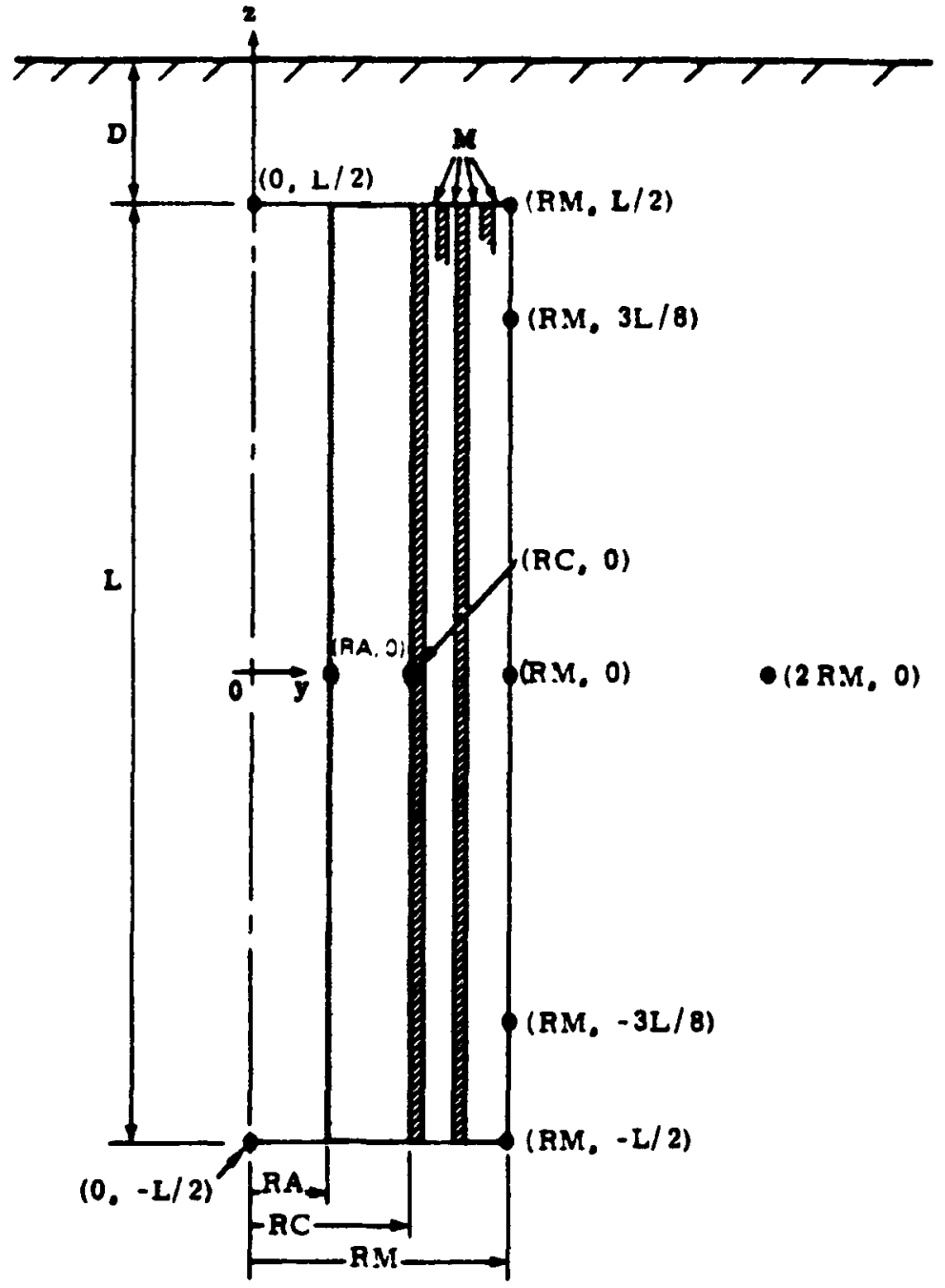

FIGURE B-2. VERTICAL FINITE CONCENTRIC WASTE CYLINDERS FILLED WITH AN ANNULAR HEAT SOURCE, BURIED A FINITE DISTANCE FROM THE EARTH'S SURFACE IN THE $x=0$ PLANE 


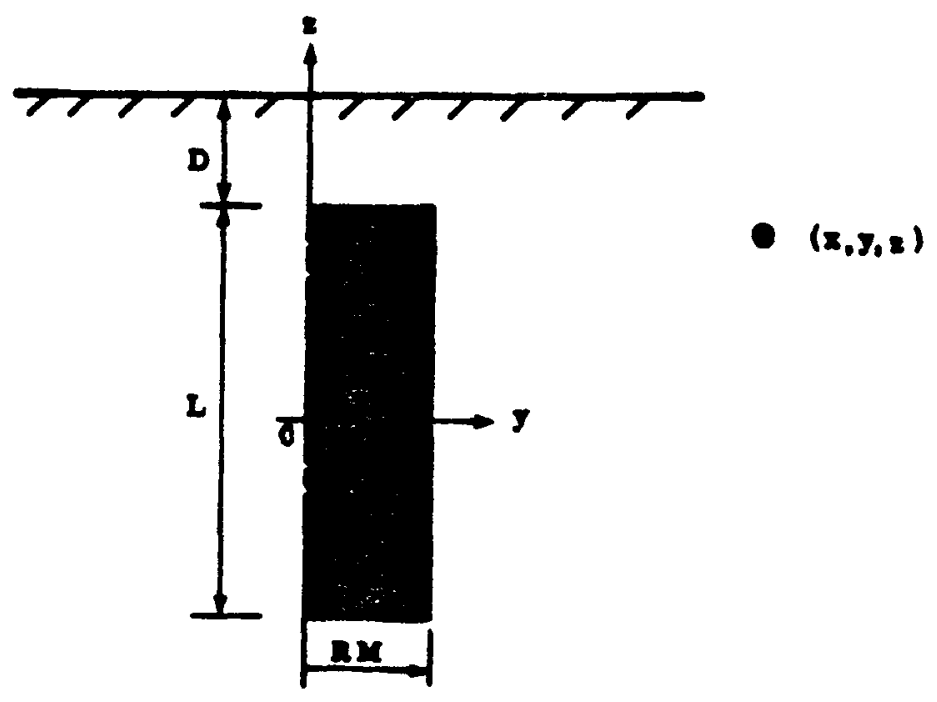

FIGURE B-3. VERTICAL FINITE CYLINDRICAL HEAT SOURCES BURIED A FINITE DISTANCE FROM THE EARTH'S SURFACE IN TRIANGULAR OR SQUARE ARRAYS 
-

- 


\section{DISTRIBUTION LIST}

ABAMA DEPT OF ENERGY

CAMERON MCDONALD

ALABAMA STATE GEOLOGICAL SURVEY THORNTON L NEATHERY

ALLIED GENERAL NUCLEAR SERVICES PF HIGHBERGER

$M$ A KOLB

ALLIS-CHALMERS

GARRICK J SOLOVEY

AMERICAN NUCLEAR INSURERS DOTTIE SHERMAN

ANALYSIS \& TECHNOLOGY INC $T$ MAZOUR

ANAIVTIC \& COMPUTATIONAL RESEARCH INC

B SAGAR

APPLIED MECHANICS INC JOHN R WILLIAMS

ARGONNE NATIONAL LABORATORY

SHERMAN M FRIED

WYMAN HARRISON

MARTIN SEITZ

MARTIN I STEINDLER

W S WHITE

ARINC RESEARCH CORP

H P HIMPLER

ARIZONA PUBLIC SERVICE COMMISSION

HENRY W RILEY, JR

ARTHUR D. LITTLE INC

AVIVA BRECHER

CHARLES R HADLOCK

ATKINS RESEARCH \& DEVELOPMENT

$T W$ BROYD

ATOMIC ENERGY CONTROL BOARD

I L WALLACH

ATOMIC ENERCY COUNCIL, ROC KUO-YUEH LIU

ATOMIC ENERGY OF CANADA LTO

MO LUKE

ANN QUINN

ATOMIC ENERGY RESEARCH ESTABLISHMENT

P ) BOURKE

R L NELSON

JOHN RAE

AUSTRALIAN ATOMIC ENERGY COMMISSION

BABCOCK \& WILCOX

INFORMATION SERVICES

BATTELLE COLUMBUS DIVISION

JOHNT MCCINNIS

STEPHEN NICOLOSI

THOMASM TRAINER

KENNETH R YATES

BECHTEL GROUP INC

THOMASS BAER

LESLIE I JARDINE

N A NORMAN

GERALD L PALAU

RICHARD I TOSETTI

BENDIX FIELD ENGINEERING CORP

BILL GRAHAM

CHARLES A JONES

IOHN C PACER

BLACK \& VEATCH

M JOHN ROBINSON

BOEING ENGINEERING AND CONSTRUCTION COMPANY

R B CAIRNS

Y SYSTEMPLANUNG

BRENK

BRITISH NUCLEAR FUELS LTD

R 5 WILKS
BROOKHAVEN NATIONAL LABORATORY

M S DAVIS

SANDRA G LANE

PETER SOO

HELEN TODOSOW (2)

BUNDESANSTALT FUR GEOWISSENSCHAFTEN

UND ROHSTOFFE

MICHAEL LANGER

HELMUT VENZLAFF

BUNDESMINISTERIUM FUR FORSCHUNC ROLF-PETER RANDL

BUREAU DE RECHERCHES GEOLOGIQUES ET MINIERES

PIERRE F PEAUDECERF

BURNS AND ROE INDUSTRIAL SERVICES CORP JOHN PIRRO

CALIFORNIA DEPT OF CONSERVATION

PERRY AMIMITO

CANYONLANDS NATIONAL PARK

PETER L PARRY

CAPITAL AREA GROUND WATER

CONSERVATION COMMISSION

A N TURCAN IR

CARNEGIE-MELLON UNIVERSITY

INDIRA NAIR

CASTUS VALLEY ORCHARDS

CARL ANDERSON

CAYUGA LAKE CONSERVATION

ASSOCIATION INC

D 5 KIEFER

CENTRE D ETUDE DE L ENERGIE NUCLEAIRE

RENE HEREMANS

CENTRE D INFORMATIQUE GEOLOGIQUE

GHISLAIN DE MARSILY

CONNECTICUT SITING COUNCIL

GLORIA DIBBLE POND

CONSOIL ASSOCIATES

DAVID A LEE

COPPE/UFRJ

LUIZ OLIVEIRA

CORNELL UNIVERSITY

JOHN BIRD

DUANE CHAPMAN

FRED H KULHAWY

CORTLAND COUNTY HEALTH DEPT

I $V$ FEUSS

COUNCIL ON ECONOMIC PRIORITIES

MARVIN RESNIKOFF

CYGNA ENERGY SERVICES

DONALD GARDNER

D.R.E.

KARL J ANANIA

DAMES \& MOORE

RON KEAR

O L OZTUNOLI

DAPPOLONIA CONSULTING ENGINEERS INC

LISA K DONOHUE

ABBY FORREST

PETER C KELSALL

CARL E SCHUBERT

DAWCON MANAGEMENT CONSULTING

SERVICE

DAVID A WEBSTER

DEPT OF THE ENVIRONMENT

F S FEATES

DIVISION OF ENVIRONMENTAL SAFETY

RESEARCH

HARUTO NAKAMURA

DMGA, IPT

C DINIS DA GAMA
DRAVO ENGINEERS AND CONSTRUCTORS KEN BEALL

DUKE UNIVERSITY

THOMAS DAVIS

E.R. JOHNSON ASSOCIATES INC

E R JOHNSON

EARTH SCIENCE AND ENGINEERING INC LOU BLANCK

EARTH TECHNOLOGY CORP

KENNETH L WILSON

EAST TENNESSEE STATE UNIVERSITY

MICHAEL R SMITH

EBASCO SERVICES INC

ZUBAIR SALEEM

RAYMOND H SHUM

ECOLOGY CENTER OF LOUISIANA

ROSS VINCENT

EDISON ELECTRIC INSTITUTE

R E L STANFORD

EDS NUCLEAR INC

C SUNDARARAJAN

EG \& G IDAHO INC

GEORGE B LEVIN

T H SMITH

ELECTRIC POWER RESEARCH INSTITUTE CHAIM BRAUN

ELSAM

ARNE PEDERSEN

EMBASSY OF THE UNITED STATES (SWEDEN) MAUD LI HAIJLEN-RYLANDER

ENERGY FUELS NUCLEAR INC

DON M PILLMORE

ENERGY INC

ENERGY RESEARCH GROUP INC MARC GOLDSMITH

ENERGY RESEARCH LABORATORY HITACHI INC

MAKOTO KIKUCHI

ENVIRONMENTAL POLICY INSTITUTE

DAVID M BERICK

ENVIRONMENIAL RESEARCH GROUP INC

PETER G COLLINS

ENVIROSPHERE COMPANY

ROGER C ANDERSON

BOB HAINES

ERIE COUNTY ENVIRONMENTAL

MANAGEMENT COUNCIL

JOAN P SCHMIDT

ERTEC WESTERN INC

KENNETH WILSON

EXXON NUCLEAR IDAHO COMPANY INC CARY WAYMIRE

F.B.A.B.

OTTO BROZEN

FENIX \& SCISSON INC

JOSE A MACHADO

CHARLENE SPARKMAN

FLORIDA DEPT OF ENVIRONMENTAL

REGULATION

HAMILTON OVEN

FLORIDA INSTITUTE OF TECHNOLOGY

JOSEPH A ANGELO, JR

FLUOR ADVANCED TECHNOLOGY DIVISION JOAN V MCCURRY

FLUOR ENGINEERS \& CONSTRUCTORS INC RAYMOND I DUGAL

FORD, BACON \& DAVIS UTAH INC

DARRELL H CARD

PRESTON H HUNTER

BURTON I THAMER 
FOSTER-MILLER ASSOCIATES INC NORBERT PAAS

GENERAL ATOMIC COMPANY

ROBERT J CAMPANA

H C CARNEY

MICHAEL STAMATELATOS

GENERAL COURT OF MASSACHUSETTS

TIMOTHY I BURKE

GENERAL ELECTRIC COMPANY

BRUCE HUTCHINS

GEOLOGICAL SURYEY OF CANADA

JEFFEREY HUME

LIBRARY

GEORGIA INSTITUTE OF TECHNOLOGY

MELVIN W CARTER

GEOFFREY G EICHHOLZ

ALFRED SCHNEIDER

GEOTECHNICAL ENGINEERS INC

RICHARD W TURNBULL

GEOTRONS

JAMES MERCER

GESELLSCHAFT F. STRAHLEN U.

UMWELTFORSCHUNG M.B.H.

WOLFGANG BODE

HERMANN GIES

HANS W LEVI

GIBBS \& HILL INC

ROBERT PRIETO

GILBERT/COMMONWEALTH

JERRY L ELLIS

GLOBAL MARINE INC

ROBERT F BAUER

GOLDER ASSOCIATES

ELIZABETH EISENHOOD

LAWRENCE A WHITE

GIC GEOLOGIC TESTING CONSULTANTS LTD JOHN F PICKENS

H \& R TECHNICAL ASSOCIATES INC WILLIAM R RHYNE

HAHN-MEITNER-INSTITUT FUR

KERNFORSCHUNG BERLIN

KLAUS ECKART MAASS

HANFORD ENGINEERING DEVELOPMENT

LABORATORY

ALBERT G BLASEWITZ

ROBERT EINZIGER

HARVARD UNIVERSITY

CHARLES W BURNHAM

DADE W MOELLER

HIRAM COLLEGE

JAMES W COWDEN

HOUGH-NORWOOD HEALTH CARE CENTER

GEORGE H BROWN, MD

IMPERIAL COLLEGE OF SCIENCE AND

TECHNOLOGY

B K ATKINSON

INSTITUT FUR TIEFLAGERUNG

WERNT BREWITZ

KLAUS KUHN

E R SOLTER

INSTITUTE OF GEOLOGICAL SCIENCES

NEIL A CHAPMAN

INTERA ENVIRONMENTAL CONSULTANTS INC

F I PEARSON, JR

LARRY RICKERTSEN

ROBERT WILEMS

INTERNATIONAL ATOMIC ENERGY AGENCY

EVERETT R IRISH

FRANK A OHARA
INTERNATIONAL. ENERGY ASSOCIATES LTD BLYTHE K LYONS

INTERNATIONAL ENGINEERING COMPANY INC

TERRY L STEINBORN

MAX ZASLAWSKY

INTERNATIONAL RESEARCH AND

EVALUATION

R DANFORD

IOWA STATE UNIVERSITY

RICHARD DANOFSKY

MARTIN C EDELSON

IRT CORP

I STOKES

J.F.T. AGAPITO \& ASSOCIATES INC MICHAEL P HARDY

IAPAN ATOMIC ENERGY RESEARCH INSTITUTE TARO ITO

JAY L. SMITH COMPANY INC JAYL SMITH

JGC CORPORAIION

MASAHIKO MAKINO

JOHNS HOPKINS UNIVERSITY

JARED L COHON

JOINT RESEARCH CENTRE

GIRARDI FRANCESCO

JORDAN GORRILL ASSOCIATES JOHN D TEWHEY

KAISER ENGINEERS INC

I S RITCHIE

KALAMAZOO COLLEGE

RALPH M DEAL

KANSAS DEPT OF HEALTH AND

ENVIRONMENT

GERALD W ALLEN

KANSAS STATE GEOLOGICAL SURVEY WILLIAM W HAMBLETON

KBS

LARS B NILSSON

KELLER WREATH ASSOCIATES

FRANK WREATH

KERNFORSCHUNGSZENTRUM KARLSRUHE

GMBH

$K$ D CLOSS

R KOSTER

KIHN ASSOCIATES

HARRY KIHN

KLM ENGINEERING INC

B GEORGE KNIAZEWYCZ

KYOTO UNIVERSITY

YORITERU INOUE

LANCASTER AVENUE LIBRARY

FM CALVARESI

LAWRENCE BERKELEY LABORATORY

JOHN A APPS

THOMAS DOE

NORMANM EDELSTEIN

BRIAN KANEHIRO

I WANG

LAWRENCE LIVERMORE NATIONAL

LABORATORY

JOHN H CAMPBELL

HUGH HEARD

D D JACKSON

R CARROLL MANINGER

PAUL L PHELPS

FRANK ROGUE

W G SUTCLIFFE

TECHNICAL INFORMATION DEPARTMENT L-53

RICHARD VAN KONYNENBURC
IOS ALAMOS NATIONAL LABORATORY

ERNEST A BRYANT

GEORGE A COWAN

B CROWE

BRUCE R ERDAL

WAYNE R HANSEN

CLAUDE HERRICK

K K S PILLAY

JOHN T WHETTEN

KURT WOLFSBERG

LOS ALAMOS TECHNICAL ASSOCIATES INC HELEN F GRAM

R J KINGSBURY

LOUISIANA GEOLOGICAL SURVEY

LEE W JENNINGS

LOUISIANA STATE UNIVERSITY

EDWIN I NEWCHURCH

LOUISIANA TECH UNIVERSITY

LIBRARY

NORMAN WITRIAL

LOWENSTEIN, NEWMAN, REIS \& AXELRAD

MICHAEL A BAUSER

MASSACHUSETTS INSTITUTE OF

TECHNOLOGY

JOHN DEUTCH

TED GREENWOOD

RICHARD K LESTER

MARSHA LEVINE

MCMASTER UNIVERSITY

L W SHEMILT

MECHANICAL TECHNOLOGY INC

WARREN BESSLER

STANLEY W DOROFF

MEMBERS OF THE GENERAL PUBLIC

$W$ VON BLACK

DAVID H BOLTZ

JAMES BOYD

DANNELLE D DUDEK

DOROTHY FORD

RICHARD L FOUKE

STEVE FRISHMAN

SHIRLEY M GIFFORD

KENNETH GUSCOTT

C F HAJEK

THOMAS H LANGEVIN

D C LANCSTAFF

GRANT W LAPIER

DAVID LYLE

A ALAN MOGHISSI

JAMES B MUCKERHEIDE

ALAN D PASTERNAK

SHAILER S PHILBRICK

MARTIN RATHKE

HARRY W SMEDES

M J SZULINSKI

ROBERT WEESE

JIMMY L WHITE

ALEKSANDR $\vee$ ZOBKOV

MICHAEL BAKER, JR INC

C I TOUHILL

MICHIGAN DEPT OF PUBLIC HEALTH

DON VAN FAROWE

MICHIGAN DISTRICT HEALTH DEPT NO \& EDGAR KREFT

MICHIGAN LEGISLATIVE OFFICE OF SCIENCE

ADVISOR

MICHICAN TECHNOLOGICAL UNIVERSITY

GARY L DOWNEY

MINNESOTA GEOLOGICAL SURVEY

MATT S WALTON

MISSISSIPPI CITIZENS AGAINST NUCLEAR

DiSPOSAL

STANIEY DEAN FLINT 
MISSISSIPPI DEPT OF ENERGY AND

IRANSPORTATION

JOHN W GREEN (3)

SSISSIPPI DEPT OF NATURAL RESOURCES

CHARLES L BLALOCK

MISSISSIPPI DEPT OF WILDLIFE

CONSERVATION

JOSEPH W JACOB, JR

MISSISSIPPI EMERGENCY MANAGEMENT

AGENCY

JAMES E MAHER

MISSISSIPPI STATE BOARD OF HEALTH

EDDIE S FUENTE

I WARREN GREEN

MISSISSIPPI STATE HOUSE OF

REPRESENTATIVES

JERRY OKEEFE

MITRE CORP

LESTER A ETTLINGER

MOBAY CHEMICAL CORP

KENNETH H HASHIMOTO

NASA JOHNSON SPACE CENTER MICHAEL R HELFERT

NATIONAL ACADEMY OF SCIENCES JOHN T HOLLOWAY PETER B MYERS

NATIONAL BOARD FOR SPENT NUCLEAR

FUEL, KARNBRANSLENAMDEN NILS RYDELL

NATIONAL BUREAU OF STANDARDS WILLIAM P REED

NATIONAL OCEANOGRAPHIC AND

ATMOSPHERIC ADMINISTRATION

JACK SCHUMAN

NATIONALE GENOSSENSCHAFT FUR DIE

LAGERUNG RADIOAKTIVER ABFALLE MARLIES KUHN

NATURAL RESOURCES DEFENSE COUNCIL THOMAS B COCHRAN

NEW ENGLAND NUCLEAR CORP

KERRY BENNERT

NEW JERSEY DEPT OF ENVIRONMENTAL

PROTECTION

JEANETTE ENG

NEW MEXICO ENERGY AND MINERALS DEPT NEW MEXICO ENVIRONMENTAL EVALUATION GROUP

ROBERT H NEILL

NEW YORK DEPT OF HEALTH

DAVID AXELROD,M D

NEW YORK STATE ENERGY OFFICE

JOHN P SPATH (15)

NEW YORK STATE ENVIRONMENTAL

FACILITIES CORP

PICKETT T SIMPSON

NEW YORK STATE ERDA

JOHN C DEMPSEY

NEW YORK STATE GEOLOGICAL SURVEY

ROBERT H FAKUNDINY

NEW YORK STATE PUBLIC SERVICE

COMMISSION

FRED HAAG

NTR GOVERNMENT SERVICES

THOMAS $\checkmark$ REYNOLDS

NUCLEAR ASSURANCE CORP

ANDREW I FRANKEL

JEAN RION

NUCLEAR SAFETY RESEARCH ASSOCIATION

KAZUMORI MATSUO

NUS CORP

$G$ BELTER

DNEY I DAVIS
JOSEPH I DINUNNO

BARRY N NAFT

DOUGLAS D ORVIS

NUTECH ENGINEERS INC

PAUL C SUN

NWT CORP

W L PEARL

OAK RIDGE NATIONAL LABORATORY

CARLOS E BAMBERGER

J O BLOMEKE

H C CLAIBORNE

ALLEN G CROFF

LESLIE R DOLE

JOHN T ENSMINGER

CATHY S FORE

DAVID C KOCHER

ELLEN D SMITH

OFFICE OF NWTS INTECRATION

ROBERT E HEINEMAN

OHIO ENVIRONMENTAL COUNCIL

STEPHEN H SEDAM

OHIO STATE UNIVERSITY

M A CORNWELL

ONTARIO HYDRO

$R$ W BARNES

$R$ C OBERTH

OREGON DEPT OF ENERGY

DONALD W GODARD

MICHAEL W GRAINEY

OREGON STATE UNIVERSITY

U C RINGLE

ORGANIZATION FOR ECONOMIC

COOPERATION AND DEVELOPMENT

I P OLIVIER

OTHA INC

JOSEPH A LIEBERMAN

PACIFIC NORTHWEST LABORATORY

DON I BRADLEY

H C BURKHOLDER

JOHN B BURNHAM

L L CLARK

HARVEY DOVE

ORVILLE F HILL

I H JARRETT

MAXR KREITER

ROBERT MCCALLUM

R D NELSON

$R$ WILLIAM NELSON

R E NICHTINGALE

J M RUSIN

$R$ JEFF SERNE

PARSONS, BRINCKERHOFF, QUADE, \&

DOUGLAS, INC.

$T$ R KUESEL

PENNSYLVANIA GOVERNORS ENERGY

COUNCIL.

HERBERT JACOBS

PENNSYLVANIA OFFICE OF VOCATIONAL

REHABILITATION

ANDREW CHOPAK

PERRY COUNTY BOARD OF SUPERVISORS

PAUL D JOHNSTON,SR

PERRY COUNTY SCHOOLS

MANIEL A COCHRAN

PHYSIKALISCH-TECHNISCHE BUNDESANSTALT PETER BRENNECKE

PORTLAND GENERAL ELECTRIC

I W LENTSCH

POTASH CORP OF SASKATCHEWAN

GRAEME G STRATHDEE

POWER AUTHORITY OF THE STATE OF NEW YORK

MYRON M KACZMARSKY
POWER REACTOR AND NUCLEAR FUEL

DEVELOPMENT CORPORATION

PRINCETON UNIVERSITY

PETER MONTAGUE

PROCESS AND ENGINEERING DEVELOPMENT GERALD L RITTER

PUBLIC SERVICE INDIANA

ROBERT S WEGENG

PURDUE UNIVERSITY

PAUL S LYKOUDIS

QUADREX CORP

FRANCIS I KENESHEA

RADIATION PROTECTION COUNCIL

TERI L VIERIMA

RALPH M. PARSONS COMPANY

JERROLD A HAGEL

RE/SPEC INC

PAUL F GNIRK

RENSSELAER POLYTECHNIC INSTITUTE

JAMES WU

RESOURCE SYSTEMS INSTITUTE

KIRK R SMITH

RICHTON CITY HALL

R RAHAIM

RIDIHALGH, EGGERS \& ASSOCIATES INC PHILIP E EGGERS

ROCKWELL HANFORD OPERATIONS

RONALD C ARNETT

HARRY BABAD

R A DEJU

GEORGE C EVANS (2)

L. R FITCH

R J GIMERA

K THIRUMALAI

DAVE A TURNER

ROCKWELL INTERNATIONAL ENERGY SYSTEMS

GROUP

W S BENNETT

LAWRENCE J SMITH

ROGERS \& ASSOCIATES ENGINEERING CORP ARTHUR SUTHERLAND

ROYAL INSTITUTE OF TECHNOLOCY IVARS NEREINIEKS ROCER THUNVIK

S.E. LOGAN \& ASSOCIATES INC STANLEY E LOGAN

S.M. STOLLER CORP ROBERT W KUPP

SAN DIEGO GAS \& ELECTRIC COMPANY LOUIS BERNATH

SAN JOSE STATE UNIVERSITY SCHOOL OF ENGINEERING

$R N$ ANDERSON

SANDIA NATIONAL LABORATORIES

G C ALLEN

C L CHRISTENSEN

JOE A FERNANDEZ

NANCY C FINLEY

$R$ L HUNTER

THOMAS O HUNTER

I KEITH JOHNSTONE

R W LYNCH

MARTIN A MOLECKE

ANTHONY MULLER

IAMES T NEAL

RICHARD E PEPPINC

G F RUDOLFO

ALLAN R SATTLER

SCOTT SINNOCK

A W SNYDER

A E STEPHENSON

DANIEL M TALBERT 
LYNN D TYLER

WENDELL D WEART

WIPP CENTRAL FILES

SAVANNAH RIVER LABORATORY

E I HENNELLY

WILLIAM R MCDONELL

$S$ W OREAR SR

DONALD ORTH

SCIENCE APPLICATIONS INC

JEFFREY ARBITAL

JERRY I COHEN

RALPH FULLLWOOD

JAMES E HAMMELMAN

DEAN C KAUL

I ROBERT LARIVIERE

DAVID H LESTER

PETER E MCGRATH

JOHN E MOSIER

HOWARD PRATT

KRISHAN K WAHI

ROBERT A YODER

SENECA COUNTY PLANNING BOARD

SHIMIZU CONSTRUCTION COMPANY LTD

TAKASHI ISHII

JUNJI TAKAGI

SIERRA CLUB - MISSISSIPPI CHAPTER

SIERRA GEOPHYSICS INC

STEPHEN L GILLETT

SOUTH DAKOTA OFFICE OF ENERGY POLICY

STEVEN M WECMAN

SOUTHERN SCIENCE APPLICATIONS INC

K D KIRBY

SOUTHWEST RESEARCH AND INFORMATION

CENTER

ALISON P MONROE

ST BONAVENTURE UNIVERSITY

CARL I TWAROG

ST JOSEPH COLLEGE

CLAIRE MARKHAM

ST MARTIN HIGH SCHOOL

RAYMOND I WERTHNER

STANFORD UNIVERSITY

KONRAD B KRAUSKOPF

IRWIN REMSON

STEARNS-ROGER SERVICES INC

VERYL ESCHEN

STONE \& WEBSTER ENGINEERING CORP

J PECK

ARLENE C POST

SUMMIT COUNTY ENVIRONMENTAL SERVICES JAMES T KING

SWISS FEDERAL OFFICE OF ENERGY

U NIEDERER

SYRACUSE UNIVERSITY

WALTER MEYER

SYSTEM DEVELOPMENT CORP

RICHARD BALSAM

H G DAVIS

RHONNIE L SMITH

SYSTEMS SCIENCE AND SOFTWARE PETER LAGUS

T.M. GATES INC

TODD M GATES

TECHNICAL INFORMATION PROIECT DONALD PAY

TECHNICAL RESEARCH CENTRE OF FINLAND

OLLI J HEINONEN

SILJA RUMMUKAINEN

KARI SAARI

SEPPO VUORI

TEKNEKRON RESEARCH INC

ANTHONY F MOSCATI
TENNESSEE DEPT OF PUBLIC HEALTH

BILL GRAHAM

TERA CORP

LAWRENCE H WIGHT

TERRA TEK INC

RICHARD LINGLE

TEXAS A\&M UNIVERSITY

JOHN HANDIN

ROY W HANN, IR

STEVE MURDOCK

GARY ROBBINS

JAMES E RUSSELL.

TEXAS BUREAU OF RADIATION CONTROL DONALD G ANDERSON

TEXAS DEPT OF HEALTH

DAVID K LACKER

TEXAS ENERGY \& NATURAL RESOURCES

ADVISORY COUNCIL

TERRY BARRON

CAROL KING

TEXAS HOUSE OF REPRESENTATIVES PETE LANEY

THE ANALYTIC SCIENCES CORP

JOHN W BARTLETT

CHARLES $M$ KOPLIK

I $W$ VOSS

THE CLARION-LEDGER

MARK SCHLEIFSTEIN

TRENDS PUBLISHING INC

TRW INC

PETER ALEXANDER

E R CHRISTIE

TUN ISMAIL ATOMIC RESEARCH CENTRE PUSPAT! LIBRARY

TVO POWER COMPANY

VEIJO RYHANEN

U.H.D.E.

FRANK STEINBRUNN

U.K. DEPT. OF THE ENVIRONMENT

RADIOACTIVE WASTE MANAGEMENT DIVISION

U.S. ARMY CORPS OF ENGINEERS

ALAN BUCK

U.S. BUREAU OF LAND MANAGEMENT EDWARD R SCHERICK

U.S. BUREAU OF MINES

GEORGE E NIEWIADOMSKI

U.S. DEPT OF ENERGY - ALBUQUERQUE

OPERATIONS OFFICE

R LOWERY

JOSEPH M MCGOUGH

U.S. DEPT OF ENERGY - ASSISTANT GENERAL

COUNSEL FOR ENVIRONMENT

S H GREENLEIGH

U.S. DEPT OF ENERGY - CHICAGO

OPERATIONS OFFICE

D BRAY

DUANE DAY

PUBLIC READING ROOM

R SELBY

U.S. DEPT OF ENERGY - DALLAS SUPPORT

OFFICE

CURTISE CARLSON, JR

U.S. DEPT OF ENERGY - DIVISION OF WASTE

REPOSITORY DEPLOYMENT

W WADE BALLARD, JR

I W BENNETT

C R COOLEY (2)

WARREN EISTER

MARK W FREI

THOMAS P LONGO

RALPH STEIN
U.S. DEPT OF ENERGY - HEADQUARTERS

PUBLIC READINC ROOM

U.S. DEPT OF ENERGY - IDAHO OPERATIONS OFFICE

JAMES F LEONARD

CARL R ROBERTSON

PUBLIC READING ROOM

J H SAKO

JOHN B WHITSETT

U.S. DEPT OF ENERGY - NEVADA OPERATIONS OFFICE

$M P$ KUNICH

PUBLIC READING ROOM

U.S. DEPT OF ENERGY - NUCLEAR

ENVIRONMENTAL APPLICATION BRANCH ROBERT W BARBER

U.S. DEPT OF ENERGY - NUCLEAR WASTE

MANAGEMENT AND FUEL CYCLE PROGRAMS EDWARD F MASTAL

U.S. DEPT OF ENERGY - NWTS PROGRAM

OFFICE

T BAILLIEUL

$M$ BLANCHARD

$\perp$ A CASEY

R LAHOTI

L K MCCLAIN

J O NEFF

K K WU

R C WUNDERLICH

U.S. DEPT OF ENERGY - OAK RIDGE

OPERATIONS OFFICE

PUBLIC READING ROOM

U.S. DEPT OF ENERGY - OFFICE OF NUCLEAR

WASTE MANAGEMENT

EARL WAHLQUIST

U.S. DEPT OF ENERGY - OFFICE OF PROJECT AND FACILITIES MANAGEMENT

D L HARTMAN

U.S. DEPT OF ENERGY - OFFICE OF WASTE

ISOLATION

JOSEPH A LEARY

JANIE SHAHEEN

U.S. DEPT OF ENERGY - OFFICE OF WASTE

PRODUCTS

JAMES TURI

U.S. DEPT OF ENERGY - RICHLAND

OPERATIONS OFFICE

O L OLSON

PUBLIC READING ROOM

I SCHREIBER

U.S. DEPT OF ENERGY - SAN FRANCISCO

OPERATIONS OFFICE

ENERGY RESOURCES CENTER

PUBLIC READING ROOM

U.S. DEPT OF ENERGY - SAVANNAH RIVER

OPERATIONS OFFICE

REGINA T HARRIS

$T$ B HINDMAN

U.S. DEPT OF ENERGY - TECHNICAL

INFORMATION CENTER (27)

U.S. ENVIRONMENTAL PROTECTION AGENCY DIVISION OF CRITERIA \& STANDARDS

JAMES NEIHEISEL

U.S. GEOLOGICAL SURVEY - COLUMBUS

A M LA SALA, IR

U.S. GEOLOGICAL SURVEY - DENYER

JESS M CLEVELAND

W SCOTT KEYS

U.S. GEOLOGICAL SURVEY - MENLO PARK

JOHN BREDEHOEYT

JACOB RUBIN 
U.S. GEOLOGICAL SURVEY - RESTON IOHN ROBERTSON

EUCENE H. ROSEBOOM IR

PETER R. STEVENS

DAVID B. STEWART

NEWELL J. TRASK IR

U.S. HOUSE SUBCOMMITTEE ON ENERGY AND

THE ENVIRONMENT

MORRIS K. UDALL

U.S. NUCLEAR REGULATORY COMMISSION

J. CALVIN BELOTE

PATRICIA A. COMELLA

ENRICO F. CONTI

MICHAEL C. CULLINGFORD

J. J. DAVIS

F. L. DOYLE

FREDERICK FORSCHER

RICHARD F. FOSTER

PAUL F. GOLDBERC

HIGH-LEVEL WASTE LICENSING BRANCH

HIGH-LEVEL WASTE TECHNICAL

CLYDE JUPITER

MICHAEL S. KEARNEY

LINDA L. LEHMAN

LIBRARY

JAMES C. MALARO

IOHN B. MARTIN (3)

JOHN C. MCKINLEY

HUBERT MILLER

EDWARD ODONNELL

R. JOHN STARMER

U.S. SENATE COMMITTEE ON ENERGY AND

NATURAL RESOURCES

WILLIS D. SMITH

U.W. - MILWAUKEE SARUP

LYNNE B. JUDD

UHDE GMBH

OLINGER

UNION CARBIDE CORP

BLYNN E. PRINCE

UNION OF CONCERNED SCIENTISTS

MICHAEL FADEN

GORDON THOMPSON

UNIVERSITY OF ALBERTA

F.W. SCHWARTZ

UNIVERSITY OF ARIZONA

JAAK DAEMEN

IAMES G. MCCRAY

ROY G. POST
UNIVERSITY OF CALIFORNIA AT BERKELEY TODD LAPORTE

THOMAS H. PIGFORD

UNIVERSITY OF CALIFORNIA AT LOS ANGELES D. OKRENT

UNIVERSITY OF CALIFORNIA AT SAN DIEGO RICHARD J. WILLIS

UNIVERSITY OF CALIFORNIA AT SANTA CRUZ JOEL PRIMACK

UNIVERSITY OF DELAWARE

FRANK A. KULACKI

UNIVERSITY OF FLORIDA

DAVID E. CLARK

DOLORES C. JENKINS

M. J. OHANIAN

UNIVERSITY OF ILLINOIS AT URBANA -

CHAMPAIGN

DANIEL F. HANG

ALBERT J. MACHIELS

MAGDI RAGHEB

UNIVERSITY OF LOWELL

JAMES R. SHEFF

UNIVERSITY OF MICHIGAN

RICHARD C. PORTER

UNIVERSITY OF MISSOURI AT ROLLA

ARVIND KUMAR

UNIVERSITY OF OKLAHOMA

DANIEL T. BOATRIGHT

UNIVERSITY OF OTTAWA

TUNCER OREN

UNIVERSITY OF SOUTHERN MISSISSIPPI

IAMES W. PINSON

UNIVERSITY OF TENNESSEE AT KNOXVILLE

J.B. FUSSELL

UNIVERSITY OF TEXAS AT AUSTIN

JOE D. LEDBETTER

UNIVERSITY OF TEXAS AT SAN ANTONIO

DONALD R. LEWIS

UNIVERSITY OF TOKYO

RYOMEI KIYOSE

UNIVERSITY OF UTAH

GARY M. SANDQUIST

UNIVERSITY OF UTAH RESEARCH INSTITUTE

DUNCAN FOLEY

UNIVERSITY OF WASHINGTON

DAVID BODANSKY

M. A. ROBKIN

UNIVERSITY OF WESTERN ONTARIO

WILLIAM S. FYLE
URS/JOHN A. BLUME \& ASSOCIATES,

ENGINEERS

ANDREW B. CUNNINGHAM

UTAH BUREAU OF RADIATION CONTROL DARRELL M. WARREN

UTAH GEOLOGICAL AND MINERAL SURVEY MAGE YONETANI

UTAH SOUTHEASTERN DISTRICI HEALTH

DEPARTMENT

ROBERT L. FURLOW

UTILITY DATA INSTITUTE

FRED YOST

VANDERBILT UNIVERSITY

FRANK L. PARKER

VERMONT AGENCY OF ENVIRONMENTAL

CONSERVATION

CHARLES A. RATTE

VERMONT STATE NUCLEAR ADVISORY PANEL VIRGINIA CALLAN

VIRGINIA DEPT OF HEALTH ROBERT G. WICKLINE

WASHINGTON HOUSE OF REPRESENTATIVES RAY ISAACSON

WATTLAB

BOB E. WATT

WAYNE STATE UNIVERSITY

JAMES A. WOODYARD

WEST DADE REGIONAL LIBRARY

LOURDES BLANCO LOPEZ

WEST VALLEY NUCLEAR SERVICES COMPANY INC

RICHARD M. WINAR

WESTINGHOUSE ELECTRIC CORP

GEORGE V. B. HALL

D. NEWBY

JAMES H. SALING

WISCONSIN DEPT OF NATURAL RESOURCES DUWAYNE F. GEBKEN

WISCONSIN DIVISION OF STATE ENERGY

ROBERT HALSTEAD

WISCONSIN GEOLOGICAL AND NATURAL.

HISTORY SURVEY

MICHAEL G. MUDREY, JR.

MEREDITH E. OSTROM

WISCONSIN PUBLIC SERVICE CORP

PAUL WOZNIAK

WOODS ROBERTSON ASSOCIATES

WOODWARD-CIYDE CONSULTANTS

ASHOK PATWARDHAN

WYOMING GEOLOGICAL SURVEY

DANIEL N. MILLER 